\title{
Heloisa Hanada
}

\section{Os psicólogos e a assistência a mulheres em situação de violência}

Dissertação apresentada à Faculdade de Medicina da Universidade de São Paulo para obtenção de título de Mestre em Ciências

Área de concentração: Medicina Preventiva Orientadora: Ana Flávia Pires Lucas D'Oliveira

São Paulo 
Dados Internacionais de Catalogação na Publicação (CIP)

Preparada pela Biblioteca da

Faculdade de Medicina da Universidade de São Paulo

Creprodução autorizada pelo autor

Hanada, Heloisa

Os psicólogos e a assistência a mulheres em situação de violência / Heloisa

Hanada. -- São Paulo, 2007.

Dissertação(mestrado)--Faculdade de Medicina da Universidade de São Paulo.

' Departamento de Medicina Preventiva.

Area de concentração: Medicina Preventiva.

Orientadora: Ana Flávia Pires Lucas D’Oliveira

Descritores: 1.Violência contra a mulher 2.Psicólogos 3.Relações interprofissionais 4.Redes comunitárias

USP/FM/SBD-460/07 


\section{RESUMO}

Hanada, H. Os psicólogos e a assistência a mulheres em situação de violência. [dissertação]. São Paulo: Faculdade de Medicina, Universidade de São Paulo; 2007.

O presente estudo buscou identificar e analisar a inserção do psicólogo na assistência a mulheres em situação de violência, na rede de serviços específicos da região metropolitana de São Paulo. A partir da perspectiva da necessidade de ações multiprofissionais e intersetoriais no enfrentamento e atenção às situações de violência de gênero, estudou-se como a assistência psicológica é organizada em serviços de diversas vocações assistenciais e como suas ações são articuladas com outros profissionais e outros serviços. Para tanto, foram levantados documentos normativos para a assistência (Ministério da Saúde e Secretaria Especial de Políticas para as Mulheres) e foram analisadas informações obtidas em entrevistas com profissionais de 109 serviços paulistas de diversas vocações assistenciais (policial, jurídico, saúde, psicossocial, abrigos, orientações básicas). Os psicólogos estavam presentes e foram solicitados em todos os tipos de serviços, com menor participação nos serviços policiais e jurídicos. Tiveram inserção tanto na capacitação e supervisão dos profissionais em geral, como no atendimento direto à clientela dos serviços. $\mathrm{Na}$ assistência, notou-se grande diversidade de práticas - atividades clínicas, educativas, de orientação, mediação jurídica, sendo freqüente o ajustamento destas intervenções aos objetivos e cultura hierárquica de cada categoria de serviço. No geral, os psicólogos eram chamados para atuar no fortalecimento da auto-estima, retomada da vida sexual, reestruturação da vida, elaboração da situação de violência, elaboração e saída da condição de vitimização, promoção de autonomia e busca de transformação dos padrões de relacionamento familiar/ conjugal ou de gênero. Esses objetivos estavam postos para as equipes dos serviços em geral, especialmente o primeiro. $\mathrm{Na}$ formulação dos objetivos dos serviços e do formato das atividades propostas percebeu-se influência de concepções e propostas assistenciais do movimento de mulheres. Observou-se que nem sempre havia distinção clara entre o trabalho do psicólogo e de outros profissionais, principalmente com relação ao trabalho do assistente social, resultando em indefinição de funções e ações. Esta indefinição poderia representar dificuldades no diálogo entre profissionais e entre serviços e na articulação de ações multiprofissional, o que comprometeria a atenção integral às mulheres em situação de violência. Por outro lado, essa indefinição pareceu possibilitar inovações na prática assistencial. Observou-se também que a articulação multiprofissional foi buscada, em geral, no interior das equipes dos próprios serviços, mas em alguns os profissionais buscaram a complementariedade de suas ações pela articulação com serviços de outras vocações assistenciais. Levantou-se a necessidade de melhores definições sobre a assistência psicológica voltada para mulheres em situação de violência, em relação ao trabalho especifico do psicólogo na rede especializada e na rede geral de atenção de São Paulo.

Descritores: Violência contra a mulher; Psicólogos; Relações interprofissionais; Redes comunitárias. 


\section{SUMMARY}

Hanada, H. Psychological assistance and violence against women. [dissertation]. São Paulo: "Faculdade de Medicina, Universidade de São Paulo"; 2007.

The aim of the present investigation was to identify and analyse the insertion of psychologists working in the network of services for assisting women experiencing violence in the metropolitan region of Sao Paulo. The organization of psychological assistance in diverse assistance vocations and the integration of psychologists in work teams and in other services were studied from the perspective of women's needs, and multi-professional and intersectoral actions in facing the situations and providing care for gender-based violence. For that, normative documents on violence care were researched (Ministry of Health and Department of Special Policy for Women) and data from interviews with professionals working in 109 services with diverse assistance vocations in Sao Paulo (police, justice, health, psychosocial assistance, shelters, basic assistance) were analysed. Psychologists are present and their work is requested in all types of services, but with less participation in police and justice facilities. They work in the training and supervision of other professionals, as well as directly assisting the public. A great diversity of practices was observed in the assistance - clinical, educational, orientation and judicial mediation activities - with frequent adjustment of these interventions to the objectives and hierarchical culture within each category of service. In general, psychologists are called to work in the strengthening of self-esteem, the resuming of sexual life, restructuring life itself, understanding of the situation of violence, working-out of and escape from the victim condition, promotion of autonomy and search for transformation in family/ intimate relationships or gender patterns. These objectives are put to the general teams working in the services, especially the first one. The influence of conceptions and proposals from the women's movement is perceived in the formulation of the services' objectives and in the way the activities are developed. The distinction between the psychologists' work and the work of other professionals is not always clear, especially regarding social work. This results in imprecise functions and actions, which may represent difficulties in the dialogue between professionals and services, and in the integration of multi-professional actions, potentially compromising integral care to women experiencing violence. On the other hand, this impreciseness opens up space for innovations in assistance practices. Multi-professional integration is, in general, also sought within work teams of each service, but in some of them the professionals search for complementarity in their actions and integration with services with different assistance vocations. There is a need for better definitions on the specific role of psychologists in the assistance of women experiencing violence, considering the specific network and the broader assistance network in Sao Paulo.

Descriptors: violence against women; psychologists; interprofessional relations; community network. 


\section{Agradecimentos}

Ao Cnpq, pelo financiamento que possibilitou a realização deste estudo.

Ao Ministério da Justiça, que financiou a pesquisa "Identificando Possibilidades e Limites do Trabalho em Rede para a Redução da Violência contra a Mulher: estudo entre três capitais brasileiras", que foi base para o presente estudo.

À prof ${ }^{a}$ Ana Flávia D’Oliveira, pelo rigor, paciência e carinho com que me orientou neste trabalho.

À prof ${ }^{a}$ Lilia Blima Schraiber, por ter me apresentado ao tema e ter me orientado nos primeiros passos de pesquisa em saúde. Também pelo estímulo para que prosseguisse no trabalho acadêmico.

Às duas, pelos exemplos de sabedoria e ética no trabalho de pesquisa e de intervenções em serviços.

Às prof ${ }^{\mathrm{as}}$ Márcia Couto, Lygia França e Maria Inês Battistella Nemes, pela leitura atenta e pelas sugestões feitas por ocasião do exame de qualificação.

Aos colegas e amigos do Grupo de Pesquisa "Violência e Gênero nas Práticas de Saúde”, Márcia, Wagner, Ligia, Júlia e Tarcísio, pela convivência enriquecedora, incentivo e apoio para esta dissertação e em todos os trabalhos coletivos.

Aos serviços e profissionais participantes da pesquisa "Identificando Possibilidades e Limites do Trabalho em Rede para a Redução da Violência contra a Mulher: estudo entre três capitais brasileiras", pela disponibilidade e informações fornecidas, sem as quais o atual estudo não seria possível.

Aos entrevistadores Ana Paula, Gisele, Iara, Ivanilde, Josiane, Juliana, Julio, Maria José, Marcos, Stella e Roseli, pelo trabalho conjunto na realização do campo de São Paulo. À Simone e Valéria, que dividiram comigo o trabalho de supervisão de campo.

À Lílian e Ricardo, pelo atencioso e eficiente apoio de secretaria.

À Ligia Kiss, pela tradução para o inglês dos resumos dessa dissertação.

À Shiro Hanada, pela colaboração na revisão do texto.

À minha família, especialmente meus pais, pelo apoio e incentivo em todos os momentos.

Aos amigos, especialmente Jaqueline, Eliane, Ane, Ana Cláudia e Marcelo, que de alguma forma, participaram e contribuíram com este trabalho. 
Esta dissertação está de acordo com as seguintes normas, em vigor no momento desta publicação:

Referências: adaptado de International Committee of Medical Journals Editors (Vancouver)

Universidade de São Paulo. Faculdade de Medicina. Serviço de Biblioteca e Documentação. Guia de apresentação de dissertações, teses e monografias. Elaborado por Anneliese Carneiro da Cunha, Maria Julia de A.L.Freddi, Maria F. Crestana, Marinalva de Souza Aragão, Suely campos Cardoso, Valeria Vilhena. $2^{\text {a }}$ ed. São Paulo: Serviço de biblioteca e Documentação; 2005.

Abreviaturas dos títulos dos periódicos de acordo com List of Journals Indexed in Index Medicus. 


\section{SUMÁRIO}

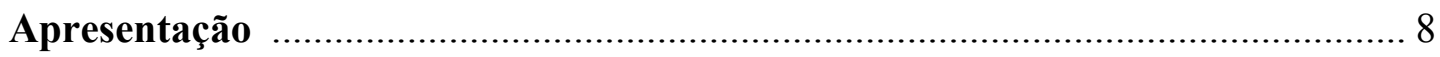

Capítulo 1 A violência contra as mulheres e a rede de serviços …..................... 12

Capítulo 2 Os psicólogos e a assistência a mulheres em situação de violência .. 29

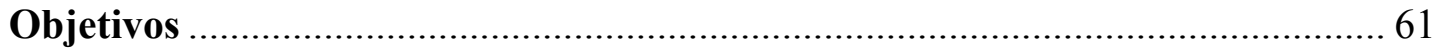

Capítulo 3 Referenciais teórico-metodológicos ................................................ 62

Capítulo 40 desenho e o campo da pesquisa ................................................... 92

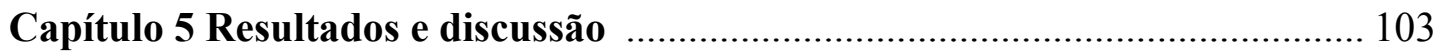

Parte I O psicólogo e a rede de assistência: normas e protocolos .......................... 103

Parte II A inserção dos psicólogos na rede de serviços paulista - resultados da

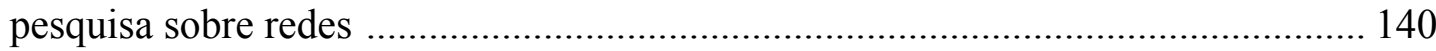

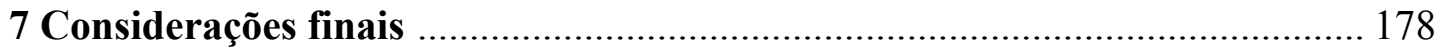

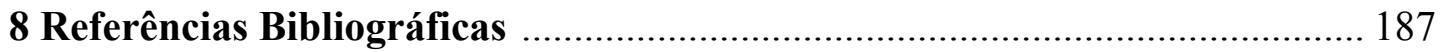

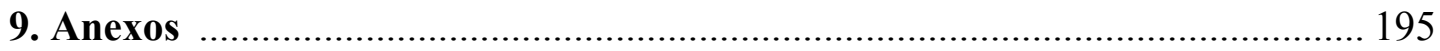

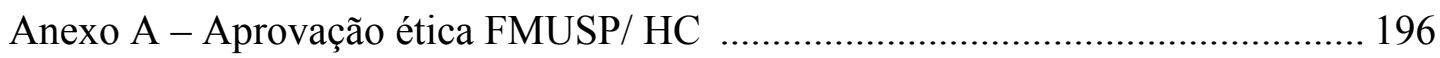

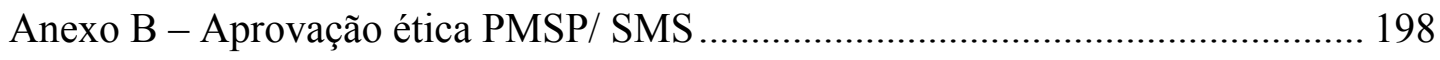

Anexo C - Consentimento informado ………................................................... 200

Anexo D - Consentimento informado (para serviços da PMSP/ SMS) ................... 202

Anexo E - Questionário de entrevista ............................................................... 204 


\section{APRESEnTAÇão}

Este estudo é um desdobramento da pesquisa "Identificando Possibilidades e Limites do Trabalho em Rede para a Redução da Violência contra a Mulher: estudo entre três capitais brasileiras", financiada pelo Ministério da Justiça e realizada em 2005, em parceria com SOS Corpo Gênero e Cidadania, em Recife e Themis Assessoria jurídica e estudos de gênero, em Porto Alegre.

Essa pesquisa - que a partir daqui chamaremos de "pesquisa sobre redes" teve como objetivo reconhecer a trama de serviços voltados para a assistência a mulheres em situação de violência e identificar os elementos que dificultam e facilitam a articulação do funcionamento em rede.

No presente estudo nos propusemos a identificar e analisar o lugar de um dos profissionais das equipes desses serviços, o psicólogo. A partir da perspectiva da necessidade e importância de ações multiprofissionais e intersetoriais no trato com o tema da violência de gênero, interessa-nos saber como o psicólogo se insere (ou é inserido) nas equipes, ou seja: como a assistência psicológica é pensada e organizada, e como suas ações são articuladas com outros profissionais e outros serviços.

A violência contra as mulheres é um problema cultural, social, de saúde pública e de direitos humanos relativamente recente, constituindo-se como objeto de intervenção novo para os serviços dos diversos setores da sociedade e para seus profissionais.

Partimos da concepção de que o trabalho efetivo com situações de violência de gênero não é específico de um profissional ou de um tipo de serviço, sendo 
necessária a composição de diversas áreas do saber, a atuação de profissionais de formações diferentes, envolvendo serviços de vários setores sociais. A assistência às pessoas em situação de violência, nesta perspectiva, tem caráter multidisciplinar, multiprofissional e intersetorial e pressupõe trabalho articulado em equipe e na formação de redes.

O trabalho efetivamente articulado em equipe multiprofissional e em rede intersetorial é um dos desafios atuais para os profissionais e instituições. Neste trabalho estão implicadas diferentes dificuldades, como a precariedade da rede de serviços, os limites institucionais, a existência de compreensões diferentes sobre o objeto e sobre os objetivos do trabalho, a diversidade de instrumentos de intervenção, de formas de organização do trabalho, e as ambigüidades das mulheres nas suas demandas para os serviços e profissionais.

Entendemos que, para compreender melhor os limites e possibilidades do funcionamento da rede de assistência, é importante compreender as relações e interações entre os serviços e programas, concretizados pelas equipes de profissionais de cada um deles. A rede efetiva-se pela ação de pessoas, que ocupam lugares, realizam atribuições e funções profissionais de acordo com sua inserção em cada serviço e na equipe multiprofissional, além de envolver profissionais dos níveis gerenciais e centrais das instituições e órgãos públicos. Os profissionais da assistência deveriam fazer a articulação da rede de serviços por meio de ações assistenciais complementares e articuladas, na relação com os profissionais dos outros serviços - por meio, principalmente, do encaminhamento e recepção de clientela e diálogo acerca dos casos atendidos. Consideramos, assim, que o trabalho de articulação da rede intersetorial de serviços deve ser articulação de ações 
assistenciais entre profissionais de formações diversas, inseridos em instituições ou setores sociais também diferentes, em termos de objetivos, forma de funcionamento, percepção do objeto de trabalho e intervenções realizadas. Além disso, o trabalho articulado pressupõe interação entre os agentes dessa rede, com comunicação dialógica com base em um projeto assistencial comum (Peduzzi, 1998).

Os profissionais têm atuações diversas, conforme as culturas institucionais dos serviços em que estão inseridos e as vocações assistenciais dos serviços, além das diferenças e especificidades de suas profissões. Para realizar uma atenção integral e efetiva às pessoas em situação de violência, nesta perspectiva, é necessário que os profissionais reconheçam o caráter parcelar e complementar do seu trabalho e a necessidade de articular suas ações com outros profissionais e outros serviços. é necessário, portanto, o reconhecimento mútuo entre os profissionais e entre os serviços, o que implica não só em conhecimento da existência dos outros serviços, mas também do trabalho realizado por eles.

Entendemos que é importante e necessário ter definições claras dos trabalhos específicos e daqueles que são comuns aos profissionais, para a articulação das ações de intervenção de maneira afinada e efetiva, tanto na equipe multiprofissional quanto na rede de serviços.

No atual estudo, demos foco ao trabalho do psicólogo e utilizamos os dados dos serviços que atuam com a violência contra as mulheres da região metropolitana de São Paulo, colhidos na pesquisa sobre redes. A partir das entrevistas com os profissionais destes serviços, fizemos um levantamento daqueles serviços que contam com psicólogos na sua equipe, descrevendo e analisando a distribuição, inserção e atividades realizadas por estes profissionais pelas diversas categorias de 
serviços. Desta forma, utilizamos informações do Relatório de Pesquisa (D’Oliveira e Schraiber, 2006) para apresentar a caracterização geral dos serviços estudados (em termos de objetivos, atividades e vínculo institucional), além de fazer análise de parte dos resultados - até então não analisados - obtidos pelas entrevistas realizadas na pesquisa sobre redes, para analisar a inserção especifica dos psicólogos nos serviços da região metropolitana de São Paulo.

Para discussão do trabalho do psicólogo também foram analisados os documentos normativos de orientação para a prática assistencial voltados para situações de violência contra as mulheres, do Ministério da Saúde e da Secretaria Especial de Políticas para as Mulheres. A partir destes documentos, verificamos qual o trabalho previsto para estes profissionais, na concepção dos formuladores de políticas.

Nos dois primeiros capítulos introduzimos o tema, definindo e justificando os objetivos deste estudo. No capitulo 1, situamos as principais questões: violência contra as mulheres e a constituição da rede de serviços voltada à assistência para este problema. No capítulo 2, apresentamos e comentamos a inserção do psicólogo nos serviços voltados para a assistência a mulheres em situação de violência, a partir da literatura nacional encontrada. Os referenciais teórico-metodológicos estão apresentados no capítulo 3. O desenho da pesquisa e a descrição do campo constam do capítulo 4. Finalmente, no capitulo 5, apresentamos e discutimos os resultados deste estudo. 


\section{CAPITUlo 1 - A ViolênCIA CONTRA AS MULHERES E A REDE DE SERVIÇOS}

Nos últimos 30 anos a violência doméstica contra a mulher, antes considerada um problema da esfera privada, vem sendo objeto de estudo e intervenção, a princípio, nas áreas da Segurança Pública e da Justiça e posteriormente na área da Saúde Pública, ganhando reconhecimento como um problema social, de saúde e de direitos humanos. (Gregori, 1993; D’Oliveira, 2000; Araújo, 2004, Schraiber et al, 2005a).

Diversos estudos populacionais realizados em diferentes países, desde meados dos anos 80 , demonstram a alta magnitude da violência contra a mulher. A ocorrência de violência física por parceiro íntimo, pelo menos uma vez na vida, atinge taxas entre $10 \%$ e $50 \%$ das mulheres das populações pesquisadas (Heise et al, 1999). No Brasil, 29\% das mulheres em São Paulo e 37\% na Zona da Mata de Pernambuco relatam ter sofrido violência física e/ou sexual pelo parceiro ou exparceiro, ao menos uma vez na vida. Já a violência física por outros agressores apresenta índices de 21\% em São Paulo e 13\% em Pernambuco; e a violência sexual por outros agressores, 7\% em São Paulo e 5\% em Pernambuco. No entanto, estes outros agressores não são desconhecidos das mulheres. A grande maioria deles são os próprios familiares, tanto na violência física quanto na violência sexual, o que caracteriza a violência contra as mulheres como doméstica e/ou familiar. (Schraiber e D’Oliveira, 2002b).

O reconhecimento internacional destas violências enquanto violação de direitos deve muito ao movimento de mulheres no mundo todo, que, desde a década 
de 70, tomou a iniciativa de denunciar a desigualdade nas relações entre homens e mulheres. A violência contra a mulher foi, desde o início, denunciada como uma das expressões desta desigualdade. Um dos resultados desta mobilização foi a inclusão do debate sobre a violência de gênero no âmbito jurídico internacional, em diversas Conferências de Direitos Humanos. Isso levou à formalização da proteção jurídica dos direitos das mulheres, enfatizando que são direitos humanos, bem como à formulação de diretrizes políticas baseadas na igualdade entre os sexos nos campos da saúde, trabalho, violência e poder.

Uma das conquistas mais relevantes ocorreu em 1994, em Belém do Pará, quando diversos países assinaram o compromisso de garantir os direitos das mulheres e de desenvolver ações de enfrentamento à violência contra as mulheres, na Convenção Interamericana para Prevenir, Punir e Erradicar a Violência contra a Mulher. Nesta Convenção, ratificada pelo Brasil em 1995, definiu-se a violência contra a mulher como

(...) qualquer ato ou conduta baseada no gênero, que cause morte, dano ou sofrimento físico, sexual ou psicológico à mulher, tanto na esfera pública como na esfera privada $\left(\right.$ Artigo $\left.1^{\circ}\right)$.

Neste mesmo ano ampliam-se os mecanismos de pressão política, com a Declaração e a Plataforma de Ação da IV Conferência Mundial sobre a Mulher (Beijing). Nestes documentos identificam-se os obstáculos existentes para a conquista da igualdade e o desenvolvimento das mulheres, e são definidas estratégias e ações de enfrentamento à violência de gênero. Há recomendações de ações no âmbito das leis, punição e reabilitação dos agressores, proteção, assistência e indenização das mulheres, criação de mecanismos institucionais para denúncias e registro de ocorrências. 
As reivindicações das mulheres foram gradualmente ganhando mais espaço e reconhecimento, e o movimento de mulheres foi conquistando assentos nas instâncias internacionais de defesa dos direitos e pressionando a formulação de diretrizes técnicas e políticas internacionais. $\mathrm{Na}$ área da saúde e de desenvolvimento social, o reconhecimento de órgãos internacionais, como BID, OPAS e OMS veio na esteira do interesse no desenvolvimento econômico e social das populações, já que a violência contra as mulheres tem impacto na força de trabalho, com aumento dos índices de absenteísmo e adoecimentos. Esta mobilização política fomentou não só a criação de serviços, como o desenvolvimento de pesquisas acadêmicas sobre o tema dos direitos das mulheres, incluindo a violência de gênero.

No Brasil, desde a década de 80 , muitos serviços específicos para o problema foram criados, cujas experiências contribuíram bastante para a aproximação e compreensão do problema, com reformulações conceituais e de propostas de enfrentamento à violência.

Os primeiros serviços foram os SOS Mulher, iniciativa do movimento feminista e que tiveram duração de alguns poucos anos, em São Paulo, Rio de Janeiro e Belo Horizonte. (Verardo, 1998a; Gregori, 1993). Nas décadas de 80 e 90, com a mudança de atuação do movimento de mulheres para maior responsabilização do Estado e cobrança de políticas públicas voltadas para o problema, foram criados outros serviços voltados para o tema, como as Delegacias Especiais de Atendimento à Mulher $\left(\mathrm{DEAM}^{1}\right)$, casas abrigo, serviços - governamentais e não governamentais de orientação e assistência jurídica, assistência médica e psicossocial.

\footnotetext{
${ }^{1}$ As Delegacias Especiais de Atendimento à Mulher (DEAM) é a denominação mais utilizada para este tipo de serviço. A sigla DDM (Delegacia de Defesa da Mulher) é utilizada somente no estado de São Paulo. Apesar de denominações diferentes utilizadas pelos autores consultados, neste estudo
} 
Em 2003, foi criada no Brasil a Secretaria Especial de Políticas para as Mulheres, com status de ministério, tendo como proposta a elaboração e execução de políticas para a igualdade de gênero, com destaque para o Programa de Prevenção, Assistência e Combate à Violência contra a Mulher. Esta iniciativa coroa os esforços, desde os anos 80, para a formulação e formalização de diretrizes políticas para as mulheres, no diálogo - permeado de idas e vindas - entre as instâncias governamentais e o movimento de mulheres.

No âmbito jurídico e legislativo, algumas alterações na lei brasileira possibilitaram, a partir de 1995, maior visibilidade dos casos de crimes contra as mulheres - no espaço público e doméstico - principalmente para os próprios operadores do Direito. Uma nova mudança legal foi a recente instituição, em agosto de 2006, da Lei 11340, popularmente denominada como Lei Maria da Penha, que nomeia e dispõe sobre os crimes de violência doméstica contra as mulheres e com a qual se pretende alterar o contexto de recorrentes arquivamentos de denúncias e processos, penas inadequadas (como a prestação de serviço comunitário ou doação de cestas básicas pelo agressor) e falta de proteção para as mulheres (que muitas vezes estavam sob risco de novas agressões ao voltar para casa e o convívio com o agressor após a denúncia), além de garantir a assistência à mulher, às crianças e aos agressores.

A lei Maria da Penha, a progressiva criação de serviços e a formulação de políticas públicas voltadas para o enfrentamento da desigualdade de gênero, representam passos no que diz respeito ao reconhecimento governamental brasileiro 
da violência e desigualdade de gênero e na efetivação dos compromissos assinados pelo país em conferências e convenções internacionais.

Apesar das conquistas no que diz respeito ao reconhecimento e legitimação do problema da violência contra a mulher, ainda é freqüente a banalização e a invisibilidade deste tipo de violência nos diversos âmbitos sociais e institucionais. Mesmo com a ampliação dos serviços voltados para o tema, estudos e avaliações de serviços demonstram que houve e ainda há muitas dificuldades na implantação das políticas e de funcionamento, supervisão e avaliação de serviços que efetivamente garantam a assistência e os direitos das mulheres.

Diversos estudos demonstram as dificuldades dos profissionais da Saúde (Ellsberg, 1998; Schraiber, 2001; Kiss, 2004; Souza e Adesse, 2005), das DEAMs (Barsted, 1994; Brandão, 1997; Machado, 2002; Silva, 2002), e de profissionais de outros tipos de serviços (Cabrejos, 1998) em identificar e prestar assistência às situações de abuso e/ou violência contra mulheres no Brasil e na América Latina. Em todas essas categorias de serviços os diferentes profissionais se deparam com a falta de capacitação no tema, limites para o trabalho, precariedade material e com as dificuldades e ambigüidades das mulheres em contar sobre e lidar com a violência sofrida. Podemos dizer que alguns dos obstáculos para uma melhor identificação e assistência a essas mulheres estão relacionados à dinâmica complexa e ambígua das relações conjugais violentas e à banalização das agressões, além do não reconhecimento da desigualdade de gênero por usuárias e profissionais dos serviços, o que redunda em não reconhecimento das agressões enquanto violência e enquanto violação de direitos. 
Apesar dos primeiros serviços voltados para o problema terem sido os SOS Mulher, as DEAMs e alguns serviços de assistência jurídica, inaugurando a assistência pela ênfase no direito das mulheres, a criminalização da violência na legislação só ocorreu em 2006, com a Lei Maria da Penha.

No entanto o setor policial parece estar mais adiantado no debate e na instauração de práticas no enfrentamento à violência do que o setor judiciário. $\mathrm{O}$ judiciário parece ser mais refratário ao problema da violência contra a mulher, pelo menos no que diz respeito a criação de serviços específicos, de procedimentos que garantam acesso à justiça para estas mulheres e na inclusão do debate da desigualdade de gênero na execução das leis. Vários autores (Barsted, 1994; Machado, 2002; Silva, 2002, Campos, 2003) apontam para a dificuldade do judiciário em incorporar as discussões sobre gênero, vista na manutenção de concepções tradicionais no julgamento dos processos e na legislação discriminatória em vigor até a recente aprovação da lei Maria da Penha. Concepções estas que estariam por trás dos freqüentes arquivamentos de processos e julgamentos com base na preocupação dos magistrados com a preservação da família e do casamento, além da adequação do agressor ao "estereótipo de bom provedor do lar". (Campos, 2003).

Para Campos (2003), o direito aplicado às mulheres, no Brasil, não estava regido pelos princípios do direito, mas pelo senso comum. Apropriado pelo juiz, o senso comum torna-se senso comum teórico (Warat, 1995, apud Campos, 2003²) e, portanto, ideológico, já que oculta "as formas na qual a realidade social exercita e distribui o poder". Ao insistir na neutralidade da lei, não questionar a violência praticada, nem a função que exerce na relação conjugal, nem o papel do Judiciário

\footnotetext{
${ }^{2}$ Warat, LA. Introdução geral ao direito: epistemologia jurídica da modernidade. Sergio Fabris, Porto Alegres, 1995, vol.II.
} 
nestes conflitos, os magistrados e todo o sistema judiciário acabariam por reforçar a postura masculina violenta, reafirmando a assimetria de gênero e descaracterizando a instituição Justiça perante as mulheres. Ao fazer isto, reprivatizar-se-ia o conflito, pois levar-se-iam para o âmbito público as próprias convicções particulares e pessoais sobre os comportamentos mais adequados na esfera privada. Observa-se que a banalização da violência contra as mulheres se expressa no aparato jurídico-policial pelos arquivamentos de processos, aplicação de penas mínimas, absolvição do agressor, além das tentativas de conciliações jurídicas.

$\mathrm{Na}$ saúde, o principal problema é a identificação da violência, pois o fenômeno se coloca para os profissionais indiretamente, pelos agravos à saúde, como hematomas, fraturas, dores diversas e recorrentes, sofrimento psíquico em geral, uso e abuso de drogas e álcool, DST de repetição, gravidez indesejada, aborto de repetição, negligência de cuidados com os filhos, entrada tardia no pré-natal (Heise et al, 1999; D’Oliveira, 2000; Schraiber, 2001). A tendência é de não reconhecer as agressões como violência e dar ênfase às conseqüências para o corpo, para as quais há recursos biomédicos de intervenção (cuidados para hematomas, queimaduras, fraturas, além daqueles direcionados à prevenção de DSTs/ HIV e gravidez indesejada). A banalização e a falta de capacitação evidenciam-se na invisibilidade do problema (Dantas-Berger e Giffin, 2005).

Segundo Schraiber (2001), o fato de não haver proposta de intervenção estruturada reforça a não identificação da violência pelos profissionais da saúde e a crença de que a intervenção deve ser de outros setores, como a polícia ou a justiça. Quando reconhecem alguma intervenção para os serviços de saúde, identificam como própria do serviço social ou da saúde mental. Para fazer o diagnóstico, lembra a 
autora, é preciso que o problema tenha sentido assistencial para o profissional, identificando e direcionando ações assistenciais quando vislumbram formas de intervenção dentro de suas competências técnicas.

É freqüente a crítica ao desconhecimento ou pouco conhecimento sobre o ciclo da violência e necessidade de treinamento e capacitação para o atendimento à clientela, por profissionais das DEAMs (Machado, 2002; Silva, 2002; Barsted, 1994), pelos operadores do direito em geral (Campos, 2003) e também para profissionais de saúde (Schraiber, 2001; Souza e Adesse, 2005).

Além disso, alguns autores avaliam que a assistência às mulheres fica prejudicada pela falta de padronização e sistematização dos procedimentos e condutas adotados nos serviços específicos para o problema. Nas DEAMs (Barsted, 1994; Machado, 2002; Gregori, 2006), o tipo de serviço mais estudado, isto se reflete em variações do atendimento prestados, em um padrão muitas vezes doméstico e informal, com recurso ao bom senso e a critérios pessoais para avaliar as agressões denunciadas e consequentemente, a necessidade de registrar as queixas. Nos centros de referência a falta de padronização é ainda mais ampla, pois há extrema diversificação do perfil dos serviços. No Encontro Nacional de Centros de Referência realizado em 2005 (SPM, 2006c), avaliou-se que, para melhorias dos serviços e maior efetividade da assistência, havia necessidade de padronização dos serviços, de criação de diretrizes comuns, de rotina de atendimento, de fluxograma, de um cadastro único, além de definições sobre a vinculação institucional. A iniciativa de tentar reverter esse quadro, a SPM elaborou as normas técnicas de uniformização para os centros de referência, publicada em 2006. 
Com relação às casas abrigo para mulheres em situação de violência o principal problema avaliado pela SPM (2003) é a necessidade de melhor articulação com a rede local de serviços voltados para o problema. Segundo a SPM, os abrigos têm baixa efetividade e sustentabilidade quando desarticulados de outros equipamentos.

Como vimos, há avanços, no sentido de um maior número e diversidade de serviços, mas ainda muitas dificuldades quanto a sua implantação, organização da assistência, protocolos e capacitação dos profissionais da assistência, com variações e particularidades conforme o tipo de serviço e setor assistencial envolvido. Por outro lado, apenas recentemente a questão do trabalho em rede vem sendo tematizada.

\section{A rota crítica das mulheres em situação de violência}

A pesquisa coordenada realizada pela OPAS (Sagot, 2000; Cabrejos, 1998) avalia a atuação dos serviços, a partir do uso de serviços pelas mulheres, identificando os fatores que dificultam e os que favorecem a busca por ajuda por essas mulheres.

O estudo "La ruta crítica de las mujeres afectadas por la violência intrafamiliar en América Latina" (Sagot, 2000), realizado em 1996 pela OPAS em 10 países da América Latina, investigou como as mulheres que vivem situações de violência intrafamiliar - especialmente a violência conjugal - buscavam ajuda e soluções para seus problemas, principalmente entre familiares, amigos, serviços jurídico-policiais e de saúde. Além destes serviços, também foram pesquisados serviços de medicina legal, educativo, organizações não governamentais de mulheres e comunitários (organizações de base e instituições da igreja). Para tanto, utilizaram 
diversos instrumentos: entrevistas semi-estruturadas com profissionais dos serviços, analise de documentos destes serviços, entrevistas em profundidade com mulheres que sofreram violência intra-familiar e grupos focais com pessoas das comunidades (homens e mulheres, jovens e adultos). $\mathrm{O}$ estudo mostra que as instituições e o Estado estão falhando na oferta de serviços, na qualificação dos profissionais, no fornecimento de informações à comunidade, na elaboração de protocolo assistencial, na proposição de leis que garantam os direitos e na criação de propostas para transformação de valores que poderiam propiciar o fortalecimento das mulheres para encontrar saídas para a situação de violência e garantir os direitos humanos, a saúde e o desenvolvimento das pessoas envolvidas na situação.

Neste estudo, levantaram-se os fatores que impulsionam e os que inibem as mulheres na procura por ajuda (quadros 1 e 2).

O principal obstáculo interno das mulheres para solicitar ajuda é a concepção cultural rígida sobre o papel da mulher como esposa e mãe, valorizando a preservação do casamento e a dependência da autoridade masculina, que levaria a relacionar a violência e a separação conjugal aos sentimentos de culpa, vergonha e desprestígio social. E entre os fatores externos que mais dificultam a procura por ajuda estão os custos, a burocratização e a cobertura limitada dos serviços, que dificultam o acesso à assistência; além das respostas inadequadas e não efetivas dos profissionais, que levam as mulheres a desistirem dos apoios institucionais. Por outro lado, os fatores mais significativos que precipitam o pedido de ajuda pelas mulheres são: quando a violência se intensifica em gravidade e/ou freqüência das agressões, ou quando estas agressões atingem os filhos. O apoio de outras pessoas, quando há, em 
geral é feminino (familiares, amigas ou profissionais mulheres). (Cabrejos, 1998, p.

100 e 119).

Quadro 1. Fatores que impulsionam a procura por ajuda

Fatores internos

Convencimento de que o agressor não A violência contra ela

vai mudar

Convencimento de que os recursos A violência contra filhos e filhas

pessoais se esgotaram

\begin{tabular}{ll}
\hline Raiva e desamor & Apoio de pessoas próximas \\
\hline Saturação com a situação & $\begin{array}{l}\text { Condições materiais e econômicas } \\
\text { favoráveis }\end{array}$ \\
\hline Colocar-se metas e projetos próprios & Informação precisa e serviços de qualidade \\
\hline & (Sagot, 2000, p.96 - tradução livre da autora)
\end{tabular}

Quadro 2. Fatores inibidores da procura por ajuda

\begin{tabular}{ll}
\hline Fatores internos & Fatores externos \\
\hline Medos & Pressões familiares e sociais \\
\hline Culpa & $\begin{array}{l}\text { Insegurança financeira e falta de condições } \\
\text { materiais }\end{array}$ \\
\hline Vergonha & $\begin{array}{l}\text { Atitudes negativas dos profissionais e } \\
\text { respostas institucionais inadequadas }\end{array}$ \\
\hline Amor pelo agressor & $\begin{array}{l}\text { Limitada cobertura das organizações } \\
\text { governamentais e não governamentais }\end{array}$ \\
\hline $\begin{array}{l}\text { Manipulação do agressor e dinâmicas } \\
\text { do ciclo da violência }\end{array}$ & $\begin{array}{l}\text { Contextos sociais com histórias de } \\
\text { violência }\end{array}$ \\
\hline $\begin{array}{l}\text { Idéia de que o que ocorre no interior da } \\
\text { família é privado }\end{array}$ & \\
\hline $\begin{array}{l}\text { Desconhecimento dos seus direitos e } \\
\text { falta de informação }\end{array}$ & \\
\hline
\end{tabular}

(Sagot, 2000, p. 102 - tradução livre da autora)

O sentimento de impotência das mulheres, para Sagot (2000), teria raízes, então, na própria violência, na falta de apoio, na impunidade do agressor e na falta de resposta institucional. Conclui que

Sus silencios son aprendidos, no necesariamente como un resultado más de los procesos de socialización de género, sino que responden fundamentalmente a las lecciones prácticas extraídas acerca de la efectividad de sus esfuerzos: son adjudicables a la falta de respuestas sociales adecuadas y no a características particulares de las mujeres maltratadas. Por esta razón, después de algún intento infructuoso, 
muchas veces tardan años en volver a hablar para pedir ayuda. (Sagot, 2000, p.105).

Tudo isto faz com que o caminho institucional percorrido pelas mulheres seja tortuoso, longo, fragmentado, não linear, sofrido e nem sempre bem sucedido.

No Brasil, nota-se, a partir de uma pesquisa populacional realizada por Schraiber e D'Oliveira em 2000, que os serviços mais procurados pelas mulheres que sofreram violência física e/ou sexual cometidas por seus parceiros foram: delegacias, serviços de saúde e líder religioso. Dentre as mulheres que relataram episódios de violência física, menos da metade (44\%) das mulheres paulistas e menos de um quarto $(21,9 \%)$ das mulheres pernambucanas procuraram ajuda em pelo menos uma instituição. Entre estas mulheres que buscaram ajuda, metade (55\%) procuraram somente um serviço, sendo que as outras $45 \%$ restantes procuraram mais de uma instituição e algumas delas chegaram a procurar até nove serviços. Os principais motivos relatados para a busca por ajuda foram: a saturação com a situação de violência (37,5\% em Pernambuco e 61,4\% em São Paulo afirmaram "não agüentar mais") e a percepção do risco (34,1\% em PE e 16,7\% em SP declararam estar "muito machucada/ medo de que a matasse") (Schraiber et al, 2005a). Estes motivos relatados pelas mulheres demonstram uma procura por ajuda tardia e em casos graves. O que confirma a conclusão de Sagot de que a intensificação da violência é um fator para a busca por assistência institucional, resultando no fato de que apenas mulheres com situações mais graves acabam por procurar ajuda. Além disso, os dados sinalizam que é uma procura institucional não especializada e relativamente pequena.

Dessa pesquisa, vê-se que a principal ajuda vem dos familiares e amigos, e muitas das entrevistadas nunca contaram sobre a violência para ninguém $(21,5 \% \mathrm{em}$ 
SP e $23,9 \%$ em PE). As principais razões para as mulheres não buscarem ajuda institucional foram: a convicção de que "a violência é normal” (55,6\% em SP e $54,6 \%$ em PE), o medo (18,5\% em PE e $13,4 \%$ em SP) e a vergonha $(9,6 \%$ em PE e $11,3 \%$ em SP). Estes resultados corroboram aqueles obtidos por Sagot, reafirmando a banalização da violência e indicando, talvez, a existência de estigma contra essas mulheres que sofrem violência doméstica (Schraiber et al, 2005a).

Os resultados da pesquisa coordenada por Schraiber (2005a) demonstram que a realidade brasileira não é diferente dos outros países da América Latina, pois as mulheres têm motivos semelhantes para procurar ou não ajuda institucional. A diferença dos dados entre São Paulo e Pernambuco, com uma busca por serviços maior em São Paulo, provavelmente tem relação com o fato de São Paulo ter maior quantidade de instituições voltadas para o tema. Essa maior oferta de assistência,

(...) seguramente aumenta o uso das mulheres e potencializa a efetivação dos direitos (...). (...) a existência destes locais favorece a percepção da violência como injustiça e a legitimidade de voltar-se contra ela, oferecendo alternativas concretas de ação. (Schraiber et al, 2005a, p.140).

Os dados obtidos nesses estudos sugerem que a assistência adequada e com qualidade favorece rotas mais resolutivas e dignas, potencializando a garantia dos direitos das mulheres e a mudança cultural para superação da banalização da violência.

No Brasil os esforços, nos últimos anos, para a elaboração e concretização de políticas públicas, na constituição de serviços e formação continuada dos profissionais, ainda que de forma irregular, vem no bojo do reconhecimento desta necessidade de respostas institucionais para o problema da violência de gênero. Em São Paulo os serviços voltados para o tema vêm crescendo nos últimos anos, o que 
podemos constatar pela quantidade de serviços descritos nas diversas edições do Guia de Serviços para Mulheres em Situação de Violência que publicamos (CFSS e CSEBP/ FMUSP, 2002; MJ/FMUSP, 2005). Na edição de 1996 a cidade de São Paulo contava com 40 serviços classificados por vocação assistencial (psicossocial, policial, assistência e orientação jurídica, médica e psicossocial especializada); em 1999, somavam 47 serviços; em 2002, incluindo outros municípios da Grande São Paulo, indicava 91 instituições; e hoje, na edição de 2005, foram levantados 127 serviços.

\section{A rede de serviços}

O enfrentamento da violência contra as mulheres, por ser um fenômeno que está relacionado a múltiplos fatores, demanda intervenções em diversos níveis da realidade social, desde o cultural, institucional, familiar, até o individual. (Heise, 1998; Heise et al, 1999)

No campo da assistência, faz-se necessário a integração de ações entre profissionais de várias áreas, pressupondo atuação em equipe multiprofisssional e compondo conhecimentos de disciplinas diferentes. A violência demanda ações de saúde (para tratamento e prevenção dos agravos físicos, emocionais, de saúde sexual e reprodutiva, e dores em geral), orientação e assistência jurídica (para situações de separação, disputa de guarda dos filhos, orientações sobre os direitos sobre bens, e para as situações que se configuram como crime), assistência policial (para denúncia de crimes, registro de queixas, proteção em situações de risco, retirada do agressor da casa), abrigo (nas situações de risco de morte para a mulher e/ou filhos), assistência social (para orientações sobre benefícios que auxiliem para a melhoria na condição 
de vida e/ou que contribuam para o enfrentamento da violência), psicossocial (para a elaboração da situação familiar violenta e construção de novos projetos de vida e padrões de relação afetiva).

Com demandas tão diferenciadas, observa-se que a violência contra a mulher é um problema sobre o qual os serviços não podem intervir e resolver isoladamente, necessitando da articulação com outros serviços, de vocação assistencial diferente, articulando as ações em rede. É um problema que demanda, como foi dito, ações interdisciplinares, multiprofissionais e intersetoriais, conforme reconhecido pela OPAS:

Las redes de acción contra la violencia intrafamiliar se han convertido en una estrategia y uma línea de trabajo que nace de la concepción de que la violencia intrafamiliar es un problema social que involucra al conjunto de los sectores, tanto públicos como privados, así como de la sociedad civil, de los organismos de iglesia, de las universidades y, en definitiva, de toda la comunidad para permitir una respuesta global, integral y multidimensional al problema y ya vimos como esa forma de organización social llamada "redes o coaliciones de acción" permite la flexibilidad necesaria para el involucramiento de diversos actores sociales en un sistema que puede responder más acertadamente a la complejidad de la violencia intrafamiliar, es decir una forma de abordar el problema no aislada, lo que permite la ejecución de tareas que se resuelven de manera complementaria y cooperativa. (OPAS, 1999, p.15)

Esta compreensão do fenômeno já está disseminada entre os especialistas que trabalham com o tema, sejam formuladores de políticas, pesquisadores, profissionais da assistência, participantes ou não do movimento de mulheres. Muitos profissionais dos serviços que prestam assistência às mulheres que vivem estas violências - no Brasil e em outros países -, ainda que não compartilhem completamente desta concepção, atuam com equipes multidisciplinares e articulam suas ações com outros serviços. Desta forma, um hospital que atende violência sexual, por exemplo, em geral conta com equipe médica, de enfermagem, psicólogos e assistentes sociais e 
acaba encadeando o seu trabalho com a assistência policial (DEAM e IML), e/ou de assistência e orientação jurídicas. No entanto, o trabalho interdisciplinar, em equipe multiprofissional, e ainda mais em rede intersetorial, não é tarefa fácil de concretizar e apresenta-se como um dos desafios para as instituições e os profissionais.

Um dos desafios para profissionais e usuárias é compor, numa assistência integral, as linguagens diferentes, específicas a cada setor assistencial e a cada profissão. Se para as equipes de cada tipo de serviço o problema a ser enfrentado é parcial, com foco no que é específico do setor no qual está inserido, para as mulheres o problema é único. E, dependendo das suas necessidades, essas mulheres são obrigadas a percorrer diversos serviços, com diversos desencontros.

Como visto, pelo estudo da OPAS (Sagot, 2000) e pelo estudo de Schraiber (Schraiber et al, 2005a), as instituições (especializadas ou não) ainda não oferecem assistência adequada e efetiva para as mulheres, resultando em rotas sofridas, longas e muitas vezes, ineficazes. Os profissionais em geral se deparam com inúmeras dificuldades na identificação, no acolhimento, assistência e encaminhamento das situações de violência, o que sinaliza, no mínimo, a necessidade de treinamento e supervisão sustentados e de boa qualidade.

A nosso ver, a assistência adequada e efetiva está relacionada ao reconhecimento das iniqüidades de gênero na nossa sociedade, pressupondo para os profissionais a reflexão sobre seus valores e suas concepções a respeito dos padrões de masculinidade e feminilidade culturalmente valorizados. Não ter clareza desses valores significaria realizar condutas assistenciais sob o risco de reproduzir e reforçar a desigualdade de gênero, apoiados em julgamentos morais a respeito dos comportamentos masculinos e femininos. Uma assistência de boa qualidade também 
exige repensar a própria postura profissional, as propostas assistenciais, o objeto, a finalidade e limites das ações, além de aprender a trabalhar de forma integrada com outros profissionais, de outras formações e de outros setores sociais. Ou seja, o problema da violência contra a mulher exige perceber que o objeto de intervenção tem múltiplas dimensões e que a intervenção não se esgota em um campo assistencial. Além disso, também nos parece necessário ter um conhecimento mínimo sobre os direitos, os objetivos e o funcionamento de serviços dos outros setores sociais, para que as orientações e encaminhamentos contribuam para rotas institucionais mais efetivas. Resumindo, trata-se de repensar e reinventar a prática profissional no cuidado com as vítimas e com os agressores. No entanto, este movimento não se dirige somente aos profissionais da assistência, mas também exige políticas institucionais mais integradas e alinhadas, que favoreçam este aprimoramento. 


\section{Capitulo 2}

\section{OS PSICÓLOGOS E A ASSISTÊNCIA A MULHERES EM SITUAÇ̃̃o DE VIOLÊNCIA}

\section{Sobre a Psicologia}

A psicologia é uma área do conhecimento e uma profissão recente - datam do final do século XIX e começo do século XX - e nasce no contexto da concepção moderna e liberal de indivíduo ${ }^{3}$. No Brasil, as primeiras atividades e estudos estavam vinculados à Filosofia, Educação, Medicina - especificamente a psiquiatria - e Trabalho e datam do inicio do século XX (Antunes, 2004) ${ }^{4}$. Pode-se dizer que foram contribuições aplicadas à compreensão e classificação do funcionamento mental dos alienados, do desenvolvimento e funcionamento cognitivo das crianças e seu processo de aprendizagem, além de realização de seleção de pessoas para o trabalho, configurando-se como profissão de ajustamento. A psicologia foi regulamentada como profissão em 1962, com a lei 4.119, que estabelece:

Constitui função privativa a utilização de métodos e técnicas psicológicas, com os objetivos: a) diagnóstico psicológico; b) orientação e seleção profissional; c) orientação psicopedagógica; d) solução de problemas de ajustamento. (p.115-116)

Muitos autores falam da diversidade (Kahhale, 2002) e alguns, mais críticos, do ecletismo (Figueiredo, 1991; Carone, 2003; Schmidt, 1999) das abordagens teóricas e de suas aplicações práticas como característica deste campo. Estes e outros

\footnotetext{
${ }^{3}$ Sobre a constituição do espaço psicológico e os modos de subjetivação contemporânea, ver "A invenção do psicológico: quatro séculos de subjetivação 1500-1900”, de Luis Cláudio Figueiredo, Ed. Escuta, São Paulo, 2002.

4 Foram utilizados artigos de Lourenço Filho (1969), Plínio Olinto (1944), Annita de Castilho e Marcondes Cabral (1950) e Samuel Pfromm Netto (1981), organizados por Mitsuko Aparecida Makino Antunes (2004), no livro "História da Psicologia no Brasil - Primeiros Ensaios".
} 
autores consideram que há uma diversidade de objetos e concepções de mundo que convivem no campo da Psicologia. No interior de cada campo de atuação - cujas fronteiras não são rigidamente demarcadas - convivem diferentes abordagens teóricas, que muitas vezes são opostas e implicam em práticas também diversas e/ou divergentes.

Coimbra (1995), comentando especialmente as práticas clínicas na psicologia brasileira das décadas de 70 a 90, retrata uma institucionalização marcada pelo corporativismo, sectarismo, brigas internas e pelo "mercado", busca de poder e hegemonia interna à categoria profissional - cuja área sempre foi dividida, principalmente com os médicos.

As outras áreas de aplicação da psicologia tiveram percursos um tanto diferentes, muitas vezes dialogando com a clínica, mas também com outras disciplinas científicas, constituindo-se como áreas de atuação diversas.

Assim, atualmente, em todas as áreas de atuação da psicologia, nota-se desde as concepções mais tecnicistas, que percebem o homem como ser a-histórico e detêm-se sobre os aspectos universais do humano, até as mais críticas, aquelas que consideram o homem como ser histórico e a subjetividade como sendo constituída nas relações concretas no contexto social, político e institucional.

Com relação à violência, Coimbra (2002) aponta para uma característica das práticas psicológicas no Brasil, que tende a tomar o problema - como outros fenômenos sobre os quais intervêm - pelo caráter privado, da esfera íntima, familiar, e portanto, despolitizando, despublicizando e psicologizando o problema. Desta forma, os espaços individualizantes seriam fortalecidos, com a intervenção girando em torno de características individuais, psicológico-existenciais e familiares dos 
sujeitos envolvidos nas situações de violência (tanto a doméstica quanto outras, especialmente aquelas perpetradas pelo Estado), naturalizando e essencializando estes conflitos. Considera que estas características de intimização, familiarismo e psicologização seriam marcas da atuação do psicólogo brasileiro e que dizem respeito "à própria produção desse espaço como território privado e à construção das práticas psi no país”. (Coimbra, 2002, p.83). Nesse sentido, afirma que não é por acaso que os psicólogos tendem a trabalhar com a violência doméstica e/ou intrafamiliar e não com violências institucionais.

É importante acentuar que a violência doméstica contra as mulheres não deveria ser tomada como fenômeno restrito ao mundo privado e familiar, pois têm dimensões políticas e sociais, vistas as iniqüidades de gênero na gênese do problema e as violações de direitos envolvidas. Nesse sentido, as discussões apresentadas neste estudo estão apoiados em Coimbra $(1995,2002)$, ao fazer a crítica a uma determinada maneira dos psicólogos brasileiros de conceber violência doméstica, aquela que considera o fenômeno somente pelos seus aspectos intra-psíquicos, existenciais e de dinâmica familiar. Ao fazer isto, os psicólogos naturalizam e essencializam os conflitos, desconsiderando os aspectos culturais, sociais e políticos, não se diferenciando muito de outros profissionais no que se refere à banalização destas violências.

\section{Os psicólogos e a violência contra a mulher}

Observando o Guia de Serviços para Mulheres em Situação de Violência, desde sua primeira edição, em 1996, nota-se psicólogos inseridos em serviços específicos de diversos setores assistenciais da região metropolitana de São Paulo. 
Assim, a atuação destes profissionais não está restrita à área da Saúde, compondo equipes na assistência jurídica, nas DEAMs, em ONGs diversas. Mesmo na Saúde, os psicólogos estão presentes em UBS e em serviços voltados para situações de violência sexual e/ou aborto legal, provavelmente desenvolvendo trabalhos um tanto diferenciados.

Foi realizada uma revisão de bibliografia nacional sobre avaliações de serviços voltados para o atendimento a situações de violência contra mulheres e sobre a prática dos psicólogos para este público, nas bases de dados Dedalus, BVS e Scielo, no período de 1999 a 2005, com as palavras chave "psicologia, violência, mulheres, serviços" e termos similares. Nestes artigos procurou-se ver intervenções propostas ou desenvolvidas pelos psicólogos na assistência a mulheres em situação de violência. A revisão restringiu-se às publicações que trazem descrição sobre o atendimento realizado e excluímos as que se referem aos serviços voltados para crianças, totalizando 12 artigos encontrados.

A partir desta literatura, pode-se observar uma primeira característica da inserção destes profissionais: ele é pensado tanto na composição da equipe de assistência à clientela dos serviços como no apoio aos outros profissionais que atuam na assistência às mulheres.

\section{Sobre o apoio aos profissionais}

Em uma pesquisa do CNDM sobre a avaliação das DEAMs, Silva (2002) identifica como principal demanda das delegadas a necessidade de pessoal de apoio para os atendimentos psicológico e social $(92,13 \%$ delas consideram como muito 
importante ter pessoal qualificado nestas áreas). Uma das necessidades relatadas pelas policiais é de apoio psicológico para os profissionais:

Necessitamos de apoio psicológico às funcionárias que compõem o quadro da delegacia, as quais acabam por envolverem-se emocionalmente nos problemas das vítimas. (p.14)

Este apoio psicológico provavelmente diz respeito a um potencial sofrimento decorrente do trabalho com estas situações. Segundo Brandão (1999), a necessidade do psicólogo para o trabalho policial nas DEAMs estaria relacionada a três dimensões da assistência. Uma delas seria a dificuldade das policiais em acolher as ambigüidades e sofrimento trazidos pelas mulheres e famílias nas suas queixas (já que muitas identificam necessidade de capacitação para a escuta destas demandas). As outras dimensões dizem respeito a dificuldades e conflitos na assistência: o reconhecimento, pelas policiais, da fragilidade emocional das mulheres e dos homens; e a distinção entre o que seria policial e o que não seria da sua competência, mas da esfera doméstica, familiar.

No caso dos abrigos, a inserção dos psicólogos seria um pouco diferente. A partir de uma pesquisa de avaliação do serviço oferecido por um centro de referência e um abrigo de Belo Horizonte, Alves e Coura Filho (2001), também identificaram, nos depoimentos dos profissionais, a necessidade de apoio, ainda que estes tenham considerado que a própria prática institucional contribuiu para o crescimento profissional. De maneira semelhante às policiais, identificaram este apoio com o trabalho do psicólogo, porém, na forma de psicoterapia para a equipe técnica. $\mathrm{O}$ artigo não revela a que se refere esta demanda por psicoterapia, ou melhor, que representações os profissionais têm sobre o trabalho psicoterápico, mas pode-se supor que os profissionais dos abrigos identificaram dificuldades pessoais no trato 
com a violência. Porém, diferente das policiais, que solicitaram apoio psicológico, os profissionais do abrigo também demandaram capacitação teórica sobre a complexidade do objeto. Identificaram, portanto, o apoio com a psicoterapia e a formação profissional no tema, o que evidencia as dificuldades destes profissionais no trato com a violência e a clientela, no âmbito técnico e pessoal. É uma percepção mais ampliada do que a das policiais, o que não é de se estranhar, pois estas últimas têm provavelmente menos proximidade com o trabalho dos psicólogos, por ser um serviço de vocação assistencial do tipo psicossocial.

Da mesma forma que os profissionais das DEAM e dos abrigos que identificaram o envolvimento emocional e as dificuldades encontradas na assistência com a necessidade de apoio psicológico/ psicoterapia, nota-se psicólogos desenvolvendo práticas que procuram responder a essas dificuldades.

Willians et al (2000) ofereceram "oficinas de psicologia" a policiais de uma delegacia da mulher. Esta equipe de psicólogos iniciou um programa de atendimento psicológico às usuárias de uma DEAM e, a partir do contato com as policiais, constataram freqüentes queixas de despreparo, com o comentário de que na Academia de Policia não estudavam psicologia. Propuseram então uma oficina de capacitação em "aspectos psicológicos da violência" que teve o objetivo de oferecer apoio e reflexão aos policiais da DEAM e, com isto, melhorar o atendimento às usuárias. As atividades desta oficina tiveram foco na reflexão em grupo de crenças a respeito da violência doméstica, por meio de discussão de temas, discussão de casos e de dramatizações de atendimentos inspirados nos casos atendidos pelo setor de psicologia na mesma DEAM. 
O que Willian et al (2000) denominam como "oficinas de psicologia" e "aspectos psicológicos da violência" na realidade referem-se a oficinas de capacitação realizadas por psicólogos, pois não tratam dos aspectos psicológicos envolvidos na violência, nem parecem compartilhar instrumentos ou recursos da psicologia que poderiam ser utilizados na assistência. $\mathrm{O}$ apoio oferecido, portanto, configura-se como uma oficina sobre gênero e violência, proporcionando reflexões sobre os próprios valores e crenças, e não exatamente como um "apoio psicológico" aos profissionais, no sentido de acolher demandas emocionais.

A demanda por apoio aos profissionais também está posta em outros setores assistenciais, mas não é necessariamente relacionada ao trabalho do psicólogo. O envolvimento emocional dos profissionais e dificuldades daí decorrentes apontado pelas policiais e talvez pela equipe técnica do abrigo também foi identificado em profissionais de saúde. Claudia Pedrosa (2003), em sua pesquisa de mestrado com profissionais de saúde de um hospital, apontou, a partir dos relatos destes profissionais, que o impacto emocional implicado no acolhimento das situações de violência, justamente pela falta de qualificação, pode resultar em violência institucional ou esforços para a reorientação da assistência.

Ficou evidente na pesquisa que entrar em contato com a violência produz forte mobilização afetiva nos profissionais, gerando ansiedade, angústia e medo. Nos diferentes exemplos citados, durante as entrevistas, nota-se que, além do despreparo, o acolhimento das situações de violência está intimamente associado à fragilização emocional. (Pedrosa, 2003, p.113)

Sem a capacitação para o enfrentamento da questão e sem ter a quem recorrer nos momentos de dificuldades, os profissionais vão aprendendo a lidar com a complexidade por meio da prática, criando a sua própria maneira de atendimento. Alguns se solidarizam e oferecem acolhimento; outros se distanciam, tratam com aspereza e às vezes acabam, sem perceber, maltratando e/ou agredindo as mulheres. (idem, p.114). 
A literatura evidencia duas formas de "enfrentamento" do impacto emocional e as dificuldades dos profissionais para lidar com a clientela e o tema da violência: intervenção psicológica direta aos profissionais, seja como apoio mais pontual e geral, seja como tratamento clínico, denominado como psicoterapia; e supervisão e capacitação no tema de violência de gênero, não necessariamente coordenado por psicólogos.

\section{Os psicólogos na assistência às mulheres}

No geral, os artigos encontrados trazem relatos de propostas de intervenção de psicólogos essencialmente clínicas (individual ou em grupo). As diferenças mais marcantes são aquelas que dizem respeito à duração e foco da intervenção (entre uma atuação mais pontual e outra com acompanhamento mais longo), e à articulação das ações assistenciais com a equipe multiprofissional.

Em cada setor assistencial há características e contextos institucionais diferenciados e, por isso, para melhor compreensão e discussão sobre a inserção do psicólogo devemos considerá-los no contexto de cada setor.

Segundo Barsted (1994), o projeto inicial das DEAMs já previa equipe multiprofissional, compondo o trabalho policial com a atuação de psicólogos e assistentes sociais. Pelos Guias de Serviços para a região metropolitana de São Paulo publicados em 2002 e em 2006, vemos que nas casas-abrigo e nos centros de referência o caráter da assistência pode ser considerado como psicossocial, tendo como equipe básica psicólogos e assistentes sociais. Na Saúde, os psicólogos estão previstos tanto na Atenção Básica como nos serviços ambulatoriais voltados para situações de violência sexual. E nos serviços de assistência jurídica também não é 
incomum encontrar psicólogos compondo a equipe, prioritariamente de advogados (D’Oliveira e Schraiber, 2006).

\section{Os psicólogos nas DEAMs}

Para Brandão (1997), as delegacias recortam, na queixa das mulheres, o que é passível de intervenção jurídico-policial, delimitando o que seria crime, recorrendo muitas vezes a encaminhamentos a assistente social, psicólogo ou igreja para o que identificam como sendo do âmbito social, psicológico ou espiritual. No seu relato etnográfico, apresenta falas das policiais sobre o perfil das mulheres que procuram a delegacia:

... uma escrivã refere-se à 'mulheres com uma auto-estima muito baixa, que precisam de terapia.' Outro policial traça seu próprio diagnóstico do problema: 'Casa mal, depois vem aqui reclamar. Precisa de psicóloga aqui para aconselhar estas mulheres'. (Brandão, 1997, p.27)

Silva (2002), analisando a pesquisa realizada pelo CNDM, comenta a distinção entre o trabalho policial e o "extra-policial", identificado pelas profissionais como próprio das DEAMs e da problemática da violência intrafamiliar. Assim como Barsted (1994), aponta a falta de definição e sistematização das atribuições e procedimentos das delegacias. As atividades de aconselhamento, orientação, mediação e conciliação de conflitos são vistos por uma parte das unidades como atribuições da DEAM, sendo que outra parcela considera que a DEAM deveria se restringir ao trabalho estritamente policial, cabendo aos outros serviços as atividades “extra-policiais". E aquelas que pensam que estas atribuições fazem parte do trabalho das delegacias no trato com situações de violência intrafamiliar, relacionam-nas ao trato humanizado ou ao caráter educativo e preventivo no combate à violência, 
ambos preconizados na proposta das DEAMs. Efetivamente, em 93,6\% das delegacias pesquisadas as policiais afirmam realizar atividades de aconselhamento. Porém, a maioria destas delegacias não conta com psicólogos ou assistentes sociais no seu quadro de pessoal (nem supervisão por estes profissionais), o que, segundo avaliação de Silva, compromete o desempenho nas funções de mediação, conciliação e aconselhamento. Silva levantou que em $91,2 \%$ das delegacias, as policiais afirmaram ser importante o trabalho desses profissionais no apoio à clientela e às próprias policiais.

O trabalho das DEAMs está intimamente ligado a questões de cunho social e psicológico. Por isso é de suma importância que o estado criasse mecanismos que possibilitassem as atividades de assistentes sociais e psicólogas junto às delegacias (não necessariamente dentro das delegacias, mas que as vítimas pudessem ser encaminhadas a estas profissionais).

Postulo que sejam lotadas nesta DEAM Assistentes Sociais e Psicólogas.

Se as DEAMs não forem estruturadas adequadamente com assistente social, psicólogos e orientadores, e etc., deve-se criar um órgão para esse fim.

(Silva, 2002, p.14).

Pelos dados da pesquisa e pela avaliação de Silva, pode-se pensar que as atividades "extra-policiais", de aconselhamento e mediação de conflitos, são, na compreensão das policiais, relacionados ao trabalho do psicólogo ou da assistente social. E que estes profissionais poderiam compor a equipe das delegacias ou estarem locados em outros serviços, porém, recebendo encaminhamentos das policiais.

Assim como as outras atividades extra-policiais, as atribuições dos psicólogos nas delegacias estariam associadas às atividades de prevenção da violência, ou como atividades complementares ao trabalho estritamente policial, com vistas a um melhor atendimento, acompanhamento e encaminhamento da vítima. (Machado, 2002). 
Porém, como aponta Brandão (1997), com limites difusos entre o que seria de competência da assistente social, psicólogo, AA, NA ou igreja. Parece, com isto, que a assistência psicológica, social, religiosa e moral estão confundidas no trabalho "extra-policial", demonstrando desconhecimento das especificidades de cada um. Ainda segundo esta autora, esta confusão ocorreria pelo caráter doméstico e familiar das principais queixas de violência contra as mulheres.

Porém, essa percepção não é unânime e nem consensual entre as policiais, constituindo um debate tenso no campo das instituições policiais. De qualquer maneira, observa-se que há, no setor policial, uma forte demanda para assistência na esfera psicológica, muito provavelmente pelo caráter percebido como privado e doméstico dos conflitos e crimes com que lidam.

Os psicólogos inseridos nas delegacias da mulher, no relato de suas experiências, trazem elementos para tematizar estas questões. $\mathrm{Na}$ proposta de atendimento psicológico de Gonzaga et al (1999), em uma delegacia de Maringá, realizado por estagiárias de Psicologia Jurídica, a inserção foi pontual e complementar ao trabalho policial. No fluxo assistencial desta delegacia, o primeiro atendimento da mulher era realizado pelo Serviço de Psicologia, que avaliava a necessidade da mulher de aconselhamento psicológico, orientações sobre seus direitos e/ou encaminhamento para os seguintes serviços: programa de atendimento ao dependente químico, centro integrado de saúde mental, unidade de psicologia aplicada e serviço de assistência jurídica. Entenderam que

(...) cabe ao serviço de psicologia, para que a resolução e esclarecimento do problema apresentado sejam efetivados, diminuir o nível de ansiedade da suposta vitima e prepará-la psiquicamente para o enfrentamento legal do problema, se necessário for. (..) Segundo 
Soares e Silva (1992) $)^{5}$, faz-se necessário ajudar essa mulher a discriminar o que pertence à sua história individual e o que é próprio da sua condição feminina, orientá-la com informações objetivas sobre os seus direitos. Em outras palavras, fortalecê-la para que possa sair da situação de violência em que se encontra. (Gonzaga et al, 1999, pp.213-214)

O trabalho do psicólogo inserido em delegacia da mulher, neste caso, ganhou contornos mais nítidos e específicos. O encaminhamento para serviços de saúde mental e dependência química denota a compreensão de que caberia um seguimento e trabalho psicológico específico e breve. Além disto, a escuta e o acolhimento pontuais tinham os objetivos de: diminuição da ansiedade, "preparação psíquica" para o enfrentamento legal, discriminação entre os aspectos da história individual e o que diz respeito às relações de gênero. Desta forma, o atendimento psicológico estava configurado como complementar ao trabalho policial, tinha objetivos mais claros e específicos, a intervenção tinha caráter pontual, e estava incluída no fluxo assistencial da DEAM. Independente de fazer uma avaliação desta proposta de tecnologia assistencial, se é ou não a mais adequada, pode-se considerar que ela fornece novos elementos para refletir sobre a articulação dos diversos trabalhos e especialistas na atenção às mulheres em situação de violência e mostra um lugar possível para a intervenção psicológica, articulando o trabalho com o trabalho policial.

A inserção pontual e breve também foi uma característica da intervenção proposta por Rodriguez e Vizzotto (1999), na qual estagiárias da disciplina Psicologia Comunitária e da Saúde realizaram plantões psicológicos semanais em DEAM. Diferente da experiência de Gonzaga et al (1999), o atendimento psicológico não era o primeiro atendimento dos usuários. A delegada $\mathrm{e}$ as escrivãs

\footnotetext{
${ }^{5}$ Soares, C.T.; Silva, T.B.C. Atendimento interdisciplinar à mulher vitima de violência. In: Psicologia e Instituição de direito: a prática em questão. Conselho Regional de Psicologia, Rio de Janeiro, 1992.
} 
encaminhavam os casos que identificavam como pertinentes e a proposta foi de atender mulheres vítimas de violência doméstica, ampliando o atendimento para a família (filhos e agressores). Após o atendimento, com possibilidades de retornos, podia ser sugerido encaminhamento a instituições de saúde para seguimento em psicoterapia.

No artigo, os autores circunscrevem o trabalho do psicólogo como um trabalho de saúde mental, de caráter preventivo. Porém, não é a compreensão de prevenção do crime, como na proposta inicial das DEAMs, mas de prevenção primária e secundária em saúde mental, pensando em evitar e reduzir doenças mentais na população. Desta forma, basearam a intervenção no diagnóstico precoce de patologias e intervenção na dinâmica individual e familiar.

(..) na promoção da saúde mental, o psicólogo deve estar capacitado para uma atuação que vise o atendimento à comunidade, superando o atendimento individual e clínico, mas sem perder a compreensão clínica do fenômeno social e a dinâmica da comunidade na qual trabalha. (...) a intervenção em prevenção pode ser caracterizada pelo atendimento que busca a compreensão da dinâmica familiar, de seu contexto sócio-cultural e não só um sujeito isolado na família considerado 'doente'. (Rodriguez e Vizzoto, 1999, p.42)

O psicólogo, levando em conta o funcionamento individual, grupal e institucional, poderia reconhecer o tipo de funcionamento familiar "que permite a manifestação da violência". O intuito seria identificar aspectos saudáveis e comprometidos da família, buscando preservar os "fatores adaptativos" e trabalhar os "conflituosos". A intervenção psicológica se daria pela compreensão e explicitação da problemática individual e familiar, auxiliando o cliente a refletir sobre sua realidade e suas relações conflituosas. Entendem que todos os membros da família seriam vítimas e agressores, em função de um padrão de interação e comunicação, compartilhado por todos, e que permitiria a violência. Partem da compreensão de 
família como sistema, onde cada um exerceria um papel, articulados e interdependentes e que garantiriam o equilíbrio dinâmico das interações e estabilidade do vínculo familiar. Assim, o diagnóstico teria que levar em conta, na interação familiar, o que seria expressão de dependência criativa e necessária e o que seria manifestação de dependência regressiva no contexto de cada família. Neste sentido, identificam alguns tipos de padrões e distúrbios na família ${ }^{6}$, que auxiliaria no diagnóstico e na elaboração de estratégias de intervenção especificas a cada caso.

Apesar de discorrerem sobre a influência e determinações sociais e culturais nos conflitos familiares fica claro que o foco da intervenção é na interação familiar e que toda a discussão sobre violência de gênero não é levada em conta. E, do relato dos casos, percebe-se que todas as atitudes das pessoas atendidas foram interpretadas também no contexto da dinâmica familiar, inclusive as recusas com relação ao retorno no plantão e aos encaminhamentos sugeridos (todos para psicoterapia individual ou familiar).

Nessa segunda intervenção descrita, os psicólogos se inserem de forma menos articulada com o trabalho policial, recorrendo a um formato e instrumentos mais tradicionais da pratica psicológica. Apesar de configurarem o trabalho como pontual, na forma de plantão, vê-se que os objetivos e as justificativas remetem a intervenções de médio e longo prazo, com perspectiva de prevenção em saúde mental. Nesse sentido, é possível entender que o trabalho proposto poderia ser realizado em outros locais, como unidades básicas de saúde.

É importante lembrar que a segurança pública tem como objetivo combater o crime, ou seja, investigar e reprimir crimes, protegendo a população. Já os psicólogos

\footnotetext{
${ }^{6}$ Utilizam a sistematização feita por Richter, H. A Família como Paciente. Martins Fontes, São Paulo, 1996.
} 
são profissionais do cuidado, tradicionalmente associados aos setores da saúde. Esta diferença, que implica em objetivos, finalidades, instrumentos, culturas institucionais e saberes diferenciados entre policiais e psicólogos, possivelmente constitui um dos obstáculos para o diálogo entre estes profissionais e consequentemente, para a institucionalização das equipes multiprofissionais prevista no projeto inicial das DEAMs.

Cabe aqui algumas considerações sobre o atendimento prestados pelas DEAMs. A dinâmica complexa das relações conjugais violentas sempre representou uma dificuldade para a efetivação destes serviços, que se refletiu em ações não padronizadas das policiais, geralmente recorrendo a intervenções de cunho social, psicológico e/ ou moral. Em parte, isso seria conseqüência das freqüentes solicitações de interrupção dos procedimentos jurídicos pelas mulheres e à concepção das policiais de que a violência tem natureza social que transcende as atribuições e capacitações das policiais. (Gregori, 2006; Silva, 2002; Machado, 2002; Brandão, 1997). Barsted (1994) comenta que o atendimento das DEAMs variava bastante, indo do padrão "doméstico" e informal, às vezes até "maternal”, à postura burocrática e impessoal. Avalia que a proposta inicial do movimento feminista de equipe interdisciplinar não se efetivou, sendo que as delegacias que compunham suas ações com outros profissionais ou os tinham na equipe, o fizeram mais por iniciativa pessoal de algumas delegadas do que por determinação do nível central da gestão. Esta personalização na condução das DEAMs teve influência do estreito contato principalmente no início, segundo Barsted (1994) - com o movimento feminista, que tinha esta característica como uma de suas diretrizes. Era inclusive, junto com a atuação voluntária e militante, umas das marcas do trabalho assistencial dos SOS 
Mulher. Característica que, por um lado, trouxe às DEAMs o acolhimento humano e solidário inexistente nas delegacias comuns. A autora considera ainda que foi esta personalização que conferiu a algumas delegadas a sensibilidade para tentar reconciliações e resolver conflitos do casal. Porém esse caráter maternal, de acolher os desabafos, permitiu por outro lado o uso do "bom senso" para julgar as agressões ou conflitos relatados, inclusive para decidir se cabia registrar a queixa ou não. Esta ambigüidade entre a lei e o "trato pessoal" estaria presente também no debate das próprias feministas, quando falam da especificidade do atendimento das DEAMs. (Barsted, 1994). Este debate remete à humanização do atendimento policial, e não necessariamente implicaria em uma postura "maternal", o que aperfeiçoaria o trabalho de orientação e defesa dos direitos das mulheres. Com isso, privatizam-se os espaços percebidos como "femininos", o que significa descaracterizar a violência como problema de ordem pública a ser trabalhado no âmbito legal.

Parece ser nessa ambigüidade e divergências na forma de acolher as usuárias das DEAMs que o psicólogo se insere. As tarefas de aconselhamento, de mediação de conflitos, educação e prevenção, por muitas policiais consideradas como "extrapolicial", são previstas no projeto inicial destes serviços, para serem realizadas pela equipe multiprofissional como um todo. Porém, não foram delineadas e são atividades assistenciais para as quais as policiais parecem não possuir instrumentos. Tarefas que são identificadas - pelo observado acima -, pelas policiais e por alguns psicólogos - com o trabalho do psicólogo, o especialista que intervém nas relações interpessoais e conflitos afetivos/ emocionais. Porém, o trato humanizado é o que motivou a criação destas delegacias e o que as diferencia das delegacias comuns. Nesse sentido, é importante alertar para a possibilidade de que o atendimento 
psicológico à clientela das DEAM esteja a serviço do alívio da tensão e dos questionamentos sobre o caráter educativo e preventivo das delegacias da mulher, além do alivio da tensão das policiais quanto à falta de capacitação e às dificuldades de acolhimento às demandas das mulheres. Desta forma, um trabalho de equipe simplesmente justaposto e não dialogado poderia não representar melhorias na assistência prestada pelo serviço, porque as policiais não incorporariam o caráter educativo e preventivo do trabalho, nem o atendimento mais humanizado. Também porque as psicólogas poderiam não incorporar a dimensão do direito nas suas intervenções.

\section{Serviços de Assistência Jurídica}

Como já visto no capitulo 1 , o setor judiciário é o mais refratário ao tema violência contra as mulheres e não é por acaso que foi encontrada pequena bibliografia sobre a assistência prestada nos serviços. A atenção dos autores é maior nas discussões sobre a legislação e o aparelho jurídico como um todo.

Na pesquisa sobre redes (D’Oliveira e Schraiber, 2006) observou-se que muitos serviços de assistência jurídica nas cidades estudadas não reconhecem as situações de violência de gênero que estão por trás das demandas de processos judiciais e nem organizam ações especificas para o problema. Aqueles que reconhecem, em geral, são os serviços criados especificamente para atender estes casos.

Da literatura levantada, a experiência de mediação jurídica em uma ONG paulista foi o único relato de intervenção realizada por psicólogos em serviços jurídicos que encontramos. 
A mediação familiar, conforme Muszkat (1998), seria um método que compõe conhecimentos das ciências sociais, jurídicas e psicológicas, para a resolução de conflitos, no qual um mediador

(...) auxilia os membros de uma dada família na resolução dos seus conflitos através de uma compreensão aceitável por todos do problema em questão, em que se busca manter continuidade das relações entre as pessoas envolvidas. Trata-se de um método legal de negociação consensual para casos de separação e divórcio (...) (Muszkat, 1998, p.218).

Qualquer profissional de nível superior pode realizar esta função. Nos serviços pesquisados no estudo sobre redes (D’Oliveira e Schraiber, 2006), em geral são advogados, psicólogos ou assistentes sociais.

É uma técnica que não se restringe às situações de violência e também pode ser utilizada em outros contextos, como na capacitação de educadores de rua, professores e conselheiros tutelares. (Muszkat, 1998). Para as famílias em situação de violência, este atendimento, no serviço referido por Muszkat, tem como objetivos, entre outros:

(...) promover a transformação de padrões de relacionamento indesejáveis dentro das famílias por meio da proposição de novas formas de resolução de conflitos; intervir nas relações de poder baseadas nas discriminações de gênero. (Muszkat, 1988, p.218)

Há uma compreensão de que, nestas famílias, a violência é o meio predominante de resolução de conflitos, cujo padrão precisaria ser alterado. Consideram as influências sócio-culturais na formação da identidade masculina de controle e dominação sobre as mulheres, e da identidade feminina submissa, percebendo as agressões (físicas, psicológicas e sexuais) masculinas como forma de restituir a virilidade, poder e controle sobre as esposas e filhas. 
Na proposta de Muszkat (2003), o profissional teria a função de auxiliar na resolução de conflitos conjugais, facilitando o diálogo entre o casal e buscando a compreensão aceitável do problema para as duas partes. As diferenças estariam na compreensão que cada profissional pode ter - em função da sua formação - sobre a situação de conflito e ser trabalhada. O processo da mediação consiste em reunir informações, identificar e definir o problema, identificar os papéis de cada membro do grupo familiar, desenvolver opções, e redefinir práticas e posições. No serviço descrito pela autora, a mediação é um dos momentos da proposta assistencial realizada pelo conjunto dos profissionais, que compõe com atendimentos específicos - social, psicológico e jurídico -, desde a triagem até a finalização da assistência.

O trabalho de mediação deste serviço evidencia que o atendimento de casal pode ser focado na promoção do diálogo e entendimento dos parceiros, sem configurar-se como psicoterapia, já que não é um trabalho específico de psicólogos.

\section{O trabalho psicossocial - abrigos e centros de referencia}

As casas-abrigo e os centros de referência, ambos voltados para mulheres em situação de violência, podem ser classificados como serviços psicossociais, pois têm trabalho baseado principalmente no atendimento psicológico e social. No entanto, as casas-abrigo atuam sobre contexto específico, que é a situação de risco para a mulher, portanto, cabe distingui-los.

\section{Abrigos}

As casas-abrigo foram criadas para proteger as mulheres em situação de violência doméstica que estejam em condição de risco de vida iminente. Constituem- 
se como moradia segura e temporária, para as mulheres e seus filhos, oferecendo atendimento integral com o objetivo de contribuir para a reestruturação da suas vidas. Para isto, além do abrigo em endereço sigiloso, em geral oferecem orientação sobre os direitos, apoio psicológico, encaminhamentos para o mercado de trabalho, entre outros benefícios para a manutenção do cotidiano, como inserção das crianças em escolas locais ou encaminhamentos para atendimento médico, social e jurídico.

O trabalho em abrigo tem particularidades próprias da situação de abrigamento e da situação de risco que levou a este isolamento, que o diferencia dos outros serviços, quais sejam: a gravidade dos casos e o risco de vida presentes, a condição de vitimização e dependência afetiva e financeira, o isolamento familiar e social, que são características comuns a estes casos graves de violência conjugal. Além destes, as mulheres abrigadas também se deparam com a condição de institucionalização, a convivência de famílias que não se conheciam e não optaram por morar juntas, a moradia provisória e o sentimento de desamparo, o isolamento social e familiar proporcionado pelo abrigamento e a necessidade de segurança, além da necessidade de reformular a reconstruir as condições concretas de vida (trabalho, escola, moradia). Tudo isto faz com que a assistência tenha fluxo e organização próprios deste tipo de serviço e exige dos profissionais o manejo de questões e problemas que não se apresentam nos serviços em geral. Por exemplo, o manejo dos conflitos e até agressões entre as abrigadas, a intermediação da relação entre mães e filhos; o acompanhamento da busca por trabalho e moradia. Por um lado, têm os problemas e dificuldades de uma instituição fechada e por outro, a complexidade da dinâmica das relações violentas, muitas vezes reproduzidas no abrigo pelas usuárias. A promoção da autonomia e a reestruturação da vida cotidiana é um tema freqüente e 
importante no trabalho desenvolvido nestes serviços e compreendido como um elemento necessário para que a mulher não retorne à situação conjugal de violência (com o mesmo parceiro ou com outros).

Alves e Coura-Filho (2001), em avaliação do Centro de Apoio à Mulher de Belo Horizonte, que é composto por um centro de referência e uma casa-abrigo, evidencia esta preocupação. A avaliação foi feita utilizando entrevistas com usuárias, ex-usuárias e funcionários dos dois serviços, além de dados de prontuários e tinha como objetivo avaliar a percepção deles a respeito do atendimento destes serviços. Com relação à percepção das usuárias do abrigo sobre os atendimentos recebidos, as respostas mostraram que as usuárias estavam satisfeitas com os atendimentos, mas sentiam-se sem liberdade. As mulheres também temiam não conseguir resolver seus problemas sem o apoio da instituição e metade delas esperavam ter tido atendimento psicológico individual, além do atendimento de grupo. Resultados que, para os autores, denota dependência institucional, "indicando necessidade de escuta especializada, porém remetendo-nos à possibilidade de que a abrigada seja tutelada e não assistida" (p.249). Estes dados, concluem, evidenciam a tensão entre prevenir e socorrer, assistir e tutelar.

Com relação à inserção do psicólogo, este artigo não oferece detalhes suficientes para pode-se vislumbrar como é realizada a assistência pelo profissional e pela equipe. Como o serviço compõe casa-abrigo e centro de referência, não fica claro se as equipes são compartilhadas pelos dois serviços.

O artigo de Machado (2004) descreve uma das possibilidades de atendimento psicológico em abrigo. Como outros trabalhos citados, também foi uma experiência de estagiárias em psicologia jurídica, e constituiu-se em intervenção por 3 meses, 
com atendimentos semanais e temas surgidos espontaneamente. Inicialmente, realizaram atendimento individual para o "fortalecimento em suas individualidades" para depois participarem do grupo e buscarem soluções coletivas ou aproximadas para suas problemáticas. Para isto, tomaram como base experiências anteriores e a suposição de que a institucionalização e intervenções de caráter coletivo suprimem a individualidade. Identificaram sentimentos de desamparo e abandono das mulheres, com conseqüente desestruturação pessoal e organizaram a intervenção em grupo com foco no acolhimento e na construção de narrativas próprias de suas histórias.

O acolhimento caracteriza-se por escuta irrestrita (...), visando a uma qualificação constante dos sentimentos apresentados. A partir do reconhecimento e aceitação de si, esperou-se um fortalecimento das mulheres como pessoas, por meio da possibilidade da apresentação de narrativa atualizada em que a história possa aparecer ampliada em possibilidades. (Machado, 2004, p.98)

Entendem a terapia narrativa como uma abordagem que recusa identificar as pessoas/ pacientes como problemáticas ou rótulos, mas considerando que as pessoas estão lidando com problemas.

(...) sua ênfase está no conjunto de competências da pessoa para ampliar suas possibilidades existenciais, por meio da revisão de suas idéias sobre si mesma e seu trato com questões cotidianas. Um de seus pressupostos é o de que vivemos e nos construímos como pessoas por meio das historias, e que estas estão sempre abertas para serem reautoriadas, re-escritas ou atualizadas. A Terapia Narrativa trabalha de modo a separar as pessoas das narrativas saturadas de problemas, compreendendo a identidade como um projeto sempre em aberto, construído nas relações com redes que compreendem outras pessoas, a família e as instituições. (Machado, 2004, p.100)

No primeiro momento, propuseram os encontros para catarse e escuta compreensiva, com o intuito de entender a rede de significados das histórias. Permitiu-se que a dor se ampliasse, fosse contada e exposta, tendo as psicólogas que conviver com a angústia de ouvir e não propor, nem ter expectativas. Elas não 
aconselhavam, mas repetiam as falas, ampliando-as. Entendem que a dor, quando exposta e ampliada, torna-se conhecida e assim, passível de manejo. Também consideram que durante a exposição/ narração dos seus percursos dolorosos, as mulheres mostravam "seu instrumental de resiliência" e a rede de suporte que era composta pelos familiares, e em geral, era uma rede feminina.

Concluem que o acolhimento e incentivo à narrativa facilitaram o surgimento de novas autorias, de outros caminhos e possibilidade de escolha, "oposta à desorientação da narrativa imobilizante das "vítimas"”. (Machado, 2004, p.104)

Nesta intervenção nota-se também a preocupação em promover a autonomia e o deslocamento das mulheres da condição de vitima, para planejarem novas possibilidades concretas de vida.

No relato não há referências ao trabalho dos outros profissionais da equipe e nem ao trabalho já desenvolvido no abrigo, aparentando ter sido uma intervenção isolada e justaposta, sem articulação com os outros tipos de assistência. Apesar disto, o trabalho proposto parece estar bastante afinado com as principais preocupações das casas-abrigo em geral.

Porém, com relação à dinâmica e aos resultados, o trabalho parece ser semelhante à proposta de grupos de auto-ajuda, onde o caráter terapêutico está na troca de experiências. Desta forma, não se trata de uma intervenção específica de psicólogos. O que há de específico da psicologia nesta intervenção talvez seja a compreensão e análise do processo do grupo e das mulheres, e a clareza do manejo dos temas e do acolhimento das falas. 


\section{Centros de Referência}

Junto com as DEAMs e as casas-abrigo, os centros de referência compõem a política de enfrentamento à violência contra as mulheres e foram importantes na conquista da visibilidade social para o tema, bem como para o acolhimento e assistência destas mulheres. Desde o princípio, constituem-se como serviços especializados no atendimento a mulheres em situação de violência, sendo referência para os outros serviços. Costumam integrar atendimento psicológico, social e jurídico, prestando serviços de orientação, informação e assistência. Muitos deles mantêm estreito vínculo com o movimento de mulheres e soma-se às suas ações a mobilização no enfrentamento à violência e desigualdade de gênero.

Os centros de referência caracterizam-se, como vimos no capitulo 1, pela diversidade e não padronização da assistência. Pelos artigos levantados, vê-se que todos procuram acolher as mulheres no seu sofrimento e intervir nos padrões de relacionamento conjugal e/ou familiar.

Vagostello et al (2003), relatando seu trabalho de sala de espera como espaço terapêutico, entendem que a natureza da intervenção seria “clínico-social". Inicialmente, propuseram o trabalho para mulheres com histórico de violência, cujos filhos estavam em atendimento psicológico em um centro de referência paulista. A proposta foi “criar um espaço de discussão e orientação de questões relacionadas aos seus filhos", tornando-se rapidamente - em função da necessidade delas - em “espaço de relato das próprias histórias, dificuldades e sentimentos conflitantes com relação ao agressor". Concluem que a experiência aponta para

(...) outras modalidades de atendimento institucional, diferenciadas da terapia de grupo, que possibilitem a criação de um espaço de grupo no qual se permita o acolhimento necessário para o estabelecimento de relações de confiança e de comunicação recíproca e através do qual se 
produza algum efeito terapêutico em seus participantes. (Vagostello et al, 2003, p.31)

No Centro de Apoio Bemvinda, em Belo Horizonte (Alves e Coura-Filho, 2001) os psicólogos são inseridos em diversos momentos do fluxo assistencial, que consiste em: serviço de acolhimento; pré-atendimento (que consiste em 2 encontros semanais e no qual todas as mulheres passam, com exceção os casos urgentes); serviço de psicologia, que realiza atendimentos em grupos e individuais; serviço jurídico que procura orientar e encaminhar, com relação às questões jurídicas, para instituições competentes; após a passagem pelos diversos atendimentos, oferece-se as oficinas de pós atendimento.

A equipe de psicologia realiza atendimentos em grupos e individuais, as oficinas de pós-atendimento - que funcionariam como grupos terapêuticos para usuárias que já passaram pelos outros atendimentos - e também atuam na coordenação do "pré-atendimento", que tem como objetivo

(...) a formação de grupos de atendimentos visando à informação e principalmente à busca de conscientização no que tange não somente à situação 'problema' mas, proporcionam o encontro com o próprio eu e com isso ser possível um vislumbrar de horizontes diferentes daquele - a vítima, a pobrezinha, a coitadinha. (Alves e Coura-Filho, 2001, p.247).

Semelhante às propostas descritas para abrigos, nota-se a preocupação com a vitimização das mulheres em situação de violência, a necessidade de narrar as próprias histórias e de "fortalecer as individualidades".

Araújo (1996) relata a experiência de um serviço no atendimento em psicoterapia a famílias em situação de violência e fornece um relato mais aprofundado sobre a condição de vitimização e a necessidade de fortalecimento destas mulheres. 
No serviço no qual Araújo estava inserida, a assistência psicológica consistiu no atendimento das mulheres através de grupos de vivência e terapia individual, de grupo, de casal e de família. Tem o objetivo de

"apoio e fortalecimento da auto-estima, desenvolvimento de suas potencialidades para que possam superar suas dificuldades pessoais e ampliar sua participação na família e na sociedade". (Araújo, 1996, p.11)

A inclusão dos homens no atendimento surgiu da percepção de que havia, entre a clientela e os profissionais, uma compreensão polarizada entre vítima e algoz, limitando o olhar à realidade dos conflitos conjugais. Observaram, no relato das histórias das mulheres, a repetição da situação de violência, em condição de opressão masculina desde a infância, com tendência de suas filhas a reproduzir as histórias. Olhando para a dinâmica das relações de gênero e tentando compreender a violência de uma perspectiva mais ampla, iniciaram o trabalho incluindo os homens.

A proposta de terapia de casal visava trabalhar os conflitos conjugais, a violência, a comunicação, as diferenças de gênero, os desejos e expectativas e o processo de separação, se este aparecesse como possível solução. Utilizaram técnicas psicodramáticas e trabalharam o vínculo conjugal. Observaram que as mulheres manifestavam resistência à terapia conforme percebiam sua participação nos conflitos, evidenciada nas dramatizações. Perceberam que de alguma forma, permitiam ou se submetiam à situação, surpreendendo-se por se dar conta de que também tinham responsabilidade na construção da relação que tanto criticavam. A tendência a culpabilizar o homem por tudo foi questionada. Os homens, no início resistentes à terapia, reagiram bem ao processo, manifestando certa satisfação por também serem acolhidos, poderem falar de seus sentimentos, por serem ouvidos. A 
maioria dos casais optava pela separação, que se dava de forma menos conflituosa. Para os casais que resolviam manter o casamento, propunha-se retorno em 3 meses.

$\mathrm{O}$ atendimento de famílias era geralmente realizado com a mãe e os filhos. $\mathrm{O}$ pai, embora ausente, era tema freqüente durante o processo.

Os problemas mais freqüentes passavam pela dificuldade da mãe separada em lidar com os problemas dos filhos diante da separação. Quando a mãe não consegue lidar com sua própria ansiedade e insegurança diante da nova situação, ou quando está muito magoada e ressentida com o ex-companheiro, não consegue dar o suporte afetivo que os filhos precisam. O maior problema, nesses casos, é a dificuldade da mãe - e do pai - de separar as magoas e ressentimentos do ex-companheiro de maneira a não manipular os filhos ou acentuar seus conflitos, principalmente o conflito da lealdade. (Araújo, 1996, p.14)

Nos casos em que não era possível trabalhar com o casal, propunha-se o trabalho de grupo com mulheres. "O fio condutor era a compreensão das relações de gênero como uma construção social, como algo passível de mudança”. Afirmam que as mulheres passavam a perceber as relações de forma mais ampla, compreendendo a condição feminina, o machismo como comportamentos socialmente construídos que levam a situação de desigualdade, opressão e submissão.

Olhando o conjunto dos artigos, o trabalho do psicólogo parece estar identificado com o fortalecimento da auto-estima, o deslocamento da condição de vítima, a reflexão sobre os padrões de relacionamento e mudança destes padrões. A estratégia de atendimento em grupo parece ser uma escolha freqüente, tendo a troca de experiências um efeito terapêutico relevante. No entanto, lembramos que estes aspectos já eram privilegiados na proposta dos SOS Mulher, a primeira iniciativa do movimento de mulheres na assistência às situações de violência doméstica. Tinham objetivos diferentes, bem como a compreensão sobre a violência contra as mulheres e sobre a opressão masculina. Mas o fortalecimento e as atividades em grupo para 
troca de experiências eram as principais estratégias de conscientização e enfrentamento da violência.

Em São Paulo, esse serviço esteve ativo por 3 anos, entre 1980 a 1983, com reformulações, esvaziamentos e crises. A definição mais clara do atendimento do SOS Mulher em São Paulo foi formulada no decorrer da experiência do atendimento às mulheres vítimas e suas histórias, configurando-se basicamente como uma prática de conscientização e mobilização de mulheres pelos seus direitos. O trabalho de assistência, denominado "plantões de atendimento" era desenvolvido voluntariamente por mulheres militantes do movimento feminista e consistia em atividades de grupo onde as histórias de vida eram relatadas e feitas orientações sobre os direitos civis. A finalidade era estimular a solidariedade e cumplicidade entre as mulheres, romper o silêncio/ desvendamento das vivências particulares, descobrir coletivamente os "dispositivos" de poder e opressão aos quais as mulheres estavam submetidas, partilhar as experiências como forma de fortalecimento. Além de auxiliar as mulheres a sair da situação de violência, a intenção era também ampliar a visibilidade e ação do movimento feminista, tanto pela diversificação das ações, pela divulgação na mídia, e também pela expectativa de que as mulheres atendidas se integrassem ao movimento. Cabe ressaltar que o trabalho era intencionalmente não governamental e não profissional. Ou seja, apesar de ser realizado por mulheres de diversas formações, inclusive psicólogas, a assistência se configurava como apoio mútuo feminino e não como oferta de serviços de profissionais específicos. (Gregori, 1993).

Os pressupostos dos trabalhos de conscientização eram de que o isolamento reitera a subalternidade, ao impedir a percepção de que há uma condição comum a 
todas as mulheres; haveria uma interiorização da dominação masculina, cuja desconstrução era necessária. A atividade em grupo tinha como objetivo o estabelecimento de uma relação de confiança mútua, certa intimidade, perda do medo e da vergonha, vistos como necessários para que as mulheres se colocassem enquanto sujeitos - na relação com o serviço e consequentemente, na sua vida. (Gregori,1993).

Atualmente, a assistência às mulheres tem um caráter mais técnico e menos militante do que a proposta dos SOS Mulher. Mas pode-se observar permanências quanto às estratégias de intervenção e objetivos pretendidos, principalmente quanto à estratégia de grupo para troca de experiências, os objetivos de fortalecimento das mulheres, a promoção da reflexão sobre o problema como um fenômeno social e cultural.

\section{Saúde}

Na literatura levantada, não foram encontrados artigos de psicólogos sobre o trabalho realizado em serviços de saúde. Porém, na percepção dos outros profissionais de saúde, o trabalho do psicólogo é frequentemente citado como relevante na assistência às situações de violência.

Alguns estudos apontam que as intervenções sobre as situações de violência, na área da Saúde, são compreendidas pelos profissionais como pertinentes aos cuidados de saúde mental (psicólogos ou psiquiatras), havendo uma prática de encaminhamento destes casos para este setor ou estes profissionais. (Pedrosa, 2003, Kiss, 2004, Heise et al, 1999, Schraiber, 2002, D’Oliveira, 2000). Parece, assim, haver uma identificação, pelos profissionais de saúde, entre o tema e o trabalho do psicólogo. 
Kiss (2004), em seu estudo sobre a compreensão do problema por profissionais de saúde da região metropolitana de São Paulo, levanta que médicos, profissionais de enfermagem e gerentes, no geral, não reconhecem o problema da violência de gênero no cotidiano de suas atividades assistenciais. Esta invisibilidade se dá pela medicalização da violência, ou seja, desconsideram-se os aspectos sociais, ocorrendo uma redução para os sintomas e lesões, a imputação de um estado patológico aos sujeitos envolvidos na situação de violência e uma leitura biomédica que recorre ao uso de medicação psiquiátrica para amenizar o sofrimento. (Kiss, 2004, p.192). A parcela do problema da violência que caberia ao profissional da saúde, principalmente ao médico, portanto, seria cuidar dos impactos físicos e biológicos. Quando pensam na assistência a outros aspectos, remetem ao psicólogo, à assistente social e algumas vezes, à delegacia ou advogado. Ao psicólogo, na perspectiva desses profissionais entrevistados, caberia promover ou resgatar a autoestima da mulher, acolher e orientar ou tentar promover entendimento do casal. (Kiss, 2004, pp.108, 163).

No estudo "La Ruta Crítica de las Mujeres Afectadas pela Violencia Intrafamiliar en América Latina" publicado pela OPAS em 2000, há resultados semelhantes ao da pesquisa de Kiss (2004). A partir do relato das mulheres sobre a procura por ajuda, identificaram que os profissionais médicos e de enfermagem têm visão biologicista e medicalizadora, e remetem-nas para o serviço social, psicólogo ou psiquiatra. Quanto aos psicólogos, concluíram que:

... focam o trabalho nas manisfestações e sintomas, e não nas causas da violência", o que consideram uma intervenção "psicologizante", que "raras vezes ajudam as mulheres maltratadas em seus processos de empoderamento e busca de justiça e soluções aos seus problemas de violência. (Sagot, 2000, p.33). 
Muitos dos atendimentos psicológicos relatados nos artigos focam o trabalho em aspectos individuais e privados do conflito vivido pelas mulheres. Atuam no fortalecimento de individualidades, da auto-estima, na promoção do entendimento do casal, na diminuição da ansiedade, fazem diagnósticos de patologias familiares, ou assumem as tarefas de escuta e acolhimento que não deveriam ser restritas aos psicólogos. Parece, com isso, haver uma tendência dos profissionais e serviços, e dos próprios psicólogos, em individualizar e privatizar os conflitos interpessoais, algumas vezes psicologizando o problema. Talvez seja, neste movimento de "privatização" das violências contra a mulher, que os profissionais dos diversos serviços identificam a necessidade de intervenção do psicólogo.

Esse movimento de privatização e psicologização pode ter relação com a banalização da violência de gênero e a falta de capacitação com compreensão mais ampliada do objeto de intervenção para todos os profissionais, incluindo o psicólogo. Além disso, as dificuldades de infra-estrutura e de organização dos serviços (em termos administrativos e assistenciais) também podem representar outros obstáculos para a construção de um projeto assistencial onde os diferentes saberes e técnicas se complementem e dialoguem para uma atenção integral.

Como visto no início deste capítulo, a psicologia é um campo do conhecimento consolidado há pouco e suas práticas são marcadas muito mais pela diversidade e ecletismo do que pelo consenso, com abordagens teóricas que refletem visões de mundo e concepções de homem diversas e divergentes, além de fronteiras pouco claras com outras profissões. Diante desse quadro é de se supor que o diálogo e a integração do trabalho multiprofissional na assistência a mulheres em situação de 
violência terão outras limitações, que se somam à própria complexidade e dificuldades no lidar com o tema da violência de gênero. Um tema e um problema social também novo e para o qual não há intervenções consolidadas. 
Após estas considerações introdutórias, explicitamos os objetivos deste estudo.

\section{OBJetivos}

Este estudo buscou descrever e compreender a inserção dos psicólogos na rede de assistência voltada à violência contra as mulheres, procurando:

- Identificar, nos documentos normativos de orientações para a prática assistencial, as atribuições previstas para o psicólogo nos diversos serviços específicos voltados para o problema;

- Identificar os serviços específicos da região metropolitana de São Paulo, com ações assistenciais voltadas para situações de violência contra as mulheres, nos quais os psicólogos estão inseridos;

- Caracterizar as atividades desenvolvidas pelos psicólogos na rede de atendimento especifica da região metropolitana de São Paulo;

- Verificar se e como estas formas de trabalho se articulam na equipe e na rede de serviços específicos voltados para violência contra mulheres, na região metropolitana de São Paulo. 


\section{CAPITUlO 3 - RefERenCiais TeóRICO-MEtodológicos}

Para descrever e analisar a inserção dos psicólogos na rede de serviços voltada para mulheres em situação de violência, foram utilizadas contribuições de alguns autores acerca dos temas que articulamos neste estudo. Parte-se da concepção de gênero para compreender a violência contra as mulheres, apoiada no conceito proposto por Scott (1989). Para pensar o trabalho assistencial dos psicólogos nos diversos serviços, recorreu-se a uma parte das contribuições de Mendes-Gonçalves (1992) sobre processo de trabalho em saúde, a tipologia proposta por Peduzzi (1998) a respeito das equipes multiprofissionais em saúde, o conceito de técnica moral dependente de Schraiber (1997) e aspectos da discussão sobre redes sociais (Marteleto, 2001, 2003).

\section{Violência de Gênero - Distinguindo termos e conceitos}

O foco do estudo é a violência contra as mulheres, porém, é importante apresentar as diferentes noções de objeto que têm origem tanto de trabalhos acadêmicos como do movimento de mulheres, e que orientam as práticas assistenciais.

Os termos violência contra a mulher, violência de gênero, violência doméstica e violência intrafamiliar circunscrevem de formas diferentes fenômenos próximos e implicam em diferentes concepções da violência nas relações de intimidade ou da violência contra a mulher. (Gregori, 1993; Brandão, 1997; D’Oliveira, 2000; Araújo e Mattioli, 2004). Não são definições claramente 
demarcadas, nem correspondem a abordagens teóricas bem delimitadas. São denominações que surgiram das discussões políticas e acadêmicas que envolvem o tema, muitas vezes alimentadas e tendo como ponto de partida a experiência de intervenção com mulheres em situação de violência. Cada termo desses encerra uma concepção ligeiramente diversa do problema e consequentemente, informam propostas de intervenções distintas. É uma história que tem início, então, nas primeiras intervenções públicas contra a violência dirigida às mulheres, passando pelos diversos serviços criados conforme o tema ganha reconhecimento como um problema social.

Esta história se confunde com a história do movimento feminista, pois foi ele quem chamou a atenção para a desigualdade de poder entre homens e mulheres, para a opressão masculina sobre as mulheres e para as agressões sofridas - nos âmbitos público e privado - pela condição de ser mulher. Foi também pelas ações das feministas que o tema da violência doméstica saiu da esfera privada e ganhou relevância como um problema social e político, desde os anos 70 .

Pode-se dizer que, atualmente, os termos violência contra a mulher e violência de gênero remetem a agressões físicas, sexuais e psicológicas cometidas por qualquer agressor, acentuando a condição de mulher como fator importante para a ocorrência das ações violentas. Ou seja, dizem respeito a agressões dirigidas às mulheres e às meninas, de qualquer um dos três tipos, cometidas pelo companheiro, ex-companheiro ou outro familiar, estupro cometido por estranhos, abuso sexual de meninas, assédio sexual no trabalho, prostituição forçada, tráfico de mulheres, turismo sexual, violência institucional, mutilação genital feminina, agressões e assassinatos ligados ao dote, estupro em massa em situações de guerra. (Gregori, 
1993 e OEA, 1996 apud D’Oliveira, 2000). Estas expressões foram cunhadas em épocas diferentes, em diversos contextos históricos, políticos e de discussão teórica sobre o tema. O termo violência contra a mulher foi bastante utilizado na década de 70, principalmente pelo movimento de mulheres, que enfatizava a desigualdade de poder entre homens e mulheres, sendo a violência uma expressão dessa opressão feminina, historicamente construída. Já o termo violência de gênero remete a discussões mais recentes, a partir da década de 90, que trazem uma concepção relacional sobre a violência, com crítica à polarização e identificação cristalizada entre mulher/ vítima e homem/agressor, e ao discurso da vitimização da mulher.

Os termos violência doméstica e violência familiar/ intrafamiliar dizem respeito a agressões e abusos (físicos, sexuais ou psicológicos ${ }^{7}$ ) dirigidos a qualquer pessoa que compartilhe o ambiente doméstico ou familiar. Em geral, as pessoas mais vulneráveis são as mulheres, crianças e idosos, e os agressores, pessoas conhecidas e pertencentes ao círculo de relações de intimidade. As expressões não são sinônimas, uma vez que há diferenças quando se circunscreve o ambiente doméstico e o ambiente familiar, incluindo a família extendida: um circunscreve o fenômeno às relações de moradia e o outro, aos laços de parentesco. Violência doméstica foi e é um termo bastante utilizado pelas feministas e, em geral, refere-se à violência contra a mulher nas relações de intimidade, sendo que, por vezes, também diz respeito à violência doméstica ou familiar contra crianças. No entanto, violência intrafamiliar costuma abranger a violência contra mulheres, crianças, idosos, normalmente sem utilizar o referencial de gênero, ou seja, costuma-se acentuar o caráter dos laços de

\footnotetext{
${ }^{7}$ Alguns autores (Ministério da Saúde, 2001; OMS, 2002) também incluem a violência econômica, moral e negligência na tipologia da violência doméstica e da violência intrafamiliar. A tipologia violência física, sexual e psicológica são mais consensuais. Mais recentemente incorporam-se também as categorias violência financeira ou patrimonial e moral, que estão contempladas na lei 11.340 de 2006.
} 
parentesco e não considerar tão importante as desigualdades de gênero na origem e manutenção dos comportamentos agressivos ou das relações violentas.

Apesar destas grandes diferenças, as duas expressões tratam de agressões no âmbito das relações de intimidade, sejam elas familiares ou de moradia. Sabemos que os principais agressores de mulheres, crianças e idosos são homens, de relações próximas (pais, padrastos, tios, filhos...). O caráter privado, íntimo e de relações de confiança traz, muitas vezes, como conseqüência a invisibilidade, a impunidade e a cronicidade do fenômeno. (Schraiber et al, 2003; Ministério da Saúde, 2001).

Violência conjugal também é um termo bastante utilizado para nomear a violência entre marido e mulher, namorados ou ex-parceiros. Acentua o caráter relacional do fenômeno, incorporando as agressões perpetradas por mulheres contra os homens e entre casais homossexuais. É importante notar que, nesta perspectiva, é comum minimizar ou desconsiderar a desigualdade de gênero e os estudos que demonstram a alta prevalência e gravidade da violência de homens contra as mulheres. Há estudos que demonstram que as mulheres também agridem fisicamente seus companheiros. Reichenheim et al (2006), em estudo sobre violência conjugal ${ }^{8}$ em 15 capitais brasileiras, concluem que mais mulheres relataram ter agredido fisicamente seus companheiros (pelo menos uma vez) do que as que relatam terem sido agredidas e que em metade das situações as agressões são mútuas. No entanto, as agressões masculinas são mais severas e constantes. Quanto a isto, outros autores (Saunders, 1986; Marshall, 1999; Johnson, 2000; apud Reichenheim et al, 2006)

\footnotetext{
${ }^{8} \mathrm{O}$ artigo está escrito em inglês e o termo utilizado foi intimate partner violence, mas foca o estudo na violência psicológica e física entre casais.

${ }^{9}$ Saundersm DG. When battered women use violence: husband-abuse or self-defense? Violence Vic 1986; 1:47-60.; Marshall LL. Effects of men's subtle and overt psychological abuse on low-income women. Violence Vict 1999; 14:69-88.; Johnson MP, Ferraro KJ. Research on domestic violence in the 1990s: making distinctions. J Marriage Fam 2000; 62:948-63.
} 
apontam que parte destas agressões são revides às agressões masculinas (físicas ou psicológicas). E é consenso que a violência dos homens contra as mulheres tem maiores repercussões à saúde e integridade física, psicológica e de restrições de liberdades individuais do que a violência de mulheres contra homens. Circunscrevendo este tipo de violência, entre casais, o movimento de mulheres utiliza - principalmente entre as feministas americanas - o termo violência por parceiro íntimo. Em inglês o termo intimate partner violence, assim como a expressão violência conjugal, também não distingue o sexo do agressor, mas é normalmente utilizado para falar da violência masculina contra mulheres, no âmbito das relações de intimidade. Permanece, assim, o acento na relação desigual de gênero, mas delimitando o fenômeno das agressões nas relações amorosas, sejam os envolvidos casados, namorados, ex-parceiros ou parceiros sexuais ocasionais. Fenômeno que tem características próprias e difere da violência intrafamiliar, em freqüência, gravidade, recorrência e dificuldades de resolução ou saída da situação/ relação violenta.

Cabe explicitar a discussão sobre a violência de gênero, para melhor compreensão de suas implicações nas práticas nos serviços. Além de ser um termo atualmente bastante utilizado - algumas vezes banalizado, sem apropriação das discussões que será apresentado a seguir - é também a perspectiva pela qual será trabalhada neste estudo.

O conceito de gênero surgiu da necessidade de aprofundar a discussão e compreensão sobre a relação desigual entre os sexos e suas implicações sociais, históricas, culturais. No Brasil, essa discussão ganha força a partir dos anos 90. Para Barbieri (1993), 
(...) do ponto de vista histórico, a categoria patriarcado resultou em um conceito vazio de conteúdo, que nomeava algo sem, entretanto transcender essa operação - de forma tão vaga que o termo tornou-se sinônimo de dominação masculina, mas sem valor explicativo. Do ponto de vista político foi útil para a mobilização, mas não sobreviveu à polêmica com os críticos do feminismo e nem permitiu fazer frente aos conflitos imediatos encontrados na prática do movimento. (Barbieri, 1993, p.3).

Scott (1989) faz uma discussão sobre as diferentes compreensões e usos do termo gênero, desde que começou a ser utilizado, ressaltando que não é um conceito fechado, ou seja, ainda há discussões e construções a serem realizadas para que se constitua enquanto categoria de analise social consistente. E propõe uma definição, composta de duas partes:

O gênero é um elemento constitutivo de relações sociais baseado nas diferenças percebidas entre os sexos.

O gênero é uma forma primeira de significar as relações de poder.

(Scott, 1989, p.14)

A primeira afirmação implica em considerar os símbolos culturais que sintetizam e representam o masculino e o feminino. Estas representações não são únicas nem unívocas, e podem conter dentro delas elementos contraditórios. Contradição que pode-se, no caso do feminino, observar em alguns símbolos como Eva, Maria e mitos não cristãos "da luz e da escuridão, da purificação e da poluição, da inocência e da corrupção" (Scott, 1989, p.15). Uma segunda consideração é de que há conceitos normativos, expressos, por exemplo, em doutrinas religiosas, educativas, científicas, políticas ou jurídicas, que afirmam e direcionam a interpretação do sentido destes símbolos de maneira binária e categórica, desconsiderando outras possibilidades de sentido, “como se essas posições normativas fossem o produto de um consenso social e não de um conflito" (Scott, 1989, p.15). 
A autora faz uma terceira consideração, de que há a necessidade de incluir a política neste debate, lembrando que houve uma redução, por parte de alguns pesquisadores antropólogos, do uso da categoria gênero ao âmbito doméstico e familiar como fundamento da organização social. Desconsiderando, assim, - para as sociedades modernas - o mercado de trabalho, educação e o sistema político, esferas que também se constituíram historicamente com base na diferenciação entre os sexos. Basta lembrar a divisão sexual do trabalho, as instituições educativas restritas a homens, o sufrágio masculino universal. A quarta consideração é sobre a identidade subjetiva. Neste ponto, Scott concorda com Gayle Rubin sobre a contribuição da psicanálise - no caso, especificamente da perspectiva de Lacan para a compreensão sobre a construção de identidade de gênero dos sujeitos, que se configuraria como uma descrição da "transformação da sexualidade biológica dos indivíduos na medida da sua enculturação". Porém, questiona a pretensão universal da psicanálise e chama a atenção para o caráter histórico da construção da identidade de gênero, que segundo ela, estaria negado nesta perspectiva psicanalítica.

Com a segunda afirmação, Scott acentua que as distribuições de poder (de controle ou acesso desigual a determinados recursos materiais e simbólicos disponíveis na sociedade) estão implicadas na forma como se concebe as relações de gênero em determinada sociedade, construindo e sendo construídas por estas concepções. E, ainda, que as oposições entre masculino e feminino são utilizadas para legitimar as desigualdades nas relações e fenômenos sociais "O gênero é, portanto, um meio de decodificar o sentido e de compreender as relações complexas entre diversas formas de interação humana". (Scott, 1989, p.17) 
Esta legitimação das desigualdades a partir de diferenças biológicas é o que é chamado de naturalização da violência de gênero.

De forma geral, com o conceito de gênero, há a concepção de que as diferenças físicas e biológicas seriam um ponto de partida para a construção cultural, numa trama de valores, crenças, sentimentos que compõem modelos femininos e masculinos. No entanto, entendemos que mesmo a idéia de "ponto de partida" é questionável, já que implicaria em um corpo anterior à cultura, portanto uma realidade biológica "neutra”, o que na nossa concepção, não é possível. Corpos biológicos são compreendidos e ganham significado apenas na inserção da cultura e em determinado tempo histórico. Mesmo a ciência biológica, que define as diferenças sexuais tem seu tempo histórico de existência e está inserida em um contexto cultural. Como afirma Butler (1987), gênero é uma forma de viver o corpo no mundo, integrando, com esta afirmação, as dimensões concreta e simbólica da construção das diferenças de gênero.

Os modelos femininos e masculinos informam aos sujeitos concretos alguns valores e princípios, configurando-se como parâmetros e influenciando atitudes. Seriam "ideais" culturais, valorizados, reproduzidos e atualizados socialmente, mas não correspondem exatamente ao exercício e construção individual da identidade como mulher ou como homem de nenhum sujeito particular. Estes modelos seriam construídos de maneira relacional, ou seja, as identidades femininas e masculinas se definem na referência e por oposição ao outro, delimitando funções e lugares diferentes e específicos. Assim, reflexão sobre as mulheres remete à reflexão sobre os homens. Isto representa a superação da noção de esferas separadas para cada sexo, considerando gênero como elemento ordenador da prática social. Ao falar em 
masculinidades e feminilidades, de forma não sobreposta a homens e mulheres, abrese outras possibilidades de transformação das relações assimétricas. No entanto, alguns autores - especialmente Scott - fazem uma crítica: ao dar ênfase aos aspectos relacionais, à dimensão social, à desigualdade cultural, há o risco de perder a crítica política e da desigualdade de poder presentes em nossa sociedade.

Há então, nesta proposta de conceito, uma compreensão de que "há diferentes processos de subjetivação e singularização vivenciados por homens e mulheres", de diferentes formas de identificação e de expressão da masculinidade e feminilidade, seja mais próximo ou mais distante do modelo hegemônico (Araújo e Mattioli, 2004). Há ainda o reconhecimento da dominação masculina e do discurso hegemônico masculino, mas tanto mulheres quanto homens participariam da construção das relações e interações estabelecidas (D’Oliveira, 2000). Desta forma, considera-se a violência de mulheres contra homens, entre homens e entre mulheres, além da violência dos homens contra as mulheres. Todas estas violências seriam expressões de conflitos entre os modelos de masculinidade e feminilidade que cada um tem pra si e para outros, o que se consegue exercer destes ideais e o que se cobra ou se exige que o outro seja. (Araújo e Mattioli, 2004).

O próprio movimento feminista preferiu utilizar o termo mulheres em situação de violência, em substituição a mulheres vítimas de violência, como resultado das reflexões e experiências com o tema, buscando uma posição menos essencializadora e maniqueísta sobre o fenômeno. (Verardo, 1998b). O termo vítima foi importante para enfatizar a violência e contrapor à banalização das agressões masculinas contra as mulheres. No entanto, o debate sobre gênero e a prática de assistência a estas mulheres evidenciou um outro impasse: ao considerar a mulher 
como vítima, coloca-se a mulher como passiva e não autônoma na resolução dos conflitos. E as próprias mulheres, muitas vezes, não se reconhecem como vítimas, seja por reconhecerem sua parcela de responsabilidade nos conflitos familiares e conjugais, seja por também serem agressivas com o marido ou com os filhos, ou mesmo por rejeitarem este lugar cristalizado de subordinação.

As elaborações sobre o conceito de gênero permitiram o foco sobre homens e masculinidades nos trabalhos com saúde reprodutiva, ao incluir os homens na intervenção e promover a reflexão sobre a responsabilidade masculina na saúde e planejamento reprodutivo do casal. (Garcia, 1998; Acosta e Barker, 2003; Medrado e Lyra, 2003).

Com relação à violência de gênero, os homens são os principais perpetradores da violência contra homens e contra mulheres, sendo que eles sofrem principalmente violência física no espaço público, enquanto as mulheres, física e sexual no âmbito doméstico (Schraiber et al, 2005b). Considerando as diversas modalidades de masculinidades exercidas pelos homens, alguns autores (Hong, 2000, Connell, 2001, Cecchetto, 2004; apud Schraiber et al, 2005b) discutem a relação entre a aquisição dos atributos masculinos e os comportamentos violentos. As categorias "masculinidade hegemônica" e "hiper-masculinidade" são referidas por estes autores, sendo que a última estaria relacionada a comportamentos violentos, especialmente entre

1) homens a quem foram negados acesso à masculinidade hegemônica por questões de raça/cor, classe e orientação sexual e 2) homens cuja socialização se deu com outros homens que apresentam uma conformidade exagerada com os papéis tradicionais. (Schraiber et al, 2005b, p.13). 
Analisando estudos sobre a participação dos homens na violência contra a mulher, Schraiber et al (2005b) apontam algumas interpretações, sendo que a maioria reforça a associação entre a construção da masculinidade e a violência. Para alguns a associação estaria no processo de socialização machista; para outros, estaria no princípio simbólico de honra que orienta as ações e expectativas masculinas nos espaços púbico e privado; e para outros autores, estaria na associação entre virilidade e violência.

Mas para a maior parte dos autores levantados por Schraiber et al (2005b) o uso da violência no espaço doméstico é elemento constitutivo das relações afetivo/conjugais, respondendo à necessidade masculina de se reposicionar em momentos de perda (ou ameaça de perda) de poder, autoridade ou honra na relação conjugal. Ou seja, a violência seria expressão da insegurança dos homens ou da não atualização de um padrão hegemônico de masculinidade. Schraiber et al (2005b) observa, com isto, uma transição da teoria do patriarcado para esta outra concepção, que se distancia de categorizações abstratas e visão monolítica sobre homem e mulher.

Couto e Schraiber (2005) ainda acentuam que o processo de socialização que potencializa o envolvimento dos homens em situações de violência circunscreve padrões de comportamento masculinos que incluem o uso de violência como forma de resolução de conflitos nas relações com pessoas que teriam menos poder na escala social (crianças, mulheres, idosos, homossexuais, pessoas mais pobres etc). Já entre os homens de mesma condição social, o uso da violência verbal e física é considerado justo apenas quando os padrões de reciprocidade são quebrados, como 
nos casos em que estão envolvidos referenciais simbólicos-morais de honra, família, trabalho, por exemplo. (Couto e Schraiber, 2005, pp.702-703)

A partir daqui, serão apresentadas as contribuições de Mendes Gonçalves, Schraiber e Peduzzi sobre o trabalho em saúde nas quais este estudo se apóia para pensar o trabalho assistencial dos psicólogos voltado para mulheres em situação de violência. Estas duas últimas autoras compreendem o trabalho em saúde enquanto trabalho, como formulado por Mendes Gonçalves e que será apresentado a seguir.

\section{Sobre o processo de trabalho em saúde}

Mendes Gonçalves $(1992,1994)$ concebe o trabalho em saúde como ação humana intencional que visa transformação na realidade, com finalidade de suprir necessidades humanas, assim como outros trabalhos humanos. Desta forma, o trabalho em saúde se insere no contexto da produção de serviços, sendo a transformação pretendida dirigida às condições de saúde dos indivíduos ou da população.

Este profissional realiza seu trabalho identificando as necessidades de saúde do sujeito ou da população e vislumbrando finalidades para sua intervenção. Ou seja, antevê um resultado de sua ação e com isto, define o objetivo de seu trabalho para aquele caso específico. No trabalho médico, em geral, o objeto de trabalho é o corpo e neste recorte os profissionais atuam e identificam as intervenções possíveis e cabíveis dentro de suas competências.

É trabalho, por fim, porque visa à obtenção de determinados efeitos, busca alterar um estado de coisas estabelecido como carecimento, e ao fazê-lo vale-se das concepções cientificamente elaboradas sobre o corpo para lidar com algo que escapa aos limites anátomo-fisiológicos do corpo, ainda que possa ser assim apreendido: o patológico, enquanto expressão de uma normatividade específica. Em outros 
termos, ao tomar o corpo anátomo-fisiológico como seu objeto, o trabalho médico 'não se restringe precipuamente para o desvendamento das regularidades elaboradas ao nível da ciência biológica, e sim para a obtenção de efeitos específicos, orientados por uma concepção do que é normal ou patológico para o corpo'. (Mendes Gonçalves, 1994, p.57)

Para operar a transformação do objeto no produto antevisto, o trabalhador faz uso de seus instrumentos, escolhendo aqueles mais adequados para alcançar a finalidade prevista. Por instrumentos refere-se aos recursos materiais e de conhecimento teórico e prático, reconhecidos e apropriados pelo profissional como recursos técnicos para a realização da intervenção que é própria de seu trabalho. À composição do saber teórico, com base científica, e o saber oriundo de experiências anteriores, que ocorre em todo ato assistencial, o autor denomina de saber operante.

A articulação intencional entre necessidades identificadas, objeto de intervenção, finalidade e instrumentos compõe a tecnologia assistencial. Por tecnologia, o autor ressalta que não se restringe ao conjunto de instrumentos materiais de trabalho, pois que estes

(...) só têm existência concreta no trabalho enquanto expressarem relações, provisoriamente adequadas, estabelecidas entre os homens e os objetos sobre os quais trabalham, relações cuja adequação não se estabelece por referência à capacidade produtiva ou à eficácia útil dos instrumentos, mas com respeito às relações sociais de produção, organizados conforme as quais os homens então modificam a natureza e a história. (Mendes Gonçalves, 1994, p.16)

A partir destas considerações, pode-se pensar que qualquer serviço e qualquer profissional organizam e planejam suas intervenções conforme a compreensão do objeto de trabalho que pretendem se debruçar e as finalidades antevistas.

No caso das mulheres em situação de violência, o objeto de intervenção não deveria se restringir ao corpo e nem ao campo da Saúde. Cada setor social e cada campo de conhecimento fazem recortes do que seria seu objeto de intervenção, 
sendo, portanto, um objeto parcelar. Parte-se da idéia que o trabalho assistencial com a violência de gênero requer composição de trabalhos parcelares, com saberes e instrumentos diferentes, de setores assistenciais e vinculações institucionais também distintos, para que a intervenção ocorra sobre um objeto integral - a mulher em situação de violência, e por vezes incluindo também as crianças, agressores e demais envolvidos.

Desta forma, a distinção sobre as diversas formas de compreensão do problema da violência de gênero e sobre os diferentes instrumentos utilizados, é importante para poder compreender e refletir sobre as diferentes práticas exercidas pelos profissionais que buscam interferir nas situações de violência. As intervenções dirigidas às mulheres ou às outras pessoas envolvidas na situação de violência são configuradas pela compreensão que os profissionais e os serviços têm sobre o fenômeno e as necessidades destas pessoas. Intervenções, compreensão do fenômeno e necessidades que são moldadas pela cultura historicamente. Ou seja, a partir do que eles identificam como problema de intervenção e necessidade de sua clientela, e dentro do que consideram suas competências técnicas ou suas possibilidades de ação, são definidas as intervenções a serem realizadas. É a partir disto, dos seus conhecimentos teóricos e práticos, técnicos e pessoais e de seus instrumentos concretos de trabalho que o profissional vislumbra uma possível solução e intervenção na situação que identifica como problema. É também a partir da compreensão do fenômeno, do que recorta como problema passível de intervenção, que o serviço faz o recorte de sua clientela, suas ações e diretrizes, planejando e organizando o trabalho assistencial. 
No entanto, para a assistência a situações de violência, não há tecnologia assistencial consolidada, como demonstra a grande diversidade de práticas, finalidades, instrumentos e recortes do objeto.

Para a discussão sobre a tecnologia assistencial voltada às situações de violência de gênero, vale trazer o conceito cunhado por Schraiber (1997) de técnica moral dependente.

\section{Técnica moral dependente}

A violência de gênero configura-se como um tema complexo e sensível para o trabalho de pesquisa e também para a assistência (Schraiber, 2007; Schraiber et al, 2005a). Complexo por ser um problema de múltiplas dimensões, caracterizando-se, da perspectiva da saúde, enquanto objeto médico-social ou transdisciplinar. Exige, desta forma, a composição de saberes diversos, pois que os conhecimentos das disciplinas isoladas são insuficientes para compreender o problema. Há ainda incertezas, divergências e pluralidade na conformação da violência enquanto objeto de pesquisa e de intervenção. A característica sensível deste tema evidencia-se por ser objeto fugidio e instável quanto à sua delimitação para o trabalho de pesquisa e pelas dificuldades na sua visibilização, tanto na produção de pesquisa quanto na assistência. A violência configura-se como uma "dramática vivência de negação do humano", evocando sentimentos de vergonha, humilhação, medos, que caracterizam a tensão e as dificuldades de falar sobre a situação vivida. É uma experiência de violação de direitos, conflitos interpessoais que envolvem rompimentos nas relações de intimidade e confiança, permeados de julgamentos morais e modelos de masculinidade e feminilidade que desqualificam as mulheres no exercício de suas 
subjetividades. A banalização e naturalização destas experiências, muitas vezes internalizadas, estão ligadas aos sentimentos de culpa e desesperança destas mulheres. O caráter sensível está relacionado, portanto, à delicadeza ética das relações interpessoais no desvendamento e identificação do problema, que se colocam para pesquisadores e profissionais da assistência. Somam-se a esta delicadeza os cuidados com relação às situações de urgência e risco de vida, às situações que constituem como primeira revelação da violência vivida e a mobilização emocional do pesquisador ou do profissional pela identificação de também ter sofrido violências ou pelos sentimentos de impotência frente à situação relatada e medo de retaliações do agressor. A revelação da violência exige, desta forma, o estabelecimento de vinculo de confiança e estratégias de segurança para a mulher e para o profissional. (Schraiber, 2007).

Pensando na tecnologia assistencial direcionada às pessoas nestas situações, pode-se dizer que é técnica moral dependente, utilizando o conceito que Schraiber (1997) cunhou a partir de seus estudos sobre a prática médica. Esta autora ressalta que a técnica médica está vinculada à ética, por ser intervenção no humano, porque o ato médico realiza-se sempre na interação. Assim, a intervenção é um exercício de uma moral no trabalho e a realização da ética do trabalho, que tem um duplo caráter: técnico e humano. Quando trata da ética técnica, Schraiber chama a atenção para o fato de que a ação técnica é mediada e definida pelo o que o médico considera melhor para o paciente. Sendo assim, as escolhas técnicas, bem como a condução desta interação - com base nos conhecimentos científicos e nos conhecimentos práticos - são de ordem ética também. E quando trata da ética humana, lembra que na interação médico-paciente estão implicadas a cumplicidade, o reconhecimento 
mútuo da autoridade moral do médico, a confiança, a alienação do paciente do saber sobre sua doença, a personalização da relação de cuidado, e a singularização do ato da intervenção. O grau da dependência - da técnica moral dependente - é relativo ao caráter mais ou menos dialógico, o compartilhamento ou não das decisões, na relação entre médico e paciente. Ou melhor, não levar em conta os aspectos morais que estão implícitos na interação, é descaracterizar o ato médico como técnica moral dependente. Ter consciência desta dependência moral da técnica possibilita ao médico controlar melhor a interferência dos seus julgamentos morais e exercer uma ação mais correta nos cuidados à saúde, tanto na dimensão humana da interação, quanto na eficácia técnica, que são indissociáveis na prática assistencial.

A violência de gênero configura-se como um objeto que exige dos profissionais consciência e clareza das próprias crenças, dos valores morais, dos modelos de gênero e de conjugalidade que lhes orientam, para que julgamentos morais não interfiram negativamente na intervenção, prejudicando o diálogo e a compreensão do conflito do outro. Além disso, há uma diferença hierárquica de saberes e de poder na relação assistencial, que confere ao profissional autoridade moral nas decisões assistenciais, reconhecida tanto pelo profissional quanto pelo paciente/ cliente. No caso das situações de violência de gênero, é importante reconhecer essa autoridade sem desrespeitar a compreensão da clientela sobre o próprio problema, para manter-se na relação de cuidado e evitar a culpabilização dos agredidos e imposição de valores. Nesse sentido, é um tema que evidencia a dimensão ética e moral implicada nas relações interpessoais de assistência.

A autora ainda chama a atenção para um outro duplo da técnica clínica: o caráter tecnológico e o caráter arte. $\mathrm{O}$ primeiro diz respeito à fundamentação da 
técnica nos saberes científicos, reconhecidos pela categoria e pelos pacientes como verdadeiros, e que expressam a intenção de uniformização e garantia da eficácia dos procedimentos por qualquer profissional com a mesma formação, dotando a intervenção de maior objetividade e independência de particularismos. A valorização da ciência é que confere legitimação social - compreensão também compartilhada pelos próprios médicos - da medicina enquanto prática segura e certa. $\mathrm{O}$ segundo caráter, de técnica arte, refere-se à singularidade do ato médico, que impõe a necessidade de uma técnica mais criativa e ajustada às particularidades de cada caso. Criatividade que é alimentada pelo saber prático adquirido com a experiência clínica própria e dos colegas e que atende a uma característica da situação de assistência e cuidado, que é a exigência de solução de demandas, ainda que não haja amparo do conhecimento científico para fazê-lo. É por este caráter de arte que a técnica pode ser atualizada e renovada.

Com relação à violência doméstica contra a mulher, há uma precária base de conhecimento tecnológico para que os profissionais - sejam os psicólogos, sejam os outros profissionais que trabalham com o tema - possam se apoiar na intervenção. A tendência, com isto, é de se apoiarem mais no saber prático e pessoal, na arte da técnica. Por isto e por ser um tema que reflete uma mudança social de valores e de compreensão do que é aceitável e correto nas relações familiares e conjugais, e mesmo dos ideais de homem e mulher, a violência doméstica é um objeto de intervenção que pode evidenciar os julgamentos morais dos profissionais na condução da técnica e exercício da profissão, descaracterizando-se enquanto técnica moral dependente e comprometendo a eficácia do trabalho assistencial. 


\section{O trabalho em equipe multiprofissional}

Para descrever e analisar a inserção dos psicólogos nas equipes de trabalho dos diversos serviços estudados recorreu-se também à tipologia elaborada por Peduzzi $(1998,2001)$ a respeito de equipes multiprofissionais de saúde. A autora formulou a tipologia a partir de uma pesquisa realizada em alguns serviços de saúde do município de São Paulo, utilizando entrevistas com profissionais e observação do cotidiano de trabalho e que teve como objetivos: identificar as evidências empíricas do trabalho coletivo, destacando os aspectos da complementariedade e interdependência e da articulação das ações realizadas pelos diferentes profissionais que o compõem; compreender as relações entre as concepções dos profissionais de saúde sobre o trabalho em equipe multiprofissional e as situações objetivas de trabalho coletivo.

Peduzzi (1998, 2001) distingue dois tipos de equipe: a equipe integração e a equipe agregação, fundamentando-se na teoria de processo de trabalho em saúde de Mendes Gonçalves e na teoria de ação comunicativa de Habermas. Compreende assim,

(...) o trabalho em equipe consiste numa modalidade de trabalho coletivo que se configura na relação recíproca entre as intervenções técnicas e a interação dos agentes. (Peduzzi, 2001, p.103)

O trabalho é composto por duas dimensões interdependentes na prática: enquanto ação racional dirigida a fins, configurando-se como ação instrumental regida por regras técnicas, e como ação estratégica, regida pela intenção de influenciar na definição da situação ou na decisão de outros com quem se relaciona; enquanto interação, o trabalho é agir comunicativo regido por normas consensuais, 
fundando-se no entendimento e reconhecimento mútuo, com fins de coordenar consensualmente os planos de ação (Peduzzi, 2001). Para a autora,

Entende-se que é por meio dessa prática comunicativa, caracterizada pela busca de consensos, que os profissionais podem argüir mutuamente o trabalho cotidiano executado e construir um projeto comum pertinente às necessidades de saúde dos usuários, além de reiterar o projeto técnico já dado, no que se fizer necessário. (Peduzzi, 2001, p.105)

Para o trabalho em equipe, no modo integração, é necessário ter projeto assistencial comum, com distinção do trabalho específico de cada profissional, numa relação dialogada, integrando as ações assistenciais. Peduzzi (1998) ressalta que esta integração não significa equalização dos saberes ou fazeres, nem a submissão das diferenças a uma verdade única e inequívoca. Esta integração dialogada representaria a superação do isolamento e fragmentação dos saberes e disciplinas na atenção à saúde, cuja unidade foi historicamente perdida nas sucessivas divisões de trabalho e especializações. A prática dialogada é, então, necessária para que fique claro o que é esperado de cada profissional, com definição das responsabilidades individuais, ajustando o trabalho conjunto, em direcionamento comum na assistência. Esta prática dialogada requer dos profissionais um movimento ativo e consciente na direção da articulação dos saberes, com identificação das correlações e conexões existentes entre as intervenções técnicas executadas por cada um dos profissionais. Significa compreender que a autonomia técnica não está relacionada com o isolamento $\mathrm{e}$ independência das ações, mas na colaboração para a construção de um projeto comum de intervenção, com flexibilidade na divisão do trabalho. Trata-se, portanto, de uma autonomia técnica, que pressupõe a complementariedade e interdependência dos saberes e das ações especializadas. 
Já na equipe do tipo agrupamento, o trabalho se efetiva com a justaposição de ações e agrupamento dos agentes, sendo que a comunicação entre esses agentes é externa ao trabalho ou estritamente pessoal. Ou seja, a comunicação não se faz para a articulação de ações e recomposição dos trabalhos especializados. Neste tipo de equipe, observa-se que os agentes atuam com autonomia técnica plena ou com ausência de autonomia técnica, com isolamento das ações especializadas, ocorrendo justaposição de ações e não havendo projeto assistencial comum.

No presente estudo, as equipes multiprofissionais nas quais os psicólogos se inserem não se restringem às equipes de saúde, mas também compõem o trabalho com outros profissionais, como assistentes sociais, educadores, policiais e advogados, em serviços do tipo psicossocial, abrigos, policial, jurídico e de orientações básicas. Todos esses serviços prestam assistência à comunidade e por esta característica, foi possível basear-se na tipologia proposta por Peduzzi (1998) para analisar a composição e articulação das equipes multiprofissionais. Não houve a pretensão de classificar os serviços, conforme esta tipologia, pois para isto seria necessário observar a interação entre os profissionais das equipes estudadas e realizar entrevistas em maior profundidade. Apenas a tipologia proposta serviu de referência para analisar as orientações dos documentos normativos e as entrevistas realizadas nos serviços, no sentido de pensar as possibilidades de construção de projeto assistencial comum e a articulação das ações entre os psicólogos e os outros profissionais e entre os serviços. É desta forma que buscou-se compreender a inserção dos psicólogos nos serviços e na rede de assistência a mulheres em situação de violência. 
Note-se que Peduzzi $(1998,2001)$ discute o trabalho em equipe multiprofissional e que suas contribuições serviram como referência para pensar também o trabalho em rede de serviços intersetoriais. Cabe apresentar alguns aspectos da discussão sobre redes sociais, evidenciando as possibilidades de articulação destas conceituações.

\section{Redes sociais e intersetoriais}

O temo rede social, nas ciências sociais, refere-se normalmente a movimentos de fraca institucionalização, descrevendo conjuntos de atores autônomos que se conectam para organizar ações de interesse mútuo, com o objetivo de perpetuar, consolidar e desenvolver atividades de todos. (Marteleto, 2001). De maneira geral, utiliza-se o termo para estudar articulações entre empresas, entre instituições ou organizações sociais ou mesmo de mobilização comunitária em torno de objetivos compartilhados. (Marteleto, 2004, Granovetter, 2003, Emirbayer, apud Marteleto, 2001, OPAS, 1999).

Os estudos sobre redes tomam como foco a relação entre os atores ou grupos de atores (ou pontos, ou "nós"), partindo da comunicação e da circulação de informação na rede, considerando que as relações ocorrem de forma horizontal e dialogada. Pressupõem complementariedade e interdependência das ações e dos atores, ainda que as relações não sejam fortemente institucionalizadas ou formalizadas. Há valorização dos elos informais e das relações, em detrimento das estruturas hierárquicas.

O que é novo no trabalho em redes de conexões é sua promessa como uma forma global de organização com raízes na participação individual. Uma forma que reconhece a independência enquanto apóia a interdependência. (Lipnack e Stamps, 1992, apud Marteleto, 2001) 
A Organização Panamericana de Saúde (1999) compreende que a rede de ações sociais é uma das estratégias necessárias para o enfrentamento da violência intrafamiliar e a violência contra as mulheres. Quando tratam de redes de ação referem-se à associação entre instituições ou organizações que buscam a satisfação de necessidades sociais, baseados em valores como solidariedade para a transformação de determinada situação social.

Las redes pueden definirse como conjuntos de vínculos o interacciones entre personas $u$ organizaciones. Sirven para coordinar pensamientos y acciones y se crean a partir de la existencia de esquemas de prioridades compartidos, es decir con base en relaciones entre individuos que participan en ella. Se trata de un tejido de relaciones e interacciones que se construyen con una finalidad y se interconectan a través de intercambios, líneas de trajo conjunto entre individuos, grupos, países, etc. existen redes primarias y otras que provienen de decisiones voluntarias explicitas de los participantes. (OPAS, 1999, p. 6)

O que denominam de redes primárias são as articulações de ações mais espontâneas e com baixa institucionalização, como por exemplo, as relações familiares. Entendem que as redes sociais de ação caracterizam-se pela relação horizontal de seus membros, a ação voluntária, a interdisciplinariedade, a cooperação, a flexibilidade, a solidariedade, a ação sobre um único tema, e a formalização conceitual sobre os objetivos, os fins e os meios aplicados na rede. São redes mais burocratizadas do que as redes primárias no sentido que existe planejamento, regulamentação acordada, bem como processos de execução e avaliação.

Com relação às redes de enfrentamento às situações de violência intrafamiliar, a OPAS refere-se às relações articuladas de movimentos sociais, entre indivíduos, serviços e organizações governamentais e não governamentais. Estas 
redes teriam como objetivos reduzir a violência intrafamiliar; mobilizar recursos institucionais para assistência, prevenção e tomada de consciência das situações de violência; promover a socialização e intercambio de propostas, planos e programas de ação entre as instituições e organizações; e criar e formalizar instâncias de coordenação das ações. Pensam a consolidação destas redes de maneira organizada e institucionalizada, portanto.

O presente estudo restringiu-se a um conjunto de serviços de setores sociais diversos (segurança pública, saúde, assistência social), voltados para a assistência a mulheres em situação de violência. Partiu-se da compreensão de rede intersetorial como

(...) a articulação objetiva das ações interinstitucionais e a interação entre seus agentes, além da presença de canais definidos de comunicação entre os serviços que compõem o conjunto e potencialmente participariam da rede. (Kiss, 2007)

Utilizou-se, portanto, a contribuição de Peduzzi (1998) sobre o trabalho em equipes multiprofissionais.

Na pesquisa sobre redes que é ponto de partida deste estudo (D'Oliveira e Schraiber, 2006), observou-se que os serviços pesquisados articulam-se tanto com outros serviços também específicos (exclusivamente voltados para o tema, ou com programas ou ações específicas), como com serviços da comunidade, que foram denominados como rede geral (conselhos tutelares, escolas, serviços de assistência social, programas de inclusão no trabalho, igrejas, delegacias de policia comuns, entre outros que não definiram ações específicas para atender à demanda de violência).

Nessa pesquisa, os serviços específicos foram categorizados por vocação assistencial, a saber: policial, jurídico, saúde, orientações básicas, psicossocial e 
abrigo. Para identificação das vocações assistenciais, foram utilizados os dados fornecidos pelos entrevistados (gerentes e profissionais da assistência) sobre as atividades desenvolvidas, a equipe técnica e os objetivos do serviço.

Priorizou-se a vocação assistencial de cada serviço, independente da vinculação institucional e do setor social a que pertence, pois a intenção foi de fazer uma análise da rede de serviços. Para tanto, considerou-se mais interessante o tipo de assistência oferecido e a assistência que seria complementar para o trabalho de cada um. Por isto não foi utilizado o termo Centro de Referência, que foi categorizado na maior parte das vezes como Psicossocial. Também foi criada a categoria Orientações Básicas, que nos serviços estudados eram principalmente serviços de saúde e serviços jurídicos que oferecem acolhimento e orientações gerais para situações de violência, encaminhando para outros serviços para realizar o atendimento e seguimento específico.

Nessa pesquisa, concluiu-se que as interações entre os serviços ainda são muito precárias, configurando-se como uma trama e não como rede.

A rede, diferentemente do sistema, é horizontal, monta tramas diversas a partir das necessidades dos casos e do conhecimento de seus agentes, não tem comando único nem porta de entrada e fluxos sistematizados. Além disto, o mesmo ator (no caso, os serviços) pode participar de várias redes simultaneamente. (D’Oliveira e Schraiber, 2006, p. 9)

Trama pode ser definida como um:

(...) aglomerado justaposto de serviços voltados ao mesmo problema, que podem até possuir ações articuladas, mas sem consciência de suas conexões e sem construção de projeto assistencial comum construído pelo diálogo. (D’Oliveira e Schraiber, 2006, p.10)

Observou-se que a trama de serviços especializados estudada é instável e fragmentada. Instável pela dificuldade em sustentar equipes e programas, 
principalmente nos serviços governamentais, cujas diretrizes são alteradas conforme a sucessão dos governantes. Fragmentada pela baixa articulação de ações entre serviços de vocações assistenciais diferentes e desconhecimento mútuo, realizando e recebendo poucos encaminhamentos de muitos dos serviços. Notou-se uma conexão entre os serviços jurídicos e policiais, que têm pouca relação com os serviços dos outros setores. Os serviços de saúde conectam-se mais com outros serviços de saúde, além dos psicossociais. Já estes últimos parecem articular suas ações com todos os outros setores, ocupando o "centro" desta trama. No nosso estudo, procuramos analisar como os psicólogos se inserem nesta trama.

Considerou-se, ainda, que há grandes diferenças quanto às culturas institucionais dos setores aos quais os serviços estão vinculados e há diferenças (intra e entre os setores sociais) e divergências na concepção do objeto e dos instrumentos de intervenção. Além disso, considerou-se que o reconhecimento da necessidade de articulação em rede é recente, bem como é recente o conhecimento dos problemas de integração e ação conjunta. Para alguns serviços, ainda, a própria consciência e a sensibilização sobre a violência contra a mulher são recentes e ainda não consolidaram propostas de intervenção. Era de se esperar que a rede ainda não estivesse constituída.

Note-se que estão compostos o conceito de rede com a tipologia proposta por Peduzzi a respeito do trabalho em equipe multiprofissional e a compreensão sobre trabalho enquanto interação entre os agentes e articulação de ações. Assim, para o trabalho articulado em rede, pressupõe-se a compreensão de que a violência de gênero é um problema multidimensional e exige a composição de trabalhos parcelares para uma atenção integral às mulheres em situação de violência, através da 
articulação de ações assistenciais de vocações diversas. Pressupõe-se, ainda, que o trabalho integrado exige um projeto assistencial comum, concretizado na interação dialógica entre os agentes e com articulação de ações assistenciais de forma interdependente e complementar, considerando a autonomia técnica de cada agente e a composição de saberes de disciplinas diferentes. Já numa trama de serviços, o trabalho se caracteriza pela justaposição de ações, sem necessariamente a interação entre os agentes, nem articulação de ações na direção de um projeto assistencial comum.

Considerando as características de diversidade e ecletismo das práticas psicológicas, apontadas por diversos autores (Figueiredo, 2001; Carone, 2003; Schmidt, 1999), e as tendências à psicologização, despolitização e despublicização das práticas psicológicas brasileiras com relação ao tema violência, como aponta Coimbra (1995), pode-se pensar que estes profissionais têm dificuldades quanto à articulação de ações, integração e comunicação com os profissionais de outras formações. Divergências internas à psicologia e entre as diferentes disciplinas possivelmente podem comprometer a definição e compreensão do trabalho do psicólogo, e consequentemente, de sua autonomia técnica. Indefinições a respeito do que é próprio e do que é comum aos profissionais nas tarefas assistenciais dificultam a articulação de ações, a comunicação e a construção de um projeto assistencial comum.

O caráter incipiente da rede de serviços estudada faz pensar em alguns aspectos das dificuldades dos profissionais na assistência às situações de violência contra a mulher: se já é difícil trabalhar em equipe de forma realmente integrada, comunicativa, com projeto comum dentro de uma mesma instituição ou de serviços 
de mesma vocação assistencial, com outros serviços de vocações assistenciais diferentes, provavelmente ampliam-se as dificuldades na comunicação, em função das diferenças de linguagem, de canais de comunicação, de finalidade/ objetivo das ações, e também de objeto. Assim, por exemplo: na Saúde, há um consenso de que se atua sobre os problemas de doença, ou promovendo a saúde - se não há repercussão em termos de adoecimento, em geral os profissionais entendem que não é da sua esfera de atuação. De forma semelhante, nos serviços policiais, o que não é percebido como objeto de intervenção não compete a estes profissionais e instituição. Assim, as policiais agem sobre o crime, e por isso, em geral o que não é crime, passível de registro, investigação e punição não lhes parece um objeto de intervenção que lhes compete. Os serviços voltados para atender mulheres em situação de violência, além de fazerem recortes diferentes sobre o objeto de intervenção, com compreensões talvez divergentes sobre o problema, pertencem a setores sociais com linguagens próprias, são serviços e equipes independentes, não compartilham da mesma hierarquia profissional, não tem canais de comunicação compartilhados e nem estão fadados ou planejam trabalharem juntos. Neste contexto, a comunicação é fundamental para a construção de projeto assistencial comum, que exista mobilização dos profissionais para compreender o trabalho - as ações, propostas, limites - do outro e então compor um trabalho integrado, entre serviços de vocações diferentes, de forma que cada um complemente a intervenção do outro. Promover e manter essa integração são tarefas e um desafio que aparentemente as propostas de redes de serviços buscam realizar.

É nessa dificuldade de integração e comunicação que os encaminhamentos para outros profissionais aparecem não como articulação de trabalhos, numa 
perspectiva de trabalho conjunto, projeto comum, mas de sobreposição e justaposição de ações, com precária comunicação e conhecimento do trabalho do outro. É o mecanismo de passar a "batata quente", ou livrar-se do problema, considerando que "ele não é da minha competência".

É interessante problematizar mais um pouco. Atualmente o enfrentamento da violência contra a mulher tem envolvido profissionais dos serviços e da universidade, vinculados ou não com o movimento feminista. Com isto, temos um quadro de profissionais nos serviços governamentais e não governamentais que atendem situações de violência com diferentes concepções: desde as feministas ou pessoas que concordam com o referencial feminista, até os que os desconhecem e também aqueles que discordam deste referencial. São profissionais que não necessariamente estavam envolvidos com as questões feministas e também não necessariamente escolheram trabalhar com o tema. Isto ocorre especialmente nos serviços governamentais, onde cargos, atribuições e projetos são designados e nem sempre há possibilidade de escolha para o profissional.

Cabe lembrar que mudanças culturais nos padrões das relações de gênero, como qualquer mudança cultural, são graduais e lentas, sendo que os sujeitos internalizam, questionam e transformam os valores de maneiras diferenciadas e em tempos diversos. Entre os profissionais dos serviços não é diferente, uma vez que também são sujeitos inseridos na mesma cultura. No atual contexto dos serviços vêse que há, entre muitos dos profissionais, em sua maioria mulheres, a permanência da concepção tradicional de relação entre homens e mulheres, mesmo entre os profissionais "especializados", que justificam e aceitam a desigualdade de poder nas relações e não compreendem como uma questão de desigualdade de direitos ou 
mesmo de violação de direitos da mulher. Divergências na percepção e concepção sobre o tema entre os profissionais podem representar dificuldades para o diálogo entre eles e com outros serviços, e também para a elaboração de projetos assistenciais comuns. Nesse sentido, a posição das contribuições da perspectiva feminista sobre o fenômeno da violência de gênero é importante para a definição do objeto de intervenção e consequentemente, para a organização das ações assistenciais. O problema da violência contra as mulheres pode ser compreendido tanto como violência de gênero e um problema de direitos humanos, quanto, num outro extremo, como um problema de desajuste familiar ou individual (do agressor ou da mulher). Lembrando as considerações de Coimbra (2002), os psicólogos brasileiros tendem a tratar a violência pelos seus aspectos individuais, intrapsíquicos, psicológico-existenciais e familiares. Este posicionamento provavelmente traz dificuldades de articulação e comunicação, especialmente por ignorar a concepção da violência enquanto violação dos direitos, com base na desigualdade de gênero. A integração, na prática, das dimensões subjetivas e políticas talvez configurem como um dos desafios para este profissional. 


\section{Capitulo 4 - O Desenho e o Campo da Pesquisa}

Para atingir os objetivos, foram realizados:

- Levantamento e análise de documentos de orientação para a prática profissional do Ministério da Saúde e da Secretaria Especial de Políticas para as Mulheres, sobre a presença e as ações previstas para os psicólogos nos serviços específicos;

- Mapeamento da distribuição dos psicólogos nos serviços voltados para o atendimento a mulheres e meninas em situação de violência, da região metropolitana de São Paulo;

- Análise da inserção dos psicólogos conforme o tipo de serviço, com descrição das equipes, das propostas assistenciais, das atividades desenvolvidas pelos psicólogos e considerações dos entrevistados sobre o conhecimento da rede de serviços e os encaminhamentos que costumam realizar e receber.

O presente estudo utilizou parte do material da pesquisa "Identificando possibilidades e limites do trabalho em rede para a redução da violência contra a mulher: estudo em três capitais brasileiras”, sob coordenação das Profas. Ana Flávia P. L. D’Oliveira e Lilia Blima Schraiber, do Departamento de Medicina Preventiva da Faculdade de Medicina da Universidade de São Paulo, financiada pelo Ministério da Justiça e em parceria com SOS Gênero e Cidadania e Themis Assessoria Jurídica e Estudos de Gênero no qual a autora desta dissertação foi componente da equipe de pesquisadores e supervisora de campo em São Paulo. Este estudo, chamado aqui "estudo sobre redes", foi realizado em 2005 nas regiões metropolitanas de São Paulo, Recife e Porto Alegre. Teve como objetivo mapear e 
descrever os serviços de diversos setores sociais que atendem mulheres e meninas em situação de violência, identificando sua vocação assistencial, fluxo assistencial e interconexões, dificuldades e sucessos no trabalho em rede. Para isto foram entrevistados, com questionário semi-estruturado, um profissional da assistência e um gerente de cada serviço específico no atendimento à violência contra mulheres e adolescentes.

A partir dos dados obtidos neste estudo, foram identificados aqueles serviços da região metropolitana de São Paulo que contavam com atividades assistenciais realizadas por psicólogos. Com esta população de serviços, foi realizado um mapeamento da distribuição e inserção dos psicólogos, utilizando as seguintes informações colhidas na pesquisa sobre redes:

Caracterização da equipe assistencial (quantidade, formação, função)

$\checkmark$ Descrição das atividades assistenciais em geral

$\checkmark$ Descrição das atividades dos psicólogos

Relatos da articulação do trabalho entre os diversos profissionais da equipe

Relatos da articulação do trabalho com outros serviços

\section{Considerações éticas}

As entrevistas foram realizadas com gerentes e profissionais da assistência que voluntariamente se dispuseram a contribuir com o estudo, após esclarecimento dos objetivos e da utilização das informações, assegurando o sigilo da identificação e com assinatura de consentimento informado (Anexos C e D). Procurou-se realizar as entrevistas em espaços que garantissem a privacidade, dentro do próprio serviço. A condução do estudo teve como norteador o respeito ao trabalho desenvolvido 
pelos profissionais, visando à compreensão sobre as práticas assistenciais e a contribuição para uma melhor articulação do trabalho multiprofissional e intersetorial dos profissionais e serviços.

Antes da realização do campo, o projeto de pesquisa foi aprovado pela Comissão de Ética para Análise de Projetos de Pesquisa - CAPPesq da Diretoria Clínica do Hospital das Clínicas e da Faculdade de Medicina da Universidade de São Paulo em 13.10.04, sob o protocolo de pesquisa n. 779/04. (Anexo A).

Em São Paulo também foi necessária a aprovação pelo Comitê de Ética da Secretaria Municipal de Saúde de São Paulo, para a realização da pesquisa junto aos serviços municipais de saúde (Unidades Básicas, CRT/ DST-AIDS, hospitais, ambulatórios), sob o protocolo CEPSMS 0105/2005, CAAE 0050/2005. (Anexo B). Além disso, a coordenação dos serviços de DST/AIDS solicitou reunião para apresentação da pesquisa junto aos gerentes dos serviços, visando esclarecer os objetivos e procedimentos do estudo, para que então cada um pudesse manifestar o interesse e a permissão para a realização da pesquisa na sua unidade. Após a finalização da pesquisa, em 2006, os resultados e analise foram apresentados aos gerentes dos serviços, em reunião na Secretaria Municipal de Saúde.

As autorizações para a pesquisa pela Assessoria das DDMs de São Paulo, pela Procuradoria de Assistência Judiciária, pela OAB/SP e Coordenadorias da Mulher dos municípios da Grande São Paulo também foram fornecidas, por meio de mensagem de e-mail ou contato telefônico. Os mesmos procedimentos foram efetuados junto à direção das organizações não governamentais (ong’s) e serviços jurídicos vinculados a universidades. 


\section{Levantamento dos documentos}

Para identificar a inserção prevista para os psicólogos nos serviços voltados para o atendimento a mulheres em situação de violência, levantaram-se orientações para o trabalho assistencial (com ênfase para o papel do psicólogo) sobre o tema em documentos oficiais. Foram encontrados documentos do Ministério da Saúde e da Secretaria Especial de Políticas para Mulheres. Os documentos estudados foram os seguintes:

Lista 1. Lista de documentos normativos estudados

\begin{tabular}{|c|c|}
\hline \multirow[t]{3}{*}{ Ministério da Saúde } & $\begin{array}{l}\text { Prevenção e Tratamento dos Agravos Resultantes da } \\
\text { Violência Sexual contra Mulheres e Adolescentes: norma } \\
\text { técnica. } 2^{\mathrm{a}} \text { ed. atualizada e ampliada. } 2005 \text {. }\end{array}$ \\
\hline & Atenção Humanizada ao Abortamento: norma técnica. 2005. \\
\hline & $\begin{array}{l}\text { Violência Intrafamiliar: orientações para prática em serviço. } \\
\text { Série Cadernos de Atenção Básica } \text { n }^{\circ} 8.2001 .\end{array}$ \\
\hline \multirow[t]{2}{*}{ SPM } & $\begin{array}{l}\text { Norma técnica de uniformização - Centros de Referencia de } \\
\text { Atendimento a Mulher em Situação de Violência. } 2006 \text {. }\end{array}$ \\
\hline & $\begin{array}{l}\text { Programa de Prevenção, Assistência e Combate à Violência } \\
\text { Contra a Mulher - Plano Nacional: diálogos sobre violência } \\
\text { doméstica e de gênero: construindo políticas públicas. } 2003 \text {. }\end{array}$ \\
\hline SPM e SENASP & $\begin{array}{l}\text { Norma técnica de padronização - Delegacias Especializadas } \\
\text { de Atendimento à Mulher - DEAMs. } 2006 .\end{array}$ \\
\hline
\end{tabular}

A publicação de 2003 da Secretaria Especial de Políticas para as Mulheres (SPM) estabelece um protocolo para implementação de casas-abrigo. A norma técnica de padronização para DEAMs (2006a) foi elaborada em conjunto com a Secretaria Nacional de Segurança Pública (SENASP). 


\section{Serviços estudados}

Para a seleção dos serviços paulistas pesquisados no estudo sobre redes, partiu-se de uma lista inicial de 91 serviços que constam no Guia de Serviços, publicado em 2002. Antes e durante o campo da pesquisa, foram incluídos outros serviços, identificados de várias formas: pelo relato dos entrevistados, informação e indicação das chefias centrais dos serviços e sites relacionados, totalizando 156 serviços.

Os critérios de escolha dos serviços, na pesquisa sobre redes foram:

- serviços instalados na região metropolitana;

- serviços com porta aberta para a população, ou seja, que as mulheres e adolescentes pudessem acessar espontaneamente;

- serviços voltados para o atendimento específico de mulheres e/ou adolescentes que vivem ou viveram violência de gênero (violência doméstica e/ou violência sexual, incluindo hospitais que realizam aborto legal), que se reconhecem como referência para o tema, com organização específica da assistência para esta clientela (equipe, fluxo, atividades, e/ou protocolos específicos).

- serviços que não são exclusivamente voltados para o tema, como CRT/DSTAIDS, ong's voltadas para outras demandas, mas que desenvolvem ações específicas para essa clientela.

- serviços de assistência jurídica com porta aberta para a população, que no geral não se reconhecem como referência para o tema, nem organizam suas ações para essa clientela específica. Somente alguns reconhecem a violência doméstica como uma demanda importante da sua clientela. Estes serviços foram incluídos na pesquisa pela importância do tipo de assistência no enfrentamento 
do problema e especialmente porque, apesar de em sua maior parte não se reconhecerem como parte da rede, foram bastante citados pelos outros serviços estudados.

Foram excluídos os serviços voltados para crianças que sofreram/ sofrem violência doméstica e/ou sexual, por serem muitos e constituírem rede diferenciada. Somente alguns deles foram incluídos na pesquisa, por atenderem adolescentes.

Também foram excluídos serviços que foram extintos ou tiveram suas atividades alteradas e não se enquadravam mais nos critérios da pesquisa (não ter porta aberta, não atender situações de violência de gênero, não oferecer mais assistência à população), ou por recusa em participar da pesquisa ou do Guia de Serviço.

Vale salientar que os serviços de saúde da capital foram os de mais difícil seleção e contato. Alguns deles não reconheciam o desenvolvimento de alguma atividade específica à violência, mesmo quando divulgados no site da prefeitura de São Paulo como especializados em violência sexual e/ou Aborto Legal. Pôde-se observar que havia nas listas iniciais um total de 30 serviços de saúde divulgados como referência para violência, sendo que 16 deles não foram incluídos na pesquisa por motivos já citados.

Um dos objetivos da pesquisa sobre redes foi a produção de uma nova versão do Guia de Serviços para Mulheres em Situação de Violência. Por este motivo, foram feitas algumas entrevistas com roteiro menor com alguns serviços, somente para obter informações pertinentes à inclusão no Guia de Serviços. Este grupo de serviços é composto principalmente por instituições de assistência jurídica 
de São Paulo com várias unidades de atendimento (núcleo jurídico de Faculdades de Direito e das unidades da $\mathrm{OAB} / \mathrm{SP}$ ), cujo fluxo e organização do serviço, bem como objetivos e equipe são muito semelhantes entre as unidades. As entrevistas com profissionais e coordenação nas sedes de cada Faculdade mostraram-se suficientes para a pesquisa. Foi observado durante o campo que as entrevistas junto aos serviços jurídicos, especialmente dos Núcleos de Assistência Jurídica das faculdades de Direito e das unidades da OAB, apresentaram resultados bastante similares, tanto na organização da assistência, quanto na relação e conhecimento da rede de serviços. Por serem serviços que não se reconhecem como específicos no trabalho com situações de violência, a coordenação da pesquisa decidiu utilizar o critério de saturação das entrevistas e contatar os serviços restantes somente para inclusão no Guia.

Ao final, foram realizadas entrevistas completas com 115 serviços da região metropolitana de São Paulo e foram obtidos 127 endereços integrados na versão final do Guia São Paulo (82 deles constam do Guia do Município de São Paulo e 42 são do Guia da Grande São Paulo. Além destes serviços, constam nos dois guias três serviços de orientação por telefone).

Alguns serviços (06) contatados não se adequaram aos critérios da pesquisa, por dedicarem-se a atividades de investigação e denúncia de crimes contra mulheres; ou desenvolverem trabalho assistencial somente com crianças; ou não atuarem com violência contra mulheres, mas oferecem outras atividades relacionadas. Estes serviços foram incluídos no Guia de Serviços e classificados como Outros, pela sua importância como suporte para a rede.

Para o presente estudo, foram utilizadas informações referentes às 
entrevistas válidas de $\mathbf{1 0 9}$ serviços, excluindo aqueles 6 classificados como Outros. Destes 109 serviços paulistas, $\mathbf{5 6}$ contavam, no segundo semestre de 2005 (época de realização do trabalho de campo), com psicólogos na equipe, desenvolvendo atividades assistenciais diversas, como pode ser visto no capítulo 5. A análise centrou-se nos 56 serviços que têm psicólogos na equipe.

\section{Questionário}

O questionário foi elaborado a partir da versão utilizada para a confecção da primeira edição (de 1996) do Guia de Serviços: Mulheres em Situação de Violência. Nessa versão, o questionário continha perguntas sobre a caracterização do serviço: atividades desenvolvidas, fluxo assistencial, equipe. Foram acrescidas perguntas sobre os encaminhamentos recebidos e realizados. O questionário foi elaborado para ser respondido em duas partes: uma primeira pelo gerente da unidade, com questões de caracterização do serviço, da clientela e sobre o conhecimento de outros serviços da rede; a segunda a ser respondida por um profissional da assistência, com mais detalhes sobre as atividades assistenciais, com relato de casos típicos e atípicos, e maiores detalhes sobre a relação com a rede de serviços. (Anexo E).

\section{O campo da pesquisa}

Para a realização do campo em São Paulo, foi formada uma equipe de 10 entrevistadores contratados e treinados, e 2 supervisoras de campo.

Antes do início do campo, foram realizados seleção dos entrevistadores e treinamento dos aprovados. O treinamento consistiu em apresentação de conceitos e 
discussão sobre gênero, violência e rede de serviços, além de leitura e aplicação dos questionários entre os participantes, com duração de 12 horas.

O campo de São Paulo iniciou em 02/06/2005 e teve duração de 4 meses.

Para a preparação do campo, as supervisoras realizaram contato prévio com as instituições solicitando autorização para a pesquisa, através de ofícios e contatos telefônicos. Em algumas instituições foi necessária autorização do nível central (Secretaria Municipal da Saúde, Assessoria das DDMs, Procuradoria de Assistência Judiciária).

As entrevistas foram realizadas nos serviços, em local reservado para garantir o sigilo das informações, e tiveram duração média de 2,5 horas, sendo 1 hora com a gerência (parte 1 do questionário) e 1,5 horas com o profissional da assistência (parte 2 do questionário). Este tempo foi maior do que o previsto, especialmente pelas constantes interrupções. Como as entrevistas foram realizadas nos serviços, a maioria no horário de trabalho dos profissionais, as interrupções para atender demandas institucionais foram freqüentes. Os profissionais também demonstraram ansiedade para contar sobre o seu trabalho, o que expressou - segundo opinião dos entrevistadores - a necessidade de supervisão e reconhecimento do trabalho realizado. A demanda por supervisão é relatada pelos profissionais da assistência durante as entrevistas.

Todas as entrevistas foram revistas pelas supervisoras de campo, e quando necessário, os entrevistadores realizaram novos contatos (por telefone ou com novas visitas aos serviços) com os profissionais dos serviços para esclarecimentos e/ou para completar as informações. 
Os entrevistadores se depararam com algumas dificuldades durante a realização do campo, quais sejam:

- Agendamento de horários para entrevista com os profissionais nos serviços, especialmente com os coordenadores/ gerentes.

- Precariedade ou inexistência de dados em alguns serviços, sobretudo a respeito dos dados sobre a clientela e o atendimento (volume de demanda, perfil da clientela, proporção de atendimento de homens/ mulheres/ crianças). Muitos serviços não dispunham destas informações sistematizadas e em alguns, os profissionais não estavam autorizados a fornecer estes dados.

- Serviços em reestruturação da equipe assistencial e da proposta de trabalho, o que dificultou não só a localização dos profissionais a serem entrevistados, como as informações sobre o trabalho realizado.

Vale salientar que as entrevistas foram realizadas com gerentes (parte 1 do questionário) e com profissionais da assistência (parte 2 do questionário), que se dispuseram a participar da pesquisa e que - com indicação ou não da coordenação do serviço - foram identificados como melhores informantes sobre o serviço. Poucos psicólogos foram entrevistados: somente 19 responderam ao questionário, sendo 1 em serviço jurídico, 1 em policial, 3 em serviços de orientação básica, 8 em psicossociais, 5 em serviços de saúde e 1 em abrigo. Desta forma, os dados sobre o trabalho assistencial - incluindo o trabalho do psicólogo -, na grande maioria das vezes, não foram fornecidos pelos próprios, mas principalmente por assistentes sociais, mas também por advogados/ promotores, policiais (escrivãs) e médicos. A instrução para a identificação do melhor informante para a parte 2 do questionário foi ter bom conhecimento sobre o serviço, sobre o fluxo assistencial, bem como sobre a 
os encaminhamentos realizados para a rede de serviços. A baixa participação dos psicólogos enquanto informantes ocorreu provavelmente porque não eram os profissionais que realizavam os encaminhamentos da clientela (em geral é a assistente social) e talvez porque não sejam os profissionais mais apropriados para informar sobre os fluxos assistenciais dos serviços nos quais estavam inseridos. Isto pode ser uma indicação de baixa integração deste tipo de profissional nas equipes. 


\section{CAPITUlo 5 - Resultados E discussão}

PARTE 1 - O PSICOLOGO E A REDE DE ASSISTENCIA: NORMAS E PROTOCOLOS

Nos protocolos da SPM e do MS encontrados, o trabalho do psicólogo estava previsto nas DEAMs, nos abrigos, centros de referência e nos serviços de saúde que prestam assistência a situações de violência sexual - incluindo a assistência aos casos de gravidez decorrente de estupro.

Vale lembrar que os documentos normativos espelham concepções e diretrizes políticas oficiais e tendem a fornecer orientações gerais para a implantação de serviços e para a prática dos profissionais. No tema em questão, a violência contra a mulher, há forte penetração do movimento de mulheres no governo federal, principalmente a partir da última década. As concepções e diretrizes têm, portanto, influência das reivindicações feministas com relação à construção de uma política pública de enfrentamento ao problema.

No caso das Normas Técnicas do Ministério da Saúde, voltadas para situações de violência sexual e realização do aborto previsto em lei, são prescrições normativas principalmente para a prática médica e, no aspecto biomédico, são extremamente detalhadas, definindo métodos, medicações e procedimentos para a intervenção. Estas normas e o protocolo para atenção básica, quando tratam da tecnologia que diz respeito à interação entre profissional e paciente, sugerem posturas e delineiam princípios para a assistência. Os protocolos e normas da SPM dispõem sobre a estrutura e organização dos serviços, recursos humanos, objetivos, fluxos de atendimento, atribuições de cada profissional, sugerindo ainda fichas e 
formulários de registro e encaminhamento. São orientações que buscam uniformização e padronização dos serviços. Delimitam princípios gerais para a assistência, mas sua concretização depende da política local e das condições de trabalho. Levando em consideração que as condições locais são diversas, a aplicação destas orientações provavelmente também será desigual, ajustadas às particularidades de cada região e instituição. Desta forma, não são documentos somente técnicos, mas com importante dimensão política.

A violência contra as mulheres é um tema polêmico, complexo e novo para a assistência em geral, no sentido de que ainda não há tecnologia assistencial consolidada. Portanto, é preciso considerar que há uma distância entre as orientações e as práticas dos serviços. Em certa medida, esta distância sempre existirá, pois a prática assistencial se baseia também na experiência dos profissionais e o atendimento se realiza na interação com o cliente/paciente. Ou seja, a assistência ajusta-se e aprimora-se na relação assistencial. Desta forma, não é possível definir em detalhes todo o conteúdo interno do trabalho de cada profissional, sob o risco de engessar a prática e desconsiderar o saber prático e a maneira de interagir de cada um.

Com relação à violência de gênero, por ser um tema novo e que implica em mudanças de valores sociais, acrescentamos que estas orientações oficiais constituíram tentativas de implantar políticas públicas de assistência. Podemos dizer que representam conquistas no enfrentamento à violência de gênero, já que no geral reconheceram o fenômeno, a necessidade de prestar assistência, de desenvolver tecnologia assistencial e o fizeram na perspectiva de gênero e na afirmação dos direitos das mulheres. Responderam, em grande parte, às reivindicações do 
movimento feminista e podemos dizer que contribuem para a construção de um objeto e um projeto comuns para a assistência nos diversos serviços voltados para o problema.

\section{A - Do apoio aos profissionais}

O apoio, capacitação e supervisão para os profissionais que prestam assistência a situações de violência foram necessidades reconhecidas nas normas e protocolos encontrados. No entanto, diferente do que foi encontrado na revisão bibliográfica, não estavam necessariamente relacionadas ao trabalho do psicólogo.

Chama a atenção que, para os formuladores das políticas, diferentemente das policiais das DEAMs (Silva, 2002) e da equipe do abrigo mineiro (Alves e Coura Filho, 2001) o reconhecimento do impacto emocional do trabalho não pressupôs apoio psicológico para os profissionais, mas se traduziu em necessidade de capacitação e supervisão continuada, como foi observado nas NT para atendimento à violência sexual (Ministério da Saúde, 2005a) e aborto humanizado (Ministério da Saúde, 2005b), na proposta para a atenção básica (Ministério da Saúde, 2001), no protocolo para abrigos (SPM, 2003), e nas normas técnicas para Centros de Referência (SPM, 2006b). Diferente da proposta de alguns psicólogos (Willians et al, 2000), as normas e protocolos não indicavam profissionais específicos para conduzir esta capacitação.

A SPM, quando dispôs sobre o padrão mínimo de implementação dos abrigos, nos comentários sobre os recursos humanos, argumentou:

A constituição e o fortalecimento de uma equipe interdisciplinar está vinculada ao desenvolvimento de estratégias de ação que qualifiquem os profissionais $e$ os preparem para um acolhimento $e$ abordagem humanizada, baseada em condutas adequadas e informadas pelos 
aspectos éticos e de compromisso com o resgate da auto-estima e cidadania de cada uma das pessoas atendidas. Para isso é necessário um programa permanente de capacitação, promovendo o conhecimento e a adesão do profissional à metodologia da abordagem, e permitindo que as vivências e frustrações pessoais possam ser elaboradas de forma saudável no coletivo da equipe. $O$ diálogo entre os profissionais de diferentes formações e habilidades é essencial para a integração e a unidade dos procedimentos $e$ orientações. A prática interdisciplinar exige a divisão de tarefas e a percepção dos limites e competências de cada profissional, valorizando a liderança e o desenvolvimento de novos conhecimentos no processo de atendimento dos casos. A avaliação periódica deve ser adotada tanto como estratégia da equipe, para enfocar e sustentar uma orientação coletiva, como a avaliação através de supervisão técnica e mecanismos de controle social. (SPM, 2003, p.61 - grifos nossos)

Com a mesma compreensão, o Ministério da Saúde preconizou, na NT de

Prevenção e Tratamento aos Agravos Resultantes da Violência Sexual contra

Mulheres e Adolescentes, de 2005:

(..) há que se promover, sistematicamente, oficinas, grupos de discussão, cursos, ou outras atividades de capacitação e atualização dos profissionais. Isso é importante para ampliar conhecimentos, trocar experiências e percepções, discutir preconceitos, explorar os sentimentos de cada um em relação a temas com os quais lidam diariamente em serviço, a exemplo da violência sexual e do abortamento, buscando compreender e melhor enfrentar possiveis dificuldades pessoais ou coletivas. Isso porque, ao lidar com situações de violência, cada profissional experimenta sentimentos $e$ emoções que precisam ser reconhecidos e trabalhados em função da qualidade do atendimento e do bem-estar do(a) profissional envolvido(a). (MS, 2005a, p.22, grifos nossos).

E na proposta para a atenção básica, de 2001, constava uma orientação aos profissionais para que estivessem atentos e conscientes para este impacto da violência:

A violência intrafamiliar afeta a todos que, de alguma forma, se envolvem com ela, e os profissionais da saúde não são exceção. $O$ contato com situações de sofrimento e risco a insegurança e os questionamentos que desperta, bem como a impotência em obter 
soluções imediatas, exigem um tempo de autodedicação para proteção e alivio de tensões. Por este motivo, é preciso criar oportunidades sistemáticas de discussão, sensibilização e capacitação que proporcionem um respaldo à equipe para expor e trabalhar seus sentimentos e reações. (MS, 2001, p.31)

A SPM, na norma técnica de uniformização para centros de referência, orientou sobre a formação continuada dos profissionais, distinguindo capacitação e supervisão, sugerindo ainda um programa para curso de capacitação. Na capacitação, acentuou a abordagem dos aspectos mais formais:

A formação profissional deve estar pautada por uma metodologia dialógica, interdisciplinar, holística que incentive a mobilização. A formação continuada de natureza técnica e operacional deve incluir disciplinas específicas, tais como: legislação que assegura os direitos das mulheres, técnicas de atendimento e acolhimento, dentre outros. Os conteúdos programáticos devem estimular o aprimoramento do trabalho em equipe, mobilizando e integrando as instituições que compõem a Rede e a melhoria crescente da qualidade do atendimento/acolhimento. (SPM, 2006b, p.26)

O cuidado com o impacto emocional dos profissionais no trato com as situações de violência, na visão da SPM, caberia no espaço de supervisão, que teria o objetivo de aprimorar o trabalho assistencial e prevenir problemas de saúde e rotatividade dos profissionais:

A supervisão é um meio para profissionais aprimorarem o seu próprio trabalho. Os supervisores devem ser especialistas, treinados para fornecerem apoio individual e de grupo para uma equipe técnica. É aconselhável procurar profissionais que sejam sensiveis às questões de gênero e tenham experiência na área da violência contra a mulher. A supervisão deve ocorrer dentro de um contexto definido que relacione tanto a atitude, como as regras estabelecidas para realizar a tarefa nas melhores circunstâncias possiveis e lide com o impacto para a saúde mental e física dos(as) profissionais expostos(as) a relatos traumáticos contados por mulheres atendidas, de forma a evitar a ocorrência da síndrome do stress pós-traumático secundário, também conhecida como burn-out e a alta rotatividade de profissionais. (idem, p.27 - grifos nossos) 
Nas normas técnicas para Centros de Referência e para DEAMs, viu-se que a SPM compreende que oferta de capacitação e supervisão dos profissionais foi uma das atribuições dos Centros de Referência, como parte da articulação do trabalho em rede. Para Centros de Referencia, estabeleceu:

A formação e qualificação contínua devem ser asseguradas aos profissionais do Centro de Referência. A expertise desenvolvida pelos profissionais do Centro de Referência os habilita a promover atividades de qualificação para os demais profissionais dos serviços da Rede de Atendimento. (norma técnica de uniformização - centros de referência, SPM, 2006b, p.12, grifos nossos)

A maior prioridade deve ser o investimento na formação continuada e na valorização profissional da equipe técnica e administrativa do Centro de Referência e da Rede de Atendimento, que resulte numa crescente compreensão do fenômeno da violência, suas causas e instrumentos de superação individual e coletiva. Esta visão abrangente, motivadora e sensivel aumentará de forma significativa a atenção e os cuidados no atendimento às mulheres em situação de violência. (idem, p.26, grifos nossos)

Entre as atribuições da coordenação das DEAM, que seriam as delegadas, estavam:

Propor discussão permanente com a Rede de Atendimento, promovendo reuniões e formação /capacitação conjunta, acompanhando, dirimindo dúvidas e impasses na relação das Delegacias com os serviços da Rede de Atendimento; Participar ativamente da Rede de Atendimento, promovendo reuniões para fortalecimento das articulações entre as diversas unidades envolvidas $e$ atividades de formação/capacitação conjunta visando estabelecer um sistema de referência e contra referência para acompanhar as mulheres atendidas e os desdobramentos efetivados; Propor a realização de cursos de formação / formação continuada para os profissionais de Segurança Pública que estão lotados nas DEAM. (norma técnica de padronização - DEAMs, SPM, 2006a, p.33)

Em todos esses documentos normativos, havia orientações para a capacitação e supervisão da equipe diferentes das capacitações técnicas tradicionais, pois incluiram o acolhimento dos sentimentos dos profissionais, trabalhando o impacto 
emocional das situações de violência sobre eles. Aprender a lidar com os próprios sentimentos de indignação, frustração e impotência e com a ambigüidade das usuárias foi visto, nesta perspectiva, como elemento da tecnologia assistencial. Percebeu-se um deslocamento interessante neste ponto a respeito do trabalho do psicólogo: as dificuldades no trato com as ambigüidades e o impacto emocional, que as policiais entrevistadas na pesquisa do CNDM e a equipe do abrigo de Belo Horizonte (Alves e Coura Filho, 2001) relacionaram com a necessidade de apoio psicológico e psicoterápico - e talvez seja uma compreensão recorrente para os profissionais em geral - foram tratadas pelos formuladores das políticas públicas como parte da complexidade da assistência a situações de violência e deveriam ser trabalhadas em equipe, com discussões de casos, compartilhando as impressões e sentimentos que emergem na condução destes atendimentos. Mais do que o apoio psicológico, as orientações - do MS e da SPM - acentuaram a importância da qualificação profissional por meio de discussão sobre as desigualdades de gênero, o conhecimento da dinâmica das relações violentas, decisões conjuntas sobre decisões e direcionamento das ações assistenciais. Ou seja, segundo o MS e a SPM, o desenvolvimento da tecnologia assistencial ocorreria aproximando-se do problema e garantindo o apoio na própria equipe multiprofissional, ou com especialistas no tema da violência de gênero.

Coerente com a compreensão de que seria necessária melhor qualificação no tema para os profissionais, os documentos do Ministério da Saúde e da Secretaria de Políticas para Mulheres introduziram as orientações com a apresentação do problema da violência de gênero, o ciclo da violência e definições conceituais sobre o fenômeno. A ênfase das orientações foi na construção da tecnologia assistencial, 
atentando para o acolhimento adequado (com respeito, compreensão e sigilo, buscando fortalecer a mulher no enfrentamento dos conflitos relacionados à situação vivida), avaliação dos impactos para a saúde e autonomia da mulher, avaliação dos riscos para a mulher e seus filhos, clareza de que a intervenção tem caráter de prevenção secundária, necessidade de facilitar a inclusão social da mulher (principalmente nos abrigos), necessidade de promoção de novas formas de estabelecer relacionamentos afetivos não violentos, definição de fluxograma específico, elaboração de plano terapêutico individual e orientações sobre os direitos e encaminhamento para outras instituições, além da perspectiva da promoção de saúde e prevenção da violência. $\mathrm{O}$ trabalho multidisciplinar e articulado com outras instituições também foi bastante acentuado nestas orientações, e não se restringia aos encaminhamentos a outras instituições, contemplando os direitos, a reflexão sobre a desigualdade de gênero e a busca de apoio familiar e social como temas a serem trabalhados pela equipe como um todo. Além disto, as recomendações orientavam para uma relação dialogada com a clientela, onde a avaliação dos riscos e a tomada de decisões deveriam ser feitos pela usuária, com auxílio de informações e orientações do profissional.

Estas orientações remeteram a particularidades da atenção às mulheres em situação de violência que chamam a atenção para a necessidade de reformulações na postura e prática assistencial, desde a relação com a usuária, até a relação com os colegas e os outros serviços, além de pressupor alinhamento de políticas públicas que dêem respaldo a esta configuração. Esta necessidade de reformulação já estava posta para as outras demandas dos serviços - especialmente na Saúde, quando se falou de atenção integral - , mas pareceu mais evidente e premente quando se refere à 
violência de gênero. Viu-se ainda, nestas orientações, o delineamento de um objeto de trabalho comum à equipe, com conseqüente direcionamento para um projeto assistencial comum, configurando uma proposta de trabalho em equipe que, se efetivada, se aproximaria do que Peduzzi (1998) denomina como equipe integração.

Notou-se que somente nas normas técnicas para as DEAMs havia orientações para atendimento psicológico das profissionais, e estavam incluídas nas ações preventivas que devem ser promovidas pela Rede de Atendimento. A SPM e a SENASP explicitaram que seria necessário promover transformação de valores discriminatórios e de preconceitos contra as mulheres, com a finalidade de redução dos índices de violência, sendo que a corporação policial deveria participar, junto com a rede de atendimento, na construção de uma cultura de paz. Com relação ao atendimento psicológico, afirmaram que caberia à rede de serviços, dentre as atividades de prevenção, organizar espaços de apoio para as policiais:

Criação de espaços de atendimento psicológico para as (os) profissionais das Redes de Atendimento, especialmente para aquelas (es) que atuam nas Delegacias, dadas as características da profissão policial, expostos a constantes situações de pressão e estresse. É necessário empreender uma política de saúde que contemple, de forma qualificada, o suporte psicológico e social às (aos) servidoras (es). (SPM, 2006a, p. 42)

Nessa norma técnica, apesar de terem acentuado a importância de formação adequada às policiais para um atendimento humanizado, observou-se a percepção da necessidade de atendimento psicológico aos profissionais. Um atendimento que deveria ser garantido a todos os profissionais da rede, e principalmente para as policiais, por conta do estresse e da pressão próprios do trabalho policial. Estas orientações corroboraram a percepção das policiais identificadas na pesquisa da CNDM (Silva, 2002), já descritas no capitulo 2, que identificou entre as policiais que 
trabalham com violência contra mulheres a demanda por apoio psicológico. Na nossa compreensão, esta demanda estaria relacionada mais à necessidade de supervisão do que de atendimento psicológico, pois se configuraria como oferta de suporte para os profissionais para lidarem melhor com as situações de pressão e estresse relacionados às exigências do trabalho. É importante lembrar ainda que a garantia de acesso a atendimento psicológico, como outros atendimentos de saúde, seria de competência do Sistema Único de Saúde e suas políticas de saúde, para a população em geral, sempre que necessário.

A partir desses documentos normativos, notou-se que poderia existir espaço, demanda e orientações para o trabalho do psicólogo na capacitação e/ou supervisão dos profissionais, apesar de o trabalho não se restringir a este profissional e a principal exigência nos documentos foi ter experiência no tema. A participação dos psicólogos poderia ser de compartilhar o seu saber para que todos possam lidar melhor com os aspectos afetivos no trabalho com as situações de violência e com a clientela que traz este tipo de queixa. A necessidade de aprender a lidar com estes aspectos e de garantir um espaço institucional para isto, por meio de supervisões e capacitações, foi reconhecido e valorizado nos documentos oficiais do Ministério da Saúde e da Secretaria Especial de Políticas para Mulheres, como parte da tecnologia assistencial voltada para as situações de violência de gênero.

Desta forma, o psicólogo poderia contribuir nestas supervisões e capacitações à medida que dispõe de instrumentos técnicos para lidar com o sofrimento alheio e os afetos implicados na relação terapêutica. Instrumentos que poderiam ser compartilhados com a equipe, construindo um saber comum e que contribuiriam para aperfeiçoar o trabalho dos profissionais em geral. Mas é importante lembrar que estas 
técnicas não seriam suficientes para lidar com as ambigüidades das mulheres, os sentimentos de indignação, impotência e frustração freqüentes no atendimento a estes casos. Compartilhar as dúvidas e angústias, assim como pensar em conjunto as possíveis soluções e encaminhamentos seriam necessários ao trabalho, pois se configurariam como casos complexos e demandariam não só reflexão em grupo, como apoio da equipe e do serviço nas decisões mais difíceis. Neste sentido, os psicólogos também necessitariam de supervisão e capacitação, além do apoio e coresponsabilização na assistência, decorrentes do trabalho em equipe.

\section{B - Do atendimento às mulheres usuárias dos serviços}

Nas orientações da SPM para os centros de referência (SPM, 2006b) e abrigos (SPM, 2003) o trabalho do psicólogo estava relacionado às tarefas de promoção de auto-estima, aconselhamento, escuta e acolhimento. Atribuições que foram ao mesmo tempo preconizadas para todos os profissionais da equipe, compondo o projeto assistencial comum destas equipes.

Nas DEAMs (SPM, 2006a), a escuta e acolhimento foi definido nas normas técnicas como tarefa das policiais, sendo que o atendimento psicossocial, bem como o atendimento psicológico, deveriam ser referidos aos centros de referência e serviços de saúde da rede local.

Nos documentos da Saúde houve diferenças quanto às atribuições dos psicólogos entre o protocolo para Atenção Básica (MS, 2001) e as normas técnicas para assistência a situações de violência sexual (MS, 2005a e 2005b). Para a atenção básica, as orientações foram semelhantes às da SPM. Já nas normas técnicas, por serem voltadas para o atendimento a situações de violência sexual, incluindo aquelas 
que ocasionaram gravidez, as orientações para o atendimento psicológico foram mais específicas e voltadas às repercussões da violência sexual na saúde sexual e reprodutiva da mulher.

\section{O atendimento psicológico nas orientações para as DEAMs}

Com o objetivo de propor uma padronização dos serviços prestados pelas DEAMs, e superar os impasses e as divergências já apresentados no capitulo 2, a norma técnica definiu a função e especificidade destas unidades policiais:

Na qualidade de Delegacia Especializada da Polícia Civil, cabe as DEAMs incorporar também o desafio da adequação de sua atuação aos desafios de novas realidades sociais, no exercício de suas atribuições, quais sejam prevenir, registrar, investigar e reprimir atos ou condutas baseadas no gênero que se configurem infrações penais e que tenham sido cometidos contra mulheres em situação de violência, por meio de acolhimento com escuta ativa, realizada preferencialmente por delegadas, mas também delegados, e equipe de agentes policiais, profissionalmente qualificados e com compreensão do fenômeno da violência de gênero, nos termos da Convenção de Belém do Pará.(SPM, 2006a, p.22 - grifos nossos)

As autoridades policiais lotadas nas DEAMs devem realizar - ou determinar que se realize - todos os procedimentos policiais cabiveis para a elucidação de notícia de fato que se configure infração penal sob sua atribuição investigativa e adotar medidas protetivas, bem como encaminhar a mulher atendida para a Rede de Atendimento à Mulher em Situação de Violência.(idem, p.25)

A proposta da norma técnica pareceu definir o impasse sobre as funções das DEAMs, como apontado por Silva (2002) a respeito do trabalho estritamente policial e o extra-policial, e da lotação de assistentes sociais e psicólogos nestas delegacias. Pela norma técnica, caberia às DEAMs o trabalho policial de investigação, registro de queixas, repressão, prevenção e proteção, nos moldes de um atendimento humanizado (com escuta qualificada, sigilosa e não julgadora). Configurado desta forma, parece que as atividades "extra-policiais" (mediação de conflitos, conciliação, 
assistência psicossocial e psicológica, serviço social e assistência jurídica) caberiam aos centros de referência, aos serviços de saúde, serviços de assistência social e outros integrados na rede de atendimento.

No âmbito da Rede, há de se destacar o papel dos Centros de Referência como um espaço de acolhimento e atendimento psicossocial, que possibilita uma reflexão sobre a condição feminina e a violência de gênero, orienta e encaminha para os serviços de saúde, de assistência social, de qualificação profissional e de natureza jurídica. A consolidação desses Centros permite, também, que as Delegacias recuperem sua função policial de registrar, por meio da escuta qualificada e não julgadora, o relato da história de cada mulher, de apurar e investigar a violação de direitos e infrações penais, e possibilitar a punição dos agressores. (SPM, 2006a, p.39grifos nossos)

Diferente do projeto inicial das DEAMs (Barsted, 1994), a norma técnica propôs que as equipes destas delegacias deveriam ser compostas por policiais (delegada, investigadores, escrivãs) e pessoal de apoio administrativo e de serviços gerais. $\mathrm{O}$ trabalho multiprofissional que no início dos anos 80 era pensado no interior das DEAMs, em 2006 foi indicado que fosse composto com profissionais de outros serviços, na articulação em rede.

Além disso, quando trataram do monitoramento das ocorrências, definiram, entre outros procedimentos, que:

Quando forem localizados registros policiais anteriores, a mulher deverá obrigatoriamente ser encaminhada a um Centro de Referência ou a uma Casa Abrigo, dependendo da gravidade do caso, onde receberá a orientação adequada e atendimento psicossocial. (p.31)

Desta forma, havia uma compreensão de que nos casos onde a violência de gênero é recorrente, haveria necessidade de orientação e atendimento do tipo psicossocial, especializados no tema. Estabeleceram uma rotina no fluxo de atendimento, na qual os casos crônicos - e talvez mais complexos, em termos assistenciais - deveriam ser acolhidos e acompanhados pelos centros de referência e 
abrigos. Reconheceram, assim, que os casos mais complexos, nos quais as mulheres teriam mais dificuldades de sair da situação de violência, demandariam intervenções que ultrapassavam as competências policiais. Estas orientações são recentes, datam de 2006, e a implementação desta proposta só poderá ser avaliada futuramente. Mas de qualquer maneira, viu-se que o lugar do psicólogo, na articulação com o trabalho policial ficou mais bem definido.

\section{Os psicólogos nos serviços de saúde de atenção à violência}

A saúde tem tradição de sistematizar as orientações para a assistência na forma de normas técnicas e protocolos, principalmente aquelas que se referem ao trabalho médico. As orientações para os outros profissionais em geral vieram na esteira das orientações para médicos e foram menos detalhadas do que as orientações para a assistência biomédica.

Com relação ao atendimento psicológico nos casos de violência contra a mulher, a NT de Prevenção e Tratamento de Agravos Resultantes da Violência Sexual contra Mulheres e Adolescentes (2005a) e a proposta para a atenção básica (2001) citaram o psicólogo como um profissional importante, com diferentes tarefas assistenciais:

(...) o acompanhamento psicológico, realizado por profissionais da equipe de atenção primária ou de saúde mental, é útil para uma mudança nos padrões do relacionamento, em intervenções de longo prazo. Os profissionais devem identificar pacientes com alto risco de tornarem-se abusadores no futuro, os quais devem ser encaminhados a serviços de saúde e buscar alternativas não violentas na resolução de conflitos. (MS, 2001, p.49, grifos nossos)

... deve-se oferecer atendimento psicológico e medidas de fortalecimento da mulher, ajudando-a a enfrentar os conflitos $e$ problemas inerentes à situação vivida. (MS, 2005a, p.21) 
O atendimento psicológico deve ser iniciado o mais breve possível, de preferência desde a primeira consulta, mantido durante todo o periodo de atendimento e pelo tempo necessário. (idem, p.13)

No entanto, as delimitações sobre o trabalho específico do psicólogo e dos outros profissionais da equipe foram pouco claras nestas orientações. A todos caberia atentar para os impactos emocionais e buscar o fortalecimento das pessoas envolvidas com a situação de violência. Pode parecer óbvio para muitos profissionais que o trabalho específico do psicólogo seria a psicoterapia, mas isto não foi explicitado em nenhum destes documentos. Nos Cadernos de Atenção Básica os autores remeteram o atendimento psicológico para a equipe de saúde mental ou de atenção primária, evidenciando que esse trabalho deveria ser realizado pela rede de assistência não específica para situações de violência intrafamiliar. Esta foi uma orientação que pareceu se contrapor às outras orientações do Caderno, que acentuaram as características específicas do atendimento a pessoas nestas situações.

Houve também referência à atividade de prevenção no trabalho psicológico, na identificação de possíveis abusadores, como viu-se na proposta para atenção básica. A identificação pareceu ser colocada como tarefa para todos os profissionais, mas o acompanhamento caberia aos psicólogos da saúde mental ou da atenção primária. Porém, não constavam orientações sobre como identificar, nem como atender. É importante lembrar que este tipo de previsão, que identificaria "futuros abusadores" abre espaço para juízos morais e para intervenções orientadas por concepções pessoais a respeito dos relacionamentos conjugal e familiar adequados, podendo estigmatizar os homens e comprometer os cuidados que seriam necessários. Por isso, seria preciso aprofundar a discussão sobre estes aspectos, definindo melhor 
objetivos, formatos dos atendimentos e discutir se haveriam técnicas para a identificação dessas pessoas.

$\mathrm{Na}$ NT de 2005, apesar de ter afirmado que se devia oferecer atendimento psicológico à vitima de violência sexual e que este deveria ter início assim que a mulher dá entrada no serviço, também foi estabelecido que caberia a toda a equipe "contribuir para reestruturação emocional e social da mulher (...) em todas as fases de atendimento”. (MS, 2005a, p.13). A norma não discriminou como cada profissional poderia contribuir de formas diferentes, dentro de suas especificidades. Por não definir o que seria de todos e o que seria específico de cada um nesta "reestruturação emocional e social", notou-se o risco de sobrepor funções da equipe com as potenciais funções do psicólogo.

Na tentativa de definir melhor o trabalho, o capitulo 3 desta NT foi dedicado à atenção psicossocial, aparentemente dirigido aos psicólogos e assistentes sociais, mas não discriminando as funções entre estas duas áreas. Neste capitulo, constavam orientações semelhantes às dos Cadernos de Atenção Básica, voltadas para toda a equipe quanto a: postura de respeito à autonomia, individualidade e direitos; sigilo; articulação intersetorial de ações de assistência e encaminhamento; atenção ao contexto de violência e não somente à situação de violência sexual; atendimento à mulher e à família; avaliação de riscos de repetição e agravamento da violência. Além destas, ainda há considerações sobre o cuidado no seguimento psicológico a mulheres homossexuais, cuja violência sexual poderia agravar sentimentos de exclusão, humilhação e isolamento já existentes na vida destas mulheres. Houve sugestão de elaboração de um fluxograma de atendimento, para dar agilidade e resolutividade ao atendimento e para evitar que a mulher tenha que contar a 
experiência de violência repetidamente. Além do fluxo específico para o atendimento às situações de violência, também sugeriram a elaboração de um plano terapêutico individual, adequando a assistência às necessidades individuais. Houve ênfase na necessidade de suporte para a equipe técnica, por meio de capacitações, discussões em grupos, oficinas, atualização e auto-avaliação, para garantir a qualidade do atendimento e bem estar dos profissionais.

Em todo este capitulo da NT, não constou especificação clara para quais profissionais são direcionadas estas orientações. Em alguns momentos, foram dirigidas aos psicólogos e aos assistentes sociais. Porém, pareceu que eram orientações que caberiam para qualquer profissional da equipe do serviço.

Exigiu-se também atendimento psicossocial nos casos de gravidez decorrente do abuso sexual, como apoio à mulher na decisão de realizar ou não o aborto. Nesta NT constavam algumas orientações sobre a assistência a estes casos, mas foi na NT de Humanização ao Abortamento, também de 2005, que foram observadas instruções mais detalhadas para o atendimento psicológico. A ênfase da NT foi no atendimento humanizado, e pretendeu ser

“(...) não apenas como guia de cuidados, mas também na intenção de oferecer às mulheres, aos serviços de saúde e à sociedade novo paradigma que torne segura, sustentável e efetiva a atenção às mulheres em situação de abortamento" (MS, 2005b, p.10).

Portanto, não forma orientações específicas para situações de violência, mas para qualquer caso no qual o aborto está previsto. Cabe lembrar que o aborto no Brasil é legalizado para as situações nas quais há risco para a gestante e no caso de estupro.

Como nos outros documentos, também se preconizou atuação multidisciplinar, onde todos deveriam estar sensibilizados e capacitados para um 
acolhimento e orientação adequados na prática cotidiana. Mas foi o único onde foi encontrada a indicação sobre integração do trabalho de assistentes sociais e psicólogos no atendimento, respeitando suas especificidades, lembrando que estas áreas de conhecimento teriam enfoques diferenciados "no trato das questões emocionais, relacionais e sociais". Este é um ponto importante na organização da assistência e do trabalho em equipe multiprofissional, pois estabelece uma relação de autonomia técnica, como já comentado anteriormente. Apesar desta ressalva, não constaram maiores discriminações sobre as diferenças entre os trabalhos do psicólogo e do assistente social. Nesta NT, à saúde mental e ao serviço social caberia, então:

a) Prestar apoio emocional imediato e encaminhar, quando necessário, para o atendimento continuado em médio prazo;

b) Reforçar a importância da mulher, respeitando o estado emocional em que se encontra, adotando postura autocompreensiva, que busque a auto-estima;

c) Identificar as reações do grupo social (famílias, amigos, colegas) em que está envolvida;

d) Perguntar sobre o contexto da relação em que se deu a gravidez e as possiveis repercussões do abortamento no relacionamento com o parceiro;

e) Conversar sobre gravidez, abortamento inseguro, menstruação, saúde reprodutiva e direitos sexuais e reprodutivos. (MS, 2005b, p.20)

Especificamente sobre a atuação do psicólogo, observou-se a seguinte orientação:

Do ponto de vista da escuta e da orientação oferecida pela Psicologia, alguns aspectos podem ser aprofundados a depender da disponibilidade da mulher e das condições do serviço para este atendimento. Podem estar incluídas no roteiro de conversa questões como a maternidade e o desejo de ser ou não ser mãe, a sexualidade e o relacionamento com o parceiro. Assim como, na perspectiva da prevenção da repetição do abortamento, é importante o espaço para elaboração subjetiva da experiência, com a verbalização dos sentimentos, a compreensão dos significados do abortamento no 
contexto de vida de cada mulher e dos motivos que levaram ao surgimento de uma gravidez não planejada. (idem, p.18)

Com estas orientações, o que nas outras normas técnicas e no Caderno de Atenção Básica denominou-se de "fortalecimento" e "reestruturação emocional e social" ganhou um contorno um pouco mais nítido e havia diretrizes mais específicas para a assistência psicológica. $\mathrm{O}$ atendimento psicológico estava configurado com foco nas questões relacionadas à demanda (qual seja, a gravidez de risco ou decorrente de estupro). No entanto, é importante ressaltar que a perspectiva de "prevenção da repetição do abortamento" e a discussão sobre gravidez não planejada diz respeito à gravidez de risco e não às situações de violência sexual.

Cabem ainda algumas considerações sobre os objetivos do atendimento. Nas orientações para atenção básica, o atendimento psicológico foi previsto como intervenção de longo prazo, com o objetivo de promover mudanças nos padrões de relacionamento conjugal ou familiar. Enquanto que nos serviços voltados para violência sexual, o objetivo foi auxiliar na elaboração da situação de violência e a retomada da vida sexual.

Interessante notar que as NTs sobre violência sexual e sobre aborto previsto em lei trouxe recomendações que seriam adequadas para violência ocasional, perpetrada por estranhos, apesar de citar a violência sexual conjugal. Porém, para a violência cometida por pessoas íntimas (familiares e parceiros), casos em que as agressões são freqüentes e "crônicas", a profilaxia para DST/AIDS e a contracepção de emergência não teriam efetividade, e o acolhimento e elaboração da experiência traumática para retomada da vida sexual não caberia, porque a convivência com o agressor poderia se manter. Isso provavelmente tem relação com o fato da NT ser mais extensa e precisa para os aspectos biomédicos. Cabe lembrar que a Saúde tem 
conhecimentos e tecnologia consolidada para atuar no corpo e na dimensão biomédica. O desenvolvimento da tecnologia médica ocorre justamente pela redução do objeto (pessoa adoecida) para um objeto passível de intervenção (corpo), apartando os aspectos sociais, culturais e de relação interpessoal nos processos de adoecimento.

Desta forma, talvez não seja por acaso que a violência sexual teve mais facilidade para ser acolhida e reconhecida na saúde do que a violência doméstica e a violência sexual por parceiro íntimo. A violência sexual tem repercussões mais evidentes e imediatas para a saúde, como DSTs, gravidez indesejada e problemas no relacionamento sexual. Para os casos de abuso sexual perpetrados por desconhecidos, há possibilidades tecnológicas de intervenção mais claras e imediatas como a profilaxia, potencialmente evitando infecção de DST/ HIV e gestação indesejada. É para estes problemas que as normas técnicas (NT) focaram suas orientações. Nos casos onde o agressor seria conhecido (familiar ou parceiro), as relações sexuais forçadas seriam mais freqüentes e demandariam outros procedimentos, tanto para evitar gravidez indesejada, DSTs/HIV, como para auxiliar a mulher a sair da situação de violência. Os Cadernos para Atenção Básica teve como foco a violência intrafamiliar, com orientações para a equipe de saúde sobre a violência doméstica contra criança, idosos e mulheres, mas citaram intervenções bem mais vagas e menos delimitadas e também não discutiu a assistência às situações de violência sexual por parceiro íntimo.

Com relação às situações de violência intrafamiliar e conjugal, cabe explicitar a recomendação que constava na NT (2005a) e no Caderno de Atenção Básica a respeito do atendimento familiar e de casal. Nestes documentos, este tipo de 
atendimento foi indicado para os casos de violência por parceiro íntimo, somente quando houvesse interesse ou necessidade de preservar os vínculos parentais. Como outras orientações destes documentos, também não ficou explícito o profissional que deveria realizar este atendimento, seja na própria unidade, seja encaminhando para outro serviço. Orientações que divergiram da proposta de atendimento de casal feita por Araújo (1996), que circunscreveu o atendimento como psicoterapia e portanto, restrito a psicólogos.

No Caderno havia algumas orientações para o atendimento de casal, no capítulo direcionado ao atendimento aos homens. Foram instruções para a equipe em geral. Recomendaram, num primeiro momento, atender separadamente, para garantir a escuta de ambos sem a intimidação do agressor. Só depois seria indicado atender o casal, com o objetivo de lidarem de forma mais adequada com a situação de conflito, independentemente da intenção de separar ou não. Havia considerações sobre o uso de drogas e a ressalva de que este não deveria ser o foco do atendimento, visto que seria um sintoma e não a causa dos conflitos e da violência. Estabeleceram que o tratamento

(...) deverá abordar, num segundo momento, questões emocionais do individuo, desenvolvendo sua responsabilidade pelas mudanças em sua vida e a conseqüente repercussão desse fato nas pessoas que conviveram com ele. (MS, 2001, p.67)

A compreensão que norteou as orientações destes documentos foi de que a violência familiar e/ou conjugal seria uma forma de resolução de conflitos e os profissionais deveriam basear a assistência no fortalecimento e busca de novas alternativas de resolução - pacíficas e apoiadas no diálogo. Conforme as instruções do Caderno de Atenção Básica, o "fortalecimento da auto-estima” também deveria ser promovido junto aos homens, como uma das medidas de prevenção à violência 
familiar ou conjugal, através de grupos de discussão para homens e/ou atendimento individual. No entanto, o atendimento de casais talvez seja uma situação assistencial nova e complexa para a maioria dos profissionais. É importante lembrar que o atendimento conjunto, seja de casal, seja de família, exige muita clareza do profissional de sua função e dos objetivos de sua intervenção, para que não se envolver na dinâmica interpessoal já estabelecida pelo casal ou família de forma a prejudicar a sua função de ajuda. De qualquer maneira, o protocolo não definiu se o atendimento de casal seria configurado necessariamente como psicoterapia ou não, as diferenças de objetivos que cada um teria, e se poderia ser realizado por outros profissionais que não psicólogos. Em sendo realizado por outros profissionais, também não orientaram qual seria a formação adequada. Apesar disto, as orientações existentes poderiam ser importantes como diretrizes assistenciais, lembrando aos profissionais a dimensão relacional da violência e que a intervenção deveria contemplar outros membros da família, incluindo o agressor, para auxiliar na promoção de transformações no padrão de relação e de diálogo na família.

A compreensão de que a violência intrafamiliar/ conjugal seria uma forma de resolução de conflitos, que demanda ações de fortalecimento e promoção do dialogo entre os envolvidos na situação de violência, é uma novidade para a Saúde, que costuma dar ênfase aos aspectos biomédicos. Com este recorte de objeto e de intervenções, ofereceu-se aos profissionais alternativas à medicalização da violência. No entanto, ainda seria importante delimitar melhor a assistência psicológica especializada em violência, fazer a discussão dos objetivos específicos e dos procedimentos, diferenciando o trabalho do psicólogo do trabalho dos outros profissionais. Delimitação necessária para a construção de um projeto assistencial da 
equipe, com melhor integração do trabalho específico de cada profissional. Para uma melhor integração entre os vários níveis de atenção em saúde, articulando melhor a relação de referência e contra-referência, também seria interessante definir e diferenciar o papel do psicólogo na atenção básica, na atenção especializada para violência sexual e para os casos de gravidez decorrente do abuso sexual, incluindo os casos de violência nas relações de intimidade.

Nesses documentos normativos viu-se que o termo psicossocial foi entendido de forma difusa, por vezes identificado com o trabalho do psicólogo e do assistente social, sem distinções claras sobre suas especificidades, outras vezes como uma postura assistencial que caberia a todos os profissionais da equipe técnica. Aparentemente, na saúde, tudo aquilo que se afastou do referencial biomédico teve a tendência de ser chamado de psicossocial. Esta delimitação difusa provavelmente refletiu o pouco conhecimento dos profissionais em geral sobre o trabalho do psicólogo e do assistente social.

\section{O trabalho psicossocial - Centros de Referência e abrigos}

Os centros de referência e os abrigos para mulheres em situação de violência foram os serviços identificados com a assistência psicossocial, e tiveram como principais atividades assistenciais os atendimentos social e psicológico. As normas e protocolos da SPM orientavam a organização do trabalho nestes tipos de serviços, a partir do nível federal. Como houve diferenças grandes entre estes tipos de serviços, serão apresentadas separadamente as propostas sugeridas pela SPM. 


\section{Centros de referência}

A proposta do Programa de Prevenção, Assistência e Combate à Violência contra a Mulher, da Secretaria de Políticas para Mulheres trouxe comentários sobre o lugar dos centros de referência na rede de assistência e dispôs sobre o funcionamento dos abrigos. Na avaliação dos formuladores deste programa, seria necessário superar o isolamento e onipotência que teria caracterizado a experiência dos serviços na década de 90 e as dificuldades no atendimento. Para tanto, propuseram a disseminação dos Centros de Referência e a articulação da Rede de Cidadania, pretendendo garantir o acesso aos serviços e a qualidade da assistência, e assegurando condições para a mulher conquistar sua cidadania.

"As políticas de proteção e segurança são essenciais para o enfrentamento à violência, mas é preciso avançar tanto em políticas de prevenção como na ampliação de políticas que articuladamente trabalhem para uma reversão da dependência financeira, elevação da auto-estima das mulheres, fortalecimento da capacidade de representação e participação na sociedade, enfim, criem condições favoráveis à autonomia pessoal e coletiva. Também as repercussões à saúde que são causadas pela violência doméstica tem que ser assumidas e acolhidas em programas de assistência a vitimas $e$ agressores". (SPM, 2003, p.48)

Orientaram a articulação e ações integradas e descentralizadas (respeitando as características de cada região) entre serviços da área jurídica e de proteção, na área social, área de saúde, área de segurança e serviços e organizações ligados a ações de educação e cidadania. Nesta proposta de rede, as portas de entrada seriam: centros de referência, serviços de apoio jurídico, serviços policiais (delegacias da mulher, outras delegacias, policia militar), postos de saúde e serviços de emergência, escolas e órgãos comunitários, ouvidorias, organizações não governamentais e conselhos. Como centros de referência também estariam a Defensoria Pública, casas-abrigo e Instituto Médico Legal. 
O Centro de Referência, como o próprio nome diz, é o local de referência e orientação, responsável pelos encaminhamentos da Rede. Propulsor do processo de resgate da mulher como ser social, isto porque tem o papel de dar atendimento e acompanhamento psicológico e social à mulher em situação de violência, resgatando e fortalecendo sua auto-estima e possibilitando que esta se torne sujeito de seus próprios direitos. (SPM, 2003, p.51)

Os Centros de Referência de Atendimento à Mulher são equipamentos da política de prevenção e enfrentamento à violência contra a mulher que: funcionam como porta de entrada especializada para atender a mulher em situação de risco na rede de atendimento. Estes serviços elaboram diagnósticos preliminares da situação concreta de violência, encaminham à Rede de Serviços, acompanham $o$ atendimento e oferecem orientações gerais, bem como atendimento psicológico, social e jurídico à mulher vítima de violência sexual, física e psicológica, esporádica ou de repetição, ocorrida no contexto de nenhuma relação (cometida por desconhecidos), de relações de afeto e confiança elou de trabalho. (SPM, 2006b, p.28)

Devem exercer o papel de articuladores dos serviços organismos governamentais e não-governamentais que integram a rede de atendimento às mulheres em situação de vulnerabilidade social, em função da violência de gênero. (idem, p.11)

Na compreensão da SPM, os centros de referência seriam ao mesmo tempo porta de entrada e referência para os serviços da rede, especializados ou não. Pode-se pensar que numa rede de serviços, que pressupõe relações horizontais e não hierárquicas entre os serviços de vocações assistenciais diferentes, não teria sentido falar em porta de entrada, já que muitos deles poderiam receber demanda espontânea. Nessa norma técnica, referiram-se a esses centros como locais de referência para encaminhamento, para atenção especializada para as mulheres em situação de violência. Mas pelas necessidades diversas de assistência, esses centros costumam reencaminhar para outros serviços. Configuram-se assim, como serviços centrais na rede, recebendo e redistribuindo a clientela pelos serviços da rede específica e da rede geral (D’Oliveira e Schraiber, 2006). 
O termo referência foi utilizado de forma diferente nos documentos de $2003 \mathrm{e}$ de 2006. No primeiro, designou tanto os serviços específicos para mulheres em situação de violência que ofereceriam atendimentos psicológico, social e jurídico, como também as Defensorias, abrigos e IML, sugerindo que qualquer serviço especializado seria referência para os outros serviços, não especializados. Notou-se indistinção no uso do termo, como também da rede específica e da rede geral. Já na norma técnica, de 2006, a SPM se referiu somente aos serviços com ênfase na assistência psicossocial e que também teriam a função de formação dos profissionais da rede e de articulação entre os serviços da rede específica.

Pela norma técnica de uniformização para centros de referência (SPM, 2006b), a função desses serviços deveria ser efetivada através das seguintes atividades: aconselhamento em momentos de crise, atendimento psicossocial, aconselhamento e acompanhamento jurídico, atividades de prevenção, qualificação de profissionais, articulação da rede de atendimento local, levantamento de dados locais sobre violência contra as mulheres.

$O$ atendimento psicossocial tem o objetivo de promover o resgate da auto-estima da mulher em situação de violência e sua autonomia, auxiliar a mulher a buscar e implantar mecanismos de proteção elou auxiliar a mulher superar o impacto da violencia sofrida. (SPM, 2006b, p.11).

Sugeriram que a equipe fosse composta por 1 coordenador(a); 2 secretários(as); 2 assistentes sociais; 2 psicólogos(as); 1 advogado(a); 2 educadores(as); 1 ajudante-geral; 1 segurança.

Propuseram ainda um fluxo de atendimento, organizado em 4 fases: acolhimento e informações gerais, orientação à mulher em situação de violência diagnóstico inicial e encaminhamento, diagnóstico aprofundado e atendimento 
(atendimento social, atendimento psicológico, arte-terapia, atendimento jurídico), e monitoramento e encerramento do atendimento.

Especificaram a participação de psicólogos na fase de diagnóstico inicial e no atendimento psicológico.

O diagnóstico inicial deveria ser realizado em conjunto com uma assistente social e teria os objetivos de: estabelecer relação de confiança, informar sobre seus direitos, avaliar riscos e necessidades específicas, elaborar plano de segurança, orientar sobre os atendimentos e elaborar em conjunto com a mulher um plano pessoal de atendimento e encaminhamento.

$\mathrm{O}$ atendimento psicológico teria o objetivo de:

(...) promover o resgate da auto-estima da mulher e a resilienica da mulher atendida, de forma a tratar possíveis sintomas de depressão e ansiedade crônica; promover paradigmas que possibilitem à mulher em situação de violência internalizar o conceito de que a violência é inaceitável e insustentável em qualquer tipo de relacionamento, por mais que possa ser freqüente no padrão do tecido social em que ela está inserida; facilitar à mulher atendida a aquisição de técnicas de contra-controle que lhe forneça instrumentos para assumir o controle da situação, saindo do papel de vítima passiva da violência doméstica e no trabalho, e de técnicas e estratégias de proteção e segurança pessoal.

Técnicas de relaxamento e controle do estresse, de resolução de conflitos e de assertividade devem integrar o atendimento psicológico.

É importante ressaltar, no entanto, que o atendimento não deve promover sessões de mediação entre a mulher atendida e o(a) agressor(a) em situações de violência doméstica. A mediação familiar é inadequada na situação de violência doméstica, uma vez que a mulher agredida e o agressor estão em papéis desiguais no que se refere ao exercício de poder pessoal.

(SPM, 2006b, p.37).

Já a arte terapia seria um complemento do atendimento psicológico e consistiria em: 
(...) sessões de atendimento individuais ou em grupo realizadas por um(a) arte-terapeuta, com o objetivo de resgatar o potencial criativo da mulher em situação de violência, ativando núcleos saudáveis de sua psique e estimulando movimentos de autonomia $e$ transformação.(idem, p.38)

Ressaltaram que a arte-terapia seria atividade específica de arte-terapeutas, diferem de atividades educativas ou artísticas e que seria preciso formação própria, não sendo qualquer profissional - seja ele psicólogo, educador ou artista - que dominaria a técnica.

Semelhante ao encontrado na revisão da literatura (Alves e Coura Filho, 2001; Araújo, 1996), a SPM entendeu o trabalho do psicólogo como parte do trabalho psicossocial de fortalecimento das mulheres pelo "resgate da auto-estima", deslocamento do lugar de vítima e promoção de autonomia. A ênfase foi no “empoderamento" e na segurança das mulheres, com a promoção de uma internalização de que a violência seria inaceitável em qualquer situação ou relação.

Chamou a atenção que neste documento não foi citada a proposta de promoção de diálogo e mudança nos padrões de relacionamento familiar e/ou conjugal, comuns nas propostas levantadas na revisão bibliográfica e presente nos documentos do Ministério da Saúde. Nesta norma técnica também acentuaram que a proposta de mediação entre o casal não seria cabível nestas situações, contrapondo com o atendimento de casal proposto por Araújo (1996), com a mediação jurídica como o apresentado por Muszkat (2003), bem como das orientações do MS. Estas diferenças refletiram divergências de compreensão do fenômeno e tensões políticas no enfrentamento da violência de gênero e que provavelmente estariam presentes na realidade dos serviços. No interior do movimento de mulheres perceberam-se críticas às abordagens que concebem a violência como um padrão de resolução de conflito na 
família, incluindo a mediação (SPM, 2006b). A crítica pareceu focar na despolitização do fenômeno, ou seja, discordaram destas abordagens por desconsiderarem - na prática - a desigualdade de gênero e a histórica opressão masculina sobre as mulheres como elementos que estariam na gênese da violência contra as mulheres.

Chamou a atenção também a tarefa dirigida ao psicólogo de promover a internalização de que a violência seria inaceitável. Esta foi uma orientação que lembrou a proposta de conscientização das mulheres pelos SOS Mulher, nos anos 80 e sugeriu, na nossa compreensão, uma prática que não levaria em consideração a compreensão das usuárias sobre a própria agressão sofrida, incutindo valores. Desta forma, desconsideraria os aspectos éticos da relação de ajuda, descaracterizando-se como uma técnica moral dependente e correndo o risco de não acolher efetivamente o sofrimento destas mulheres.

Observou-se que houve diferenças, pelo menos entre MS e SPM, de compreensão do objeto de intervenção, que resultaria em formas de trabalho potencialmente divergentes. Descreveram tecnologias de trabalho assistencial diferentes, que provavelmente seriam reflexos da realidade dos serviços, e que poderiam interferir na articulação e diálogo entre os serviços (da rede específica e da rede geral).

Voltando ao trabalho dos profissionais, nessa norma técnica distinguiram bem o trabalho do psicólogo e do assistente social, orientando ainda que o atendimento inicial deveria ser realizado em conjunto. $\mathrm{O}$ atendimento próprio do serviço social teria o objetivo de:

(...) fornecer orientações e promover a inserção da mulher atendida e de seus dependentes em programas de transferência de recursos, aos 
quais ela tenha direito, tais como: cestas básicas, fotos para documentos, fraldas geriátricas, vale-transporte, dentre outros; e nos demais serviços que se fizerem necessários. (SPM, 2006b, p.36)

Ressaltaram em diversos momentos a importância do trabalho multiprofissional articulado, cooperativo e baseado no diálogo para uma assistência integral e efetiva. A distinção clara dos papéis e funções de cada profissional foi considerada fundamental para o bom funcionamento da equipe e para a eficácia da assistência.

A fim de maior eficiência e de se evitar problemas na equipe, atribuições, funções, responsabilidades e grau de autonomia dos(as) profissionais, bem como procedimentos de trabalho devem ser estabelecidos e comunicados o mais claramente e brevemente possivel, a fim de se evitar problemas na gestão do pessoal, os quais, caso surgirem, devem ser detectados com prontidão e resolvidos eficazmente. (SPM, 2006b, p.22)

Em muitas das atividades propostas, não discriminaram os profissionais que devem desenvolvê-las, sugerindo serem atividades que não seriam próprias de nenhum profissional e que essa definição deveria ser realizada pela equipe.

Desta forma, o trabalho psicossocial aparentemente foi identificado com o atendimento do centro de referência, sendo que a assistência própria do psicólogo consistiria em promover o fortalecimento da auto-estima e autonomia, nos aspectos subjetivos e da relação familiar/ conjugal. Enquanto que a assistente social seria responsável pelo fortalecimento das mulheres através da ampliação de seus recursos no uso dos benefícios sociais e serviços aos quais teriam direito.

\section{Abrigos}

O objetivo principal das casas abrigo para mulheres em situação de violência foi descrito como de proteger as mulheres e seus filhos, como já foi apresentado, 
"favorecendo o exercício de sua condição cidadã e de seu valor de pessoa sabedora de que nenhuma vida humana pode ser violentada" (SPM, 2003, p.56). Como objetivos específicos, o protocolo elaborado pela SPM estabeleceu:

- Promover atendimento integral e interdisciplinar às mulheres e seus filhos de menor idade, em especial nas áreas psicológica, social e jurídica.

- Promover condições objetivas de inserção social da mulher, conjugando as ações da casa-abrigo a programas de saúde, emprego e renda, moradia, creches, profissionalização, entre outros.

- Prover suporte informativo e acesso a serviços, instruindo as mulheres para reconhecerem seus direitos como cidadãs e os meios para efetivá-los.

- Proporcionar ambiente e atividades propícios para que as mulheres possam exercitar sua autonomia.

- Proporcionar ambiente e atividades propícios para recuperar sua auto-estima.

- Prover meios para o fortalecimento do vínculo mãe/filhos, favorecendo modos de convivência não-violentos.

- Promover o resgate dos vínculos entre pai e filhos, fortalecendo os aspectos saudáveis da relação. (SPM, 2003, p.57)

A intenção descrita foi de buscar a reestruturação material, afetiva e de fortalecimento de cidadania, questionando os modelos de gênero e tentando promover "mudanças nas construções sociais de identidades e subjetividades". Compreenderam que a violência faria parte de um padrão de interação conjugal, atrelado aos papéis de gênero que cada um adere, e por isto, deveriam ser promovidos questionamentos do "lugar, das interações e códigos e das expectativas que reproduzem a dependência emocional”.

Como estratégias de ação, estabeleceram a interdisciplinariedade, constituição de redes locais (com serviços especializados no atendimento a situações de violência e serviços de saúde, moradia, assessoria jurídica, emprego, polícia, serviços de apoio social), capacitação da equipe (educação continuada e supervisão, na perspectiva de gênero), abordagem crítica em questões de gênero, abordagem de grupo (oficinas 
onde as usuárias possam trabalhar coletivamente as situações de violência vividas e a auto-estima) e autogestão. E autogestão, foi traduzida na participação das usuárias nas decisões de organização da casa e nos temas de grupo que seriam objeto de debate e reflexão. Com isto, pretendia-se promover a autonomia, responsabilidade e deslocamento da condição de vítima e do lugar passivo que muitas delas se encontrariam ao chegar ao abrigo, recolocando-as como sujeitos de suas ações. Além disto, buscava-se "despertar a solidariedade e humanização do espaço”.

Estabeleceram um padrão mínimo para implantação, dispondo sobre os recursos materiais, espaço adequado e equipe. A equipe mínima exigida seria composta por psicóloga (o) e assistente social como equipe permanente. Orientaram também ter uma equipe de apoio técnico (nutricionista, pedagoga (o), enfermeira (o), advogada (o), que podem ser de outras instituições, prestando serviços às usuárias e/ou profissionais da casa-abrigo); e equipe operacional (agente administrativo, cozinheira (o), auxiliar de conservação e limpeza, vigilante, motorista).

Este protocolo refletiu os avanços conquistados na prática dos serviços, observando que não bastaria proteger as mulheres da situação de risco, mas também seria preciso atuar sobre o ciclo da violência e dar sustentação para a mulher estabelecer novas formas de relacionamento e de gestão de sua vida.

Entenderam estas intervenções como pertinentes ao trabalho do psicólogo e do assistente social, pois estabeleceram estes dois como os profissionais nucleares e permanentes de todos os abrigos. Profissionais que, juntos, deveriam responder pelo atendimento à "saúde física, mental e promoção de cidadania", às mulheres e seus filhos, além de coordenação da casa, priorizando a segurança dos abrigados e a reestruturação da vida de forma autônoma. Apesar de também (como na saúde) não 
definirem parâmetros para o trabalho específico dos psicólogos nem dos assistentes sociais, delinearam muito claramente o objetivo do serviço, objeto de trabalho e alguns parâmetros para a assistência.

Uma das grandes preocupações dos abrigos seria de atuar sobre a condição de vitimização das mulheres que atendem, acentuada pela situação de risco e por ser um local onde elas estariam sob tutela. A intervenção proposta para transformar essa condição foi a promoção da autonomia e superação da dependência econômica e emocional, com uso das estratégias de auto-gestão, do acompanhamento na inserção no mundo do trabalho e na procura por moradia, além da reflexão sobre gênero nas relações conjugais e familiares.

A estratégia de autogestão proposta neste protocolo seria justamente para intervir na condição de vitimização e promover a autonomia. Ao mesmo tempo, afirmaram que

A vitimização reduz a capacidade da mulher de expressar seu desejo. O deslocamento do lugar da queixa para o lugar de sujeito desejante passa pela quebra da equação fechada "vitima x algoz". Esta é uma intervenção que pode vir a dar-se fora dos limites do programa, inclusive através de encaminhamentos a serviços adequados, na área de saúde, e que compreendam suporte psicológico à mulher, seus filhos e demais envolvidos no problema. (SPM, 2003, p.59)

Com isto, apontaram que poderia ser necessário o aprofundamento das questões subjetivas e afetivas na condição de vitimização e dependência, e que seria uma intervenção referente ao atendimento psicológico. Mas também indicaram que a assistência oferecida pelo abrigo não precisaria incluir necessariamente o trabalho de psicoterapia, que poderia ser realizado em unidade de saúde da rede geral. Desta forma, deixou claro que a função do psicólogo no abrigo não seria como clínico, na concepção tradicional e que seria possível compor com a rede básica de saúde. 
À parte os temas referentes ao abrigamento, outras propostas de intervenção nos outros serviços foram muito parecidas. Da literatura levantada e dos documentos normativos estudados, viu-se que a atenção psicossocial, tanto nos centros de referência como nos abrigos, configurou-se como acolhimento ao sofrimento das mulheres, para elaboração e ressignificação de suas experiências, superação da vitimização, fortalecimento de seus potenciais de resistência e enfrentamento dos conflitos e crises no relacionamento familiar e conjugal, com elaboração de outras possibilidades de encaminhamento da vida (novos projetos pessoais, perspectivas e formas de relacionamento interpessoal), visando promover assim a autonomia destas mulheres e a retomada da condição de sujeitos. Intervenção que poderia ser realizada tanto como atendimento individual ou em grupo, sendo que o grupo foi um recurso visto como bom para as mulheres compartilharem as experiências, vivenciarem relações de confiança e identificação, trocarem informações e buscarem soluções coletivamente. Observou-se, ainda, que este foi um trabalho que não se restringiu ao atendimento psicoterápico, nem aos psicólogos. $\mathrm{O}$ atendimento próprio do psicólogo, aparentemente, foi identificado mais frequentemente com o trabalho com a subjetividade e os padrões de relacionamento, no sentido da promoção da cidadania e da condição de sujeito.

$$
\begin{aligned}
& \qquad * * * \\
& \text { Observou-se, a partir dos documentos estudados, que o atendimento } \\
& \text { psicológico muitas vezes se confundiu com o trabalho do assistente social e que } \\
& \text { houve certo consenso do que deveriam ser os objetivos gerais dos atendimentos, os }
\end{aligned}
$$


temas a serem abordados e algumas estratégias de intervenção na assistência a situações de violência contra mulheres, com especificidades de atuação conforme a vocação assistencial dos serviços em que estavam inseridos. Porém, foram orientações gerais, com difusas definições do trabalho específico do psicólogo, que basicamente deveria realizar escuta qualificada e acolhimento, atuando no fortalecimento, na promoção da auto-estima, na superação da situação de violência e na promoção de autonomia das mulheres em situação de violência, objetivos que também foram colocados para toda a equipe multiprofissional. As orientações do MS para o atendimento psicológico a situações de violência sexual e abortamento previsto em lei foram mais restritas, com foco na saúde sexual e reprodutiva das mulheres. $\mathrm{Na}$ atenção básica, os psicólogos teriam a tarefa principal de promover mudanças nos padrões de relacionamento familiar e/ou conjugal, no sentido de desenvolver novas formas de resolução de conflito, não violentas e baseadas no diálogo. Para os abrigos a SPM acentuou a promoção de autonomia e superação da vitimização, em trabalho conjunto de toda a equipe. Nos centros de referência, segundo a SPM, os psicólogos deveriam ter foco no fortalecimento da auto-estima e o enfrentamento das agressões.

Cabe aqui algumas considerações a respeito da auto-estima e fortalecimento das mulheres, termos tão amplamente utilizados nos documentos normativos, e que também constaram dos artigos levantados. Fortalecimento das mulheres, na perspectiva feminista, refere-se a um processo mais amplo do que o "resgate" ou "fortalecimento" da auto-estima, que se restringe à valorização de si, na dimensão individual. O termo empowerment, na concepção feminista, remete a mudanças sociais e culturais, lembrando que as relações interpessoais em todos os níveis sociais 
são relações de poder desiguais de gênero. Empowerment corresponderia ao fortalecimento das mulheres, no sentido da redistribuição de poder em favor delas, sendo necessárias mudanças na ideologia patriarcal, nas estruturas das instituições sociais (família, classe, religião, processos educacionais e suas instituições, mídia, serviços e práticas de saúde, leis e códigos civis, instituições governamentais) que reforçariam e perpetuariam a discriminação de gênero e iniqüidades sociais. (Batliwala, 1994, p.130). Observando as orientações dos documentos estudados, viuse que o termo fortalecimento foi, em geral, reduzido à dimensão individual, assemelhando-se, e algumas vezes se confundindo, com o "fortalecimento da autoestima". Desta maneira, novamente, o problema da violência de gênero pareceu tornar-se individualizado e psicologizado, com compreensão reduzida do trabalho possível do psicólogo na emancipação destas mulheres e no enfrentamento à violência vivida.

O trabalho em rede foi ressaltado em todos os documentos, especialmente aqueles elaborados pela SPM. Nos documentos de 2006 (normas técnicas para centros de referência e para DEAMs), o lugar do psicólogo aparentemente ficou melhor definido na rede de assistência do que nos outros documentos. Segundo estas normas técnicas da SPM, estes profissionais não deveriam mais compor a equipe das DEAMs, tendo seu lugar nos centros de referência, abrigos e serviços de saúde. Com relação aos serviços de saúde, seria necessário discutir as competências do psicólogo especializado nas situações de violência e do psicólogo não especializado, presente nos serviços de saúde da rede geral. Nas orientações para abrigos e nos Cadernos de Atenção Básica, o atendimento psicológico foi visto como um trabalho que contribuiria para a assistência a estas situações. Cabe discutir melhor se deveria ser 
um atendimento especializado ou não, e se seria o caso de levar a capacitação a todos os profissionais da rede de saúde geral.

Ainda seria importante delinear melhor os objetivos e intervenções do atendimento psicológico, pois as divergências e indefinições poderiam trazer prejuízos ao diálogo entre os profissionais e à articulação de um projeto assistencial integrado e comum a toda a equipe técnica e à rede. Lembrando das características de ecletismo e diversidade das abordagens e práticas da psicologia, talvez não tenha sido por acaso que houve uma delimitação difusa do que seria específico do psicólogo no atendimento às situações de violência. Independentemente de refletirmos se caberia ou não definir melhor o trabalho do psicólogo, viu-se que o próprio campo da Psicologia como disciplina e como profissão pode ter contribuido para este quadro. 


\section{Vocações assistenciais}

Os serviços estudados na pesquisa sobre redes eram serviços específicos, criados para atender situações de violência contra a mulher ou contra meninas. Alguns tinham foco na violência intrafamiliar contra crianças e adolescentes, a maioria direcionava suas ações para situações de violência doméstica contra mulheres adultas, e outros - especialmente os serviços de saúde - para a violência sexual (ocasional e por estranhos, ou cometida no ambiente doméstico). Estes serviços foram categorizados, naquela pesquisa, segundo vocação assistencial, como já apresentado no capítulo 3, e divididos em policial, jurídico, saúde, abrigo, psicossocial e orientações básicas.

Cabe ressaltar que vocação assistencial difere da noção de vinculação institucional ou mesmo de setores assistenciais. Assim, por exemplo, os serviços de orientação básica de São Paulo, poderiam ser governamentais, vinculados à Secretaria da Saúde ou ONGs, todos oferecendo assistência quanto a orientações gerais para o enfrentamento da situação de violência. Da mesma maneira, na categoria jurídico, foram encontrados serviços governamentais, ONGs (unidades da OAB), ligados a órgãos da Justiça e centros de referência para situações de violência cujo principal serviço oferecido foi a assistência jurídica.

Para o atual estudo, foi utilizada esta mesma categorização, por entender que a vocação assistencial tem grande influência nas formas de organização da 
assistência e inserção dos seus técnicos, no caso, o psicólogo, da perspectiva do processo de trabalho. Foram agregadas ainda a vinculação institucional, ou seja, se era serviços governamentais ou ONGs, pois esta característica influenciaria na organização do fluxo assistencial e proposta do serviço.

Quando se tratou dos centros de referência, falou-se de serviços específicos e exclusivos para o tema, que procuravam oferecer assistência ou orientação nas áreas social, psicológica e jurídica e em geral se apoiavam no trabalho psicossocial. Aqueles que tinham ênfase na assistência à saúde, ou jurídica, ou policial, foram classificados nas respectivas categorias.

\section{I - Caracterizando os serviços por vocação assistencial}

A categoria de serviços policiais foi composta em sua grande maioria por DEAMs, cujo objetivo era apurar e investigar crimes cometidos contra às mulheres. Nas três regiões metropolitanas (Recife, Porto Alegre e São Paulo) outros serviços policiais, como o Batalhão da Policia Militar, delegacias comuns e delegacia do idoso, foram incluídos no estudo por realizarem ações especificas no enfrentamento da violência contra a mulher. Estes serviços desenvolviam principalmente atividades de registro de queixas, investigação e cumprimento de decisões judiciais. Nas três regiões estudadas, alguns deles afirmaram realizar outras ações, como por exemplo: atendimento psicológico, atendimento social, mediação para o casal, plantão das advogadas, brinquedoteca, reunião dos Alcoólicos Anônimos, grupo de oração, palestras nas comunidades (sobre violência contra a mulher, saúde da mulher, trabalho de desmistificação da violência doméstica, conscientização dos riscos das drogas). Em São Paulo, somente um serviço não era DEAM, a delegacia do idoso. 
Dentre os 22 serviços policiais paulistas, 9 serviços tinham psicólogos na equipe, todos eram DEAMs, 8 se localizavam na capital e 1 em município da Grande São Paulo.

Como serviços jurídicos, foram classificados aqueles que procuravam garantir o acesso à justiça através de advogados. As atividades principais eram de ajuizamento de ações e acompanhamento de processos jurídicos. Tratavam de questões de direito de família (ações de alimentos, pátrio poder, guarda das crianças, casos cíveis ou de pensão alimentícia, investigação de paternidade, divórcio litigioso e consensual e outros) e de direito criminal (nos casos de ameaças, calúnia, difamação, injúrias, lesões corporais, estupros e homicídios). Muitos destes serviços ofereciam também orientação jurídica, atendimento social e em alguns, mediação judicial e extrajudicial. Pela importância desta assistência na rede intersetorial de serviços e no enfrentamento à violência doméstica, grande parte deste tipo de serviço foi referida pelos outros tipos de serviço e foi incluída na pesquisa sobre redes, mesmo não reconhecendo a realização de ações específicas para esta clientela e nem sempre reconhecendo a violência como demanda importante e diferenciada nas solicitações de orientação ou ações jurídicas. Eram serviços governamentais, não governamentais (escritórios da $\mathrm{OAB}$ e ONG's feministas) ou vinculados à universidades (públicas ou privadas). Entre os que reconheciam as demandas relacionadas à violência contra a mulher estavam aqueles criados para atender esta clientela, quais sejam: as ONG's com proximidade do movimento feminista e alguns serviços governamentais.

Dos 39 serviços jurídicos de São Paulo, 7 deles tinham psicólogos na equipe, 2 eram escritórios-escola vinculados à Faculdades de Direito, 3 eram ONGs (2 
centros de referência e 1 escritório da $\mathrm{OAB}$ ) e 2 eram governamentais. Somente dois deles não estavam localizados na capital.

Os serviços jurídicos que desenvolviam apenas orientação jurídica, mas não ajuízam ações foram categorizados como serviços de orientações básicas.

Os serviços classificados como orientação básica foram aqueles que desenvolviam atividades de orientação às mulheres, mas não ofereciam atividades de assistência especializada de longo prazo. Ofereciam, assim, orientações básicas sobre direitos, sobre a rede de serviços, baseando o trabalho na escuta e acolhimento da história para elaboração de projetos e estratégias para o enfrentamento da situação de violência vivida. Eram ONG's ou programas inseridos em serviços públicos relacionados à saúde ou ao jurídico. No caso dos 9 serviços paulistas a maioria prestava assistência à saúde e somente dois eram centrados na orientação jurídica.

Desses 9 serviços paulistas de orientação básica, 5 tinham psicólogos na equipe, todos estes eram voltados para assistência à saúde e estavam localizados na capital: 2 eram ONGs e tinham como foco o trabalho na saúde da mulher; os outros 3 serviços eram unidades básicas de saúde.

Os serviços definidos como de saúde foram aqueles que centravam suas ações na assistência à saúde da mulher e possuíam médicos na equipe técnica. Em geral, organizavam a atenção com foco na violência sexual, realizando ações de profilaxia e tratamento de doenças sexualmente transmissíveis, inclusive HIV/AIDS e contracepção de emergência. Parte deles (6 serviços) realizava aborto previsto em lei. Alguns poucos serviços ainda desenvolviam outras atividades, complementares à assistência à saúde, como: assistência jurídica; atendimento psiquiátrico; grupo de "ressocialização" com relação ao trabalho, afetos, sexualidade; medicina chinesa; 
grupo de artesanato; articulação da rede de serviços para violência e participação em grupo regional de violência sexual.

Todos os 14 serviços paulistas eram serviços governamentais vinculados a órgãos da Saúde (municipal, estadual ou federal), alguns deles universitários, e na sua maioria configuraram-se como programas inseridos em instituição de saúde (hospitais, ambulatórios e unidades especializadas no atendimento a DST/ HIVAIDS) e contavam com equipe específica, mas não exclusiva - ou seja, os profissionais prestavam assistência aos outros usuários do serviço como um todo.

Destes 14 serviços paulistas, 13 contavam com psicólogos na equipe. Dois deles eram serviços vinculados a alguma universidade. Foram incluídos neste grupo os 6 hospitais que realizavam também aborto previsto em lei.

Os serviços classificados como psicossociais foram aqueles que tinham entre suas principais atividades atendimento social e/ou psicológico, com o objetivo de oferecer apoio, fortalecimento das mulheres e ampliação dos recursos pessoais e sociais/ institucionais para o enfrentamento das situações de violência. As atividades desenvolvidas para a clientela eram diversas, e foram agrupadas por tipo:

- terapêuticas, de acolhimento ou apoio psicológico (atendimento clínico psicológico, grupos de auto-ajuda, oficinas terapêuticas, terapia comunitária, mesmo que não realizada por psicólogos; o atendimento psiquiátrico);

- atendimento social (encaminhamentos a outras instituições, escuta e orientação sobre benefícios legais, acompanhamento social);

- atividades de inclusão social (alfabetização, cursos ou oficinas profissionalizantes/ de geração de renda);

- atividades de orientação, educativas e/ou de prevenção, em diversas áreas (orientação jurídica, oficinas de direitos, sobre saúde, sobre sexualidade, sobre gênero, sobre violência), com seus usuários e/ou fora da instituição, com a comunidade;

- orientação ou assistência jurídica.

Alguns serviços ainda realizavam outras atividades como atendimento médico, perícia, atividades comunitárias de confraternização; atividades de 
mobilização política, em geral feminista; atividades de supervisão, capacitação técnica e/ou assessoria no tema para outros profissionais ou instituições.

Eram ONG's ou serviços públicos vinculados a secretarias diversas, como Coordenadoria da Mulher, Secretaria da Saúde, Secretaria de Assistência Social ou Secretaria de Desenvolvimento Social. A grande maioria deles era exclusivamente voltada para o atendimento a mulheres em situação de violência. Alguns tinham foco na atenção à família, atendendo especialmente crianças e adolescentes vítimas de violência.

Dos 20 serviços psicossociais paulistas, um deles era uma unidade básica de saúde e os outros 19 serviços eram centros de referência para mulheres ou adolescentes em situação de violência. De todos os 20 serviços, somente 3 deles não tinham psicólogos na equipe. Dentre aqueles que tinham psicólogos, 13 estavam localizados na capital e 4 deles em municípios diferentes da Grande São Paulo. Três serviços eram voltados para o atendimento de crianças e adolescentes vítimas de violência doméstica e atendiam as famílias como parte do trabalho assistencial, o que incluía as mães, muitas vezes mulheres que também sofreram violência doméstica.

As casas abrigo eram os serviços estruturados para acolher e proteger mulheres em situação de risco de morte relacionado à violência doméstica. Tinham limitação de tempo de permanência e costumavam abrigar a mulher e seus filhos crianças. Além de proteger, atender e abrigar, desenvolviam atividades com objetivos de superação da situação de violência e da vitimização. Somente um serviço paulista não era exclusivo para mulheres em situação de violência doméstica, mas voltado à vulnerabilidade social. Em função da alta demanda, criou vagas para 
mulheres nesta condição, ajustando o fluxo, os atendimentos e os procedimentos de segurança, abrigando-as em local específico e sigiloso.

As atividades desenvolvidas nestas casas abrigo eram semelhantes às dos serviços psicossociais, porém estes foram classificados à parte por sua característica especial de abrigamento de mulheres em situação de risco, com regulamentação própria. Sua organização assistencial tinha ênfase no acompanhamento e orientação específicos para a situação de urgência, e procuravam atender à condição de exclusão das mulheres e filhos de seu cotidiano anterior - relações familiares, trabalho, escola - e à necessidade de proteção e reinserção das mulheres na vida social e produtiva. A tentativa de promover a superação da situação de violência era tratada tanto no âmbito das condições concretas de vida como da subjetividade. Todos eles realizavam atendimento social, que consistia em: regularização de documentos; encaminhamentos para polícia, advogados, saúde, moradia, inserção no trabalho, escola ou creche para os filhos abrigados; e acompanhamento desta "reestruturação da vida". Muitos desenvolviam outras ações, de maneiras e fluxo assistencial diversos, e podiam compor entre as seguintes atividades: grupos "de reflexão", "sócio-educativos" ou "oficinas temáticas" sobre a situação de violência, relacionamento familiar, sexualidade, gênero ou outros temas; atendimento ou acompanhamento psicológico; orientação ou assistência jurídica; cursos de capacitação ou geração de renda.

Entre as atividades para a manutenção do cotidiano e convivência na casa, estavam: atividades lúdicas e/ou educativas para as crianças; atividades de lazer em geral artesanato - para as mulheres; e reunião coletiva para resolver conflitos entre as famílias abrigadas. 
Em São Paulo, existiam 5 abrigos e todos eles contavam com psicólogos na equipe. Dois destes serviços eram governamentais, um deles vinculado à Secretaria de Segurança Pública e outro, à Coordenadoria da Mulher da prefeitura. Outros dois eram ONGs e um era fruto de um consórcio intermunicipal e estava sob administração de uma ONG.

Esta foi uma descrição geral dos serviços estudados na pesquisa sobre redes em São Paulo. A seguir, apresenta-se com maiores detalhes a descrição e análise dos serviços onde os psicólogos estavam inseridos e da inserção deles.

\section{II - Situando os psicólogos na rede assistencial paulista de atenção às mulheres em situação de violência}

Dos 109 serviços específicos da região metropolitana de São Paulo estudados na pesquisa sobre redes, 56 contavam com psicólogos na sua equipe técnica quando da realização do campo, em 2005, e foi a população de serviços do nosso estudo. Todos os 56 serviços ou programas, com exceção de dois serviços jurídicos, eram específicos no trabalho com a violência contra a mulher, doméstica ou intrafamiliar, tendo equipe ou ações específicas para isto.

Em São Paulo, esta pesquisadora participou da confecção de outros Guias de Serviços, em 1999 e 2002. Para verificar a evolução da inserção dos psicólogos na rede de serviços de São Paulo, foram utilizados o Guia de 2002 e o Guia de 2005, comparação apresentada na tabela 1 . 
Tabela 1. Comparação dos serviços específicos para assistência a situações de violência contra a mulher e daqueles com psicólogos na sua equipe técnica, em 2002 e 2005, por vocação assistencial.

Guia de Serviços - 2002 Guia de Serviços 2005

\begin{tabular}{lcc|lcc}
\hline Serviços & $\begin{array}{c}\text { Serviços c/ } \\
\text { psicólogos }\end{array}$ & Geral & Serviços & $\begin{array}{c}\text { Serviços c/ } \\
\text { psicólogos }\end{array}$ & Geral \\
\hline Abrigo & 2 & 3 & Abrigo & 5 & 5 \\
\hline Jurídico & 6 & 30 & Jurídico & 7 & 39 \\
\hline Orientações básicas & 3 & 7 & Orientações básicas & 5 & 9 \\
\hline Policial & 0 & 22 & Policial & 9 & 22 \\
\hline Psicossocial & 12 & 13 & Psicossocial & 17 & 20 \\
\hline Saúde & 10 & 10 & Saúde & 13 & 14 \\
\hline Total & $\mathbf{3 3}$ & $\mathbf{8 5}$ & Total & $\mathbf{5 6}$ & $\mathbf{1 0 9}$ \\
\hline
\end{tabular}

Pelas colunas Geral da tabela 1, observa-se um aumento do número de serviços específicos de 85 em 2002 para 109 em 2005, com ampliação da participação dos psicólogos, especialmente nas delegacias.

No geral, vê-se que em 2005 os psicólogos estavam em todas as categorias de serviços, ainda que com menor participação nas delegacias e nos serviços jurídicos.

A maior presença de psicólogos nos serviços de saúde, psicossociais e abrigos já era esperada, pois são áreas que têm maior tradição quanto à inclusão do psicólogo na equipe assistencial, e além disso, foram serviços nos quais este profissional estava previsto nos documentos normativos do Ministério da Saúde e da Secretaria Especial de Políticas para as Mulheres.

Chamou a atenção que nem todos os serviços psicossociais tinham psicólogos, já que seriam profissionais importantes e centrais no trabalho assistencial previsto pelos protocolos. Aparentemente, isto teve relação com a proposta assistencial destes três serviços, e será comentado mais adiante, a partir dos dados sobre atividades e equipe multiprofissional. 
Os 56 serviços específicos de São Paulo que contavam com psicólogos na equipe técnica foram listados na tabela 2 a seguir. Pelo compromisso ético de sigilo quanto à identificação dos profissionais e dos serviços, foram identificados com siglas, composta por letra referente à categoria no qual se insere e números. Desta forma, $\mathrm{P}=$ policial, $\mathrm{J}=$ jurídico, $\mathrm{S}=$ saúde, $\mathrm{OB}=$ orientações básicas, $\mathrm{A}=$ abrigo $\mathrm{e}$ $\mathrm{PS}=$ psicossocial

Tabela 2. Serviços específicos na assistência a situações de violência contra a mulher/ doméstica/ intrafamiliar, com psicólogos na equipe técnica.

\begin{tabular}{|c|c|c|}
\hline Serviço & Caráter do serviço & Psicólogos \\
\hline P1 & $\begin{array}{l}\text { Governamental / Secretaria Segurança } \\
\text { Pública }\end{array}$ & 5 psi e estagiários \\
\hline $\mathbf{P 2}$ & Governamental/ SSP & 4 estagiários \\
\hline P3 & Governamental/ SSP & 1 estagiários \\
\hline $\mathbf{P 4}$ & Governamental/ SSP & 4 estagiários \\
\hline $\mathbf{P 5}$ & Governamental/ SSP & 3 \\
\hline P6 & Governamental/ SSP & 4 estagiários \\
\hline $\mathbf{P 7}$ & Governamental/ SSP & 4 estagiários \\
\hline $\mathbf{P 8}$ & Governamental/ SSP & 1 voluntária +3 estag \\
\hline $\mathbf{P 9}$ & Governamental/ SSP & $2+2$ estagiários \\
\hline $\mathbf{J 1}$ & $\begin{array}{l}\text { Governamental / Procuradoria Geral do } \\
\text { Estado }\end{array}$ & 3 \\
\hline $\mathbf{J 2}$ & Governamental / PGE & 11 \\
\hline $\mathbf{J 3}$ & Universitário & 1 \\
\hline $\mathbf{J 4}$ & Não governamental & $14+4$ voluntários \\
\hline $\mathbf{J 5}$ & Universitário & 3 estagiários \\
\hline J6 & Não governamental & 2 \\
\hline $\mathbf{J} 7$ & Não governamental & 1 \\
\hline S1 & Governamental / Hospital das Clínicas & 1 \\
\hline $\mathbf{S 2}$ & $\begin{array}{l}\text { Governamental / Secretaria Municipal } \\
\text { Saúde }\end{array}$ & 1 \\
\hline $\mathbf{S 3}$ & Governamental / SMS & 1 \\
\hline S4 & Governamental / SMS & 1 (aborto) +4 do hospital \\
\hline S5 & Governamental / Federal & 2 \\
\hline S6 & Governamental / SMS & $4+4$ estagiários \\
\hline $\mathbf{S 7}$ & Governamental / SMS & 1 \\
\hline S8 & Governamental / SMS & 1 \\
\hline S9 & Governamental / SMS & 1 \\
\hline S10 & Governamental / SMS & 1 \\
\hline
\end{tabular}


(continuação)

\begin{tabular}{|c|c|c|}
\hline Serviço & Caráter do serviço & Psicólogos \\
\hline S11 & Governamental / SMS & 2 \\
\hline $\mathbf{S 1 2}$ & Governamental / SMS & 1 \\
\hline S13 & Governamental / SMS & 2 \\
\hline OB1 & Não governamental & 3 \\
\hline OB2 & Governamental / SMS e Santa Casa & 1 \\
\hline OB3 & $\begin{array}{l}\text { Governamental / Coordenadoria da } \\
\text { Mulher }\end{array}$ & 1 \\
\hline OB4 & Governamental/ SMS & 1 \\
\hline OB5 & Governamental/ SMS & 2 \\
\hline A1 & Governamental / Coord Mulher & 1 coord +1 estagiária \\
\hline A2 & Consórcio intermunicipal & 1 ou mais (externo) \\
\hline A3 & Governamental/ SSP & 1 \\
\hline A4 & Não governamental & 2 \\
\hline $\mathbf{A 5}$ & Não governamental & 1 \\
\hline PS1 & Governamental / Coord Mulher & $1+1$ estag \\
\hline PS2 & Governamental / Coord Mulher & $2+2$ estag \\
\hline PS3 & $\begin{array}{llll}\text { Governamental } & / & \text { Secretaria } & \text { de } \\
\text { Assistência Social } & & \\
\end{array}$ & 1 \\
\hline PS4 & Governamental / SAS & 3 \\
\hline PS5 & $\begin{array}{l}\text { Governamental / Secretaria Cidadania e } \\
\text { Assistência Social }\end{array}$ & 1 \\
\hline PS6 & $\begin{array}{l}\text { Governamental / Secretaria de Inclusão } \\
\text { Social }\end{array}$ & $4+1$ estag \\
\hline PS7 & Governamental / Coord Mulher & 1 \\
\hline PS8 & Governamental / SAS & $1+1$ estag \\
\hline PS9 & Não governamental & 2 \\
\hline PS10 & Não governamental & 2 \\
\hline PS11 & Não governamental & 8 \\
\hline PS12 & Não governamental & 4 \\
\hline PS13 & Não governamental & 1 \\
\hline PS14 & Governamental/ SMS & 1 \\
\hline PS15 & Governamental / HC e USP & $2+4$ estag \\
\hline PS16 & Não governamental & 13 \\
\hline PS17 & Governamental / SMS e USP & 2 \\
\hline
\end{tabular}

Chamou a atenção o vínculo dos profissionais de psicologia atuantes nestas instituições. A presença importante de estagiários e voluntários apontou para a precariedade do trabalho assistencial destes profissionais, pois remeteria a um vínculo de trabalho frágil, com rotatividade alta, em função da permanência de 
estagiários pelo período de no máximo 1 ano. Por outro lado, viu-se que as DEAMs e alguns serviços de outras categorias configuraram-se como campo de estágio para a formação de futuros psicólogos, demonstrando que a violência contra a mulher já faria parte da formação atual em psicologia, contexto que não existia até alguns anos atrás.

Notou-se que muitos serviços tinham somente estagiários de psicologia ou profissionais voluntários na equipe. Nas delegacias, a maior parte delas contava exclusivamente com estagiários (P2, P3, P4, P6, P7) para o desenvolvimento das atividades de apoio psicológico e uma ainda (P8) tinha sua equipe de psicologia formada por uma profissional voluntária e três estagiárias. Além das delegacias, uma casa abrigo (A2) contratava temporariamente uma ou mais psicólogas, conforme a necessidade e possibilidade, para supervisão da equipe e atendimento às crianças e adolescentes. Eram psicólogas externas, autônomas, que não faziam parte da equipe fixa. E um serviço jurídico (J5) contava exclusivamente com 3 estagiários de psicologia para realizar acompanhamento psicológico durante o período de encaminhamento dos processos jurídicos.

Este quadro evidenciou a demanda por psicólogos na equipe assistencial e uma possível dificuldade institucional de contratação de psicólogos. Esta precariedade no vínculo profissional nos serviços policiais, em um abrigo e um serviço jurídico poderia indicar uma dificuldade de apoio institucional para a composição de equipes fixas, com baixa valorização do trabalho (pelo menos no nível gestor) do psicólogo. Vale lembrar a baixa institucionalização dos serviços, vista pela instabilidade das equipes e dos serviços como um todo. Comparando os serviços do Guia de 2002 e os do Guia de 2005, percebe-se que alguns serviços não 
foram extintos e muitos outros foram criados. Entre os que permaneceram, alguns que tinham psicólogos na equipe não contavam mais com este profissional. Este quadro de precariedade institucional possivelmente teve relação com as dificuldades quanto ao financiamento e apoio às ONGs, mas também com a instabilidade das políticas para os serviços voltados ao atendimento a situações de violência contra a mulher, além da instabilidade das políticas de governo.

A tensão nos serviços policiais que mostramos nos primeiros capítulos foi confirmada nos resultados do nosso estudo. Nas DEAMs, pelo menos no projeto inicial feminista, também estavam previstos psicólogos, assim como assistentes sociais. Mas pelo já exposto a partir da pesquisa do CNDM (Silva, 2002), esta inserção dos psicólogos não se efetivou, tendo poucas delegacias brasileiras incorporando estes profissionais no seu quadro de pessoal, apesar das policiais identificarem sua necessidade. Em São Paulo, parece que as delegacias só incorporaram psicólogas depois de 2002, ainda assim, basicamente como estagiários. É interessante dizer que entre as DEAMs paulistas que não tinham psicólogos na equipe (13 delegacias), boa parte relatou que gostaria de ter este profissional (7 delegacias), quando perguntadas sobre atividades importantes e não existentes para o desenvolvimento do trabalho na instituição. A norma técnica de padronização para DEAMs, publicada em 2006 - um ano depois da realização do campo da pesquisa sobre redes -, aparentou tentar resolver esta tensão, orientando que o melhor lugar para desenvolver a assistência psicológica seria nos centros de referência, abrigos e serviços de saúde, orientando ainda o referenciamento mútuo.

Vejamos melhor como ocorreu a inserção dos psicólogos nos serviços específicos, considerando as características dos serviços. Para tanto, levou-se em 
conta principalmente atividades assistenciais desenvolvidas pelos psicólogos e equipe multiprofissional. Lembramos que as respostas foram fornecidas por gerentes e técnicos da assistência, e não necessariamente pelos psicólogos. Nos 56 serviços estudados, 19 psicólogos responderam ao questionário, sendo 1 de serviço jurídico, 1 de policial, 3 de orientações básicas, 8 de psicossociais, 5 de saúde e 1 de abrigo. os resultados refletiram, portanto, a percepção dos profissionais em geral, que poderiam não estar apropriados ou afinados com a proposta de trabalho específica do psicólogo.

$\mathrm{Na}$ Tabela 3, foi apresentada a configuração geral das atividades dos psicólogos, lembrando que houve variações em cada serviço entrevistado.

Quanto à equipe, a descrição correspondeu aos profissionais citados por todos os profissionais entrevistados em cada categoria de serviços, em ordem decrescente de freqüência de citações. Referiram-se à equipe específica, que atuava exclusivamente ou compondo com outras atividades no atendimento às situações de violência. Houve grande variação na composição e poucos tinham a equipe "completa" descrita na sistematização abaixo. A Tabela 3 refere-se aos 56 serviços que tinham psicólogos. 
Tabela 3. Caracterização dos serviços específicos com psicólogos, conforme atividades desenvolvidas e equipe técnica.

\begin{tabular}{|c|c|c|c|}
\hline Serviço & $\begin{array}{l}\text { Vocação assistencial } \\
\text { do serviço }\end{array}$ & Atividades do psicólogo & $\begin{array}{l}\text { Composição da } \\
\text { equipe }\end{array}$ \\
\hline Abrigo & $\begin{array}{l}\text { Abrigo e proteção a } \\
\text { mulheres em } \\
\text { situação de risco de } \\
\text { vida, por violência } \\
\text { doméstica. }\end{array}$ & $\begin{array}{l}\text { Sócio-educativas e de } \\
\text { apoio (acompanhamento, } \\
\text { orientação e reflexão) de } \\
\text { caráter social, supervisão } \\
\text { técnica para a equipe. }\end{array}$ & $\begin{array}{l}\text { Psicólogo, } \\
\text { assistente social, } \\
\text { educadores, } \\
\text { policial (guarda, } \\
\text { investigador), } \\
\text { advogado. }\end{array}$ \\
\hline Jurídico & $\begin{array}{l}\text { Assistência e } \\
\text { orientação jurídica na } \\
\text { área de família. }\end{array}$ & $\begin{array}{l}\text { Mediação de conflitos, } \\
\text { acolhimento psicológico } \\
\text { como apoio ao trabalho } \\
\text { jurídico. }\end{array}$ & $\begin{array}{l}\text { Advogado, } \\
\text { assistente social, } \\
\text { psicólogos, } \\
\text { mediadores. }\end{array}$ \\
\hline Policial & $\begin{array}{l}\text { Registro de } \\
\text { ocorrência e } \\
\text { investigação de } \\
\text { crimes de violência } \\
\text { contra mulheres. }\end{array}$ & $\begin{array}{l}\text { Suporte emocional de } \\
\text { urgência, e orientação } \\
\text { geral ou sobre direitos. }\end{array}$ & $\begin{array}{l}\text { Policial } \\
\text { (delegada, } \\
\text { escrivã, } \\
\text { investigadores), } \\
\text { psicólogo, } \\
\text { advogado, } \\
\text { assistente social. }\end{array}$ \\
\hline Psicossocial & $\begin{array}{l}\text { Fortalecimento das } \\
\text { mulheres e } \\
\text { ampliação dos } \\
\text { recursos sociais e } \\
\text { institucionais para o } \\
\text { enfrentamento da } \\
\text { violência contra a } \\
\text { mulher. }\end{array}$ & $\begin{array}{l}\text { Atendimento } \\
\text { psicológico; atividades } \\
\text { educativas, de orientação } \\
\text { ou prevenção; grupos e } \\
\text { oficinas diversos; } \\
\text { atividades corporais; } \\
\text { suporte e formação para } \\
\text { profissionais. }\end{array}$ & $\begin{array}{l}\text { Psicólogo, } \\
\text { assistente social, } \\
\text { psiquiatra, } \\
\text { advogado, } \\
\text { médico, } \\
\text { educador. }\end{array}$ \\
\hline Saúde & $\begin{array}{l}\text { Assistência à saúde e } \\
\text { psicossocial a } \\
\text { mulheres em } \\
\text { situação de violência, } \\
\text { especialmente } \\
\text { violência sexual. }\end{array}$ & $\begin{array}{l}\text { Avaliação do } \\
\text { comprometimento } \\
\text { psicológico, } \\
\text { acompanhamento para } \\
\text { retomada da vida sexual, } \\
\text { elaboração da situação } \\
\text { de violência, } \\
\text { acolhimento e orientação } \\
\text { sobre DST. }\end{array}$ & $\begin{array}{l}\text { Psicólogo, } \\
\text { assistente social, } \\
\text { médicos } \\
\text { diversos, } \\
\text { enfermagem. }\end{array}$ \\
\hline $\begin{array}{l}\text { Orientações } \\
\text { Básicas }\end{array}$ & $\begin{array}{l}\text { Escuta e orientação } \\
\text { sobre direitos, saúde } \\
\text { da mulher e rede de } \\
\text { serviços voltados } \\
\text { para situação de } \\
\text { violência. }\end{array}$ & $\begin{array}{l}\text { Acompanhamento } \\
\text { psicológico, orientação e } \\
\text { acolhimento para } \\
\text { situações de violência e } \\
\text { saúde da mulher (sobre } \\
\text { direitos e serviços da } \\
\text { rede). }\end{array}$ & $\begin{array}{l}\text { Psicólogo, } \\
\text { assistente social, } \\
\text { médico, } \\
\text { enfermagem. }\end{array}$ \\
\hline
\end{tabular}




\section{Sobre as equipe multiprofissionais}

Os psicólogos estavam quase sempre inseridos em equipes com 3 ou mais profissionais de formações diferentes, o que pode representar possibilidades de constituição de equipes mais complexas e trabalhos interdisciplinares, com uma compreensão do objeto e de seus objetivos como composição de trabalhos de diferentes formações profissionais.

Dois serviços psicossociais foram exceções quanto ao aspecto da multiprofissionalidade, pois suas equipes se restringiram aos psicólogos.

Um deles trabalhava especialmente com violência sexual incestuosa, desenvolvendo atividade de psicoterapia familiar e quando havia necessidade, realizava também psicoterapia individual com as crianças e adolescentes ou com seus familiares. Recebia sua demanda da Vara da Infância, um hospital referência para violência sexual e conselhos tutelares, e restringiam sua clientela àqueles cujo abuso sexual já havia sido denunciado na justiça. Configurava-se, desta forma, como serviço de saúde mental de referência para o trabalho jurídico. Quando encaminhava sua clientela, o fazia apenas para serviços de saúde mental.

O outro serviço, bem diferente deste, era uma ONG feminista, com equipe reduzida de 4 pessoas (3 psicólogas e 1 psicanalista), e tinha por objetivo a "organização e formação das mulheres para a defesa de seus direitos". Realizavam diversas atividades terapêuticas, de apoio social e de orientação, como: terapia de grupo, atendimento individual, terapia comunitária, oficinas sobre saúde e oficinas de trabalho manuais. Quando inquiridos sobre a atividade importante e inexistente para o desenvolvimento do trabalho na instituição, só relataram sentir falta de um trabalho de prevenção de DST (doenças sexualmente transmissíveis) e gravidez com 
adolescentes de comunidades pobres. Relataram ter intensa relação com serviços da comunidade (da rede geral) e com diversos serviços da rede específica, para orientação e assistência jurídica, abrigamento, atendimento de saúde. Com isso, aparentemente complementavam suas ações multiprofissionais por meio de outros serviços da rede específica e geral, e pode-se dizer que o trabalho se configurava como orientação e apoio psicossocial às mulheres.

Nenhum deles parecia sentir falta de outros profissionais, por razões diferentes. Um se colocava como referência de saúde mental especializada em violência para alguns serviços jurídicos e o outro fazia a articulação

multiprofissional por meio de serviços diversos da rede específica para situações de violência e da rede geral. Desta forma, ter uma equipe multiprofissional pareceu ser menos importante para efetivamente realizar a articulação de assistências diversas do que a concepção sobre o problema e o reconhecimento da importância de compor os trabalhos e formar a rede.

Também notou-se que 3 serviços psicossociais, todos ONGs, não tinham psicólogos na equipe.

O primeiro contava com advogados, estagiários de direito, assistente social e terapeuta ocupacional, e oferecia as seguintes atividades: assistência jurídica, grupo de apoio, cursos sobre direitos da mulher, curso de capacitação em empreendedorismo para geração de renda, alfabetização de adultos. Quando perguntados sobre a atividade importante e inexistente na instituição, relataram sentir falta de um trabalho de geração de renda, para o qual estavam buscando parcerias. A entrevistada entendia que "às vezes as mulheres voltam para o agressor (marido) por não ter renda". 
O segundo serviço contava com equipe de pedagogos, assistente social, advogado e educadores, realizando as seguintes atividades: atendimento social, atendimento jurídico, grupo de auto-ajuda, grupo de formação e gênero, brinquedoteca, atendimento individual das mulheres em situação de violência, oficinas de artesanato e de corporialidade. Tinham em sua clientela principal adolescentes em situação de risco, mas em função da demanda, incluíram também as mulheres adultas nas atividades voltadas para situações de violência doméstica. Quando perguntados sobre uma atividade fundamental para o desenvolvimento do trabalho e não existente na instituição, citaram a necessidade de uma psicóloga, "porque demoraria menos tempo para a mulher admitir que está em situação de violência".

Observou-se, a partir desta fala, uma concepção sobre o trabalho do psicólogo que seria próximo da compreensão da SPM expressada na norma técnica para centros de referência (2006b). Nesta norma técnica, orientaram que o psicólogo atuasse na internalização, pelas mulheres atendidas, de que a violência seria inadmissível em qualquer situação.

O terceiro serviço era voltado a mulheres em condição de prostituição e baixa renda, com o objetivo de trabalhar a situação de risco social e violência em geral, incluindo violência doméstica. A equipe técnica era composta por educadores, oficineiros, enfermeira e assistente social. As atividades desenvolvidas consistiam em: triagem; oficinas de biodança e arte (com objetivo terapêutico e de geração de renda); atendimento dos educadores; acompanhamento da mulher; plantão de rua; orientação jurídica; atendimento social; orientação sexual e saúde. 
Observou-se que estes três serviços tinham propostas assistenciais de fortalecimento das mulheres, como todos os serviços psicossociais, sendo que o primeiro colocava ênfase nos aspectos de inclusão social e assistência jurídica, o segundo em atividades mais educativas e de fortalecimento individual, e o terceiro em atividades de saúde sexual e orientações de direitos. Estas propostas estavam de acordo com o recorte que faziam sobre o problema da violência contra a mulher, direcionando as ações para clientela específica (mulheres em situação de violência doméstica, adolescentes em situação de risco social e prostitutas de baixa renda), organizando a assistência e as equipes de acordo com estas especificidades.

Somente um relatou a necessidade de psicólogo na equipe, porém, com a função de ajudar a mulher a admitir mais rápido que "estava em situação de violência". Aparentemente, os profissionais entrevistados destes serviços não compreenderam o trabalho do psicólogo como essencial para o trabalho desenvolvido na instituição. Porém, desenvolviam trabalhos semelhantes aos outros serviços psicossociais que contavam com psicólogos, como pode-se ver a seguir. Isto demonstrou o grande campo de trabalho comum que o objeto pode propiciar e a dificuldade de delinear a especificidade destes profissionais.

\section{Sobre as atividades assistenciais do psicólogo}

Com as atividades realizadas pelos psicólogos (incluindo os estagiários e voluntários), notou-se a diversidade de intervenções e pôde-se vislumbrar aspectos de sua inserção na equipe multiprofissional.

Viu-se que os psicólogos estavam inseridos nas equipes diferentemente, conforme a vocação assistencial. Apesar da grande maioria - com exceção dos 
abrigos e dos serviços jurídicos - relatarem desenvolver atividades clínicas ou psicoterapêuticas, elas tinham caráter diferenciado, como foi apresentado na tabela 3. O trabalho clínico tradicional foi a atividade assistencial mais constante nos serviços, com variações no formato (atendimento individual, em grupo, família, casal) e pareceu ser a atividade específica e própria do psicólogo. Houve variações também quanto ao foco da assistência, que acompanhou a vocação assistencial dos serviços onde se inseriam. Mas algumas atividades desenvolvidas pelos psicólogos que eram compartilhadas com assistentes sociais, educadores e outros profissionais, que consistiram no trabalho mais geral de fortalecimento, orientação sobre direitos, orientações sobre os recursos sociais, triagem e atividades lúdicas e/ou de relaxamento.

A seguir, serão apresentadas como se configuram as atividades assistenciais dos psicólogos nos serviços, conforme a vocação assistencial.

\section{Serviços policiais}

Nos serviços policiais, a proposta foi propiciar apoio emocional, com o caráter de acolhimento de urgência. Em alguns, os psicólogos também faziam orientação sobre direitos e sobre as conseqüências formais e legais da denúncia, auxiliando na decisão de fazer ou não o boletim de ocorrência, além de realizarem os encaminhamentos externos - que não se restringiam aos serviços de saúde mental. Somente um destes serviços (P1) tinham assistente social.

Os serviços P9 e P8 ainda citaram a avaliação psicológica de violência sexual. P1 e P6 atendiam também casais. Somente P1, P2 e P3 disseram realizar terapia individual ou grupal. Em P1, além da terapia individual, de casal e de grupo, 
o psicólogo ainda fazia triagem, antes do registro do BO; avaliação de agressores e vítimas; e "grupo de musicoterapia". Este grupo de musicoterapia era realizado após o atendimento psicológico, com o intuito de relaxamento, alivio da tensão, e era feito em dupla com a delegada.

Pelos relatos dos entrevistados, em geral, os psicólogos acolhiam situações identificadas pelos entrevistados com "pessoas angustiadas", "fragilidade", "urgências" ou "pessoas que precisam de apoio emocional", "para as pessoas se conhecerem e trocarem informações”, “para conversar, desabafar". Uma DEAM, quando inquirida sobre atividades importantes e inexistentes no serviço, disse não faltar nada, porém seria preciso melhorar o atendimento já realizado pelas policiais, porque "às vezes a pessoa quer conversar", reconhecendo, assim, que o acolhimento e escuta não deveriam se restringir aos psicólogos, mas seria parte também do trabalho das policiais.

Cabe aqui retomar algumas discussões já apresentadas no início do capítulo: a dificuldade das policiais quanto às tarefas de escuta e acolhimento e a conseqüente identificação do problema da violência doméstica - ou parte dele - com necessidades compreendidas como de ordem psicológica. Pelos resultados obtidos, os psicólogos também foram chamados a preencher uma lacuna importante da capacitação das policiais, que seria do acolhimento, escuta qualificada, ou seja, do atendimento humanizado. Ao deslocar estas tarefas para o psicólogo, também fizeram outro deslocamento com relação à queixa das mulheres: a queixa policial, que se configurava como crime e violação de direitos pode ter sido tratado como problema individual e privado, de âmbito subjetivo, por vezes descaracterizando a queixa ou não realizando a demanda de intervenção policial. O que poderia ser uma 
articulação destas dimensões do problema da violência de gênero talvez tenha se transformado em desqualificação do mesmo enquanto objeto para a polícia e para a justiça. É importante lembrar que o fortalecimento dessas mulheres também ocorreria pelo reconhecimento dos seus direitos e das agressões enquanto violência.

\section{Serviços de saúde}

Nos serviços de saúde voltados para situações de violência sexual, tanto aqueles que prestavam assistência somente a estas situações como aqueles que também realizavam aborto previsto em lei, o trabalho do psicólogo tinha o caráter de avaliação do impacto emocional e acompanhamento ou elaboração da situação de violência, alguns com foco na retomada da vida sexual pela mulher.

Porém, estes serviços apresentaram diferenças. Naqueles que não faziam o aborto, os psicólogos realizavam, geralmente, atividades iguais a de outros profissionais da equipe, no acolhimento, orientação e profilaxia de DSTs, além das atividades clínicas específicas (psicoterapia, acompanhamento, orientação, diagnóstico). Alguns destes serviços disseram atender, em menor volume, demandas de violência doméstica (física e/ou sexual). Mas pareceu, pelo relato de casos típicos, que a violência sexual atendida em sua maioria foi de violência sexual por estranhos. Um serviço chegou a dizer que não atendia violência doméstica, por não ter pessoal qualificado.

Já nos 7 serviços que realizavam também o aborto legal, os psicólogos faziam basicamente avaliação ou diagnóstico do que definiram como comprometimento psicológico relacionado à violência ou à gravidez de risco e acompanhamento ou psicoterapia no modelo ambulatorial. Um deles (S6) ainda 
fazia avaliação para a Justiça e orientação aos pais, quando a violência sexual era cometida contra crianças.

Confirmando as impressões comentadas nos capítulos 1 e 2, viu-se, pela descrição das atividades assistenciais das equipes, que os serviços de saúde (hospitais e ambulatórios) centravam o atendimento à mulheres em situação de violência nos casos de violência sexual por estranhos, com ênfase nas ações biomédicas. A violência doméstica apareceu nas demandas dos serviços, porém com menor intensidade e em geral, tratava-se de violência física por companheiros. A violência sexual por parceiros parece ter sido praticamente invisível, pelo observado nos relatos dos casos típicos e atípicos atendidos por estes serviços. Lembrando as considerações de Schraiber (2001) e Kiss (2004), esta invisibilidade poderia ter relação com a falta de instrumentos para lidar com estas situações e com o não reconhecimento de que seriam demandas pertinentes para os serviços de saúde, ou seja, não teriam sentido assistencial para os profissionais de saúde.

Notou-se também que a realidade dos serviços foi semelhante às orientações das Normas Técnicas, que estavam voltadas para as situações de violência sexual e não traziam propostas de intervenção compatíveis aos casos de violência doméstica em geral, nem de violência sexual por parceiro. O trabalho do psicólogo era bem delineado, com tarefas específicas e outras compartilhadas com outros profissionais, havendo articulação das ações entre a equipe, centrado nesta demanda específica.

\section{Serviços de Orientações Básicas}

Nos serviços de Orientações Básicas, também voltados para a saúde, observou-se que a assistência a mulheres em situação de violência era bastante 
diferenciada dos demais serviços de saúde. Eram unidades básicas e ONGs que desenvolviam atividades de orientação e acolhimento da situação de violência, com possibilidade de acompanhamento psicoterapêutico. Atendiam basicamente situações de violência doméstica contra mulheres e crianças. Tinham fluxo específico para o atendimento a situações de violência, sendo que em duas UBS não havia restrição de área de abrangência para estes casos. Dois serviços eram ONGs que trabalham com foco na saúde da mulher e tinham relações com o movimento de mulheres.

Os psicólogos realizavam atividades de orientação sobre a situação de violência, sobre direitos, sobre as instituições e serviços da rede, às vezes em conjunto com outros profissionais, além do trabalho específico de acompanhamento psicológico ou psicoterapia (individual ou em grupo). Este trabalho próprio e exclusivo foi definido como atendimento de saúde mental, sugerindo não ser assistência específica, com direcionamento para as situações de violência, mas como atendimento da rede geral.

Aparentemente, foi nos serviços de atenção primária que a violência doméstica (física e sexual) teve algum reconhecimento na área da saúde, apesar de terem sido poucos serviços que se estruturaram para atender esta demanda. No geral, o psicólogo dividia as tarefas de acolhimento inicial e orientação com outros profissionais, sendo que suas atividades assistenciais próprias e exclusivas eram aquelas tradicionais da psicologia clínica, possivelmente sem especificidade para a clientela que sofre violência.

Semelhante às orientações e normatizações da norma técnica para DEAMs (SPM, 2006), dos Cadernos de Atenção Básica (MS, 2001) e do protocolo para 
casas-abrigo (SPM, 2003), os serviços estudados estruturaram o atendimento psicológico como de saúde mental, não específico para situações de violência, remetendo o atendimento psicológico especializado para os centros de referência e casas abrigo.

\section{Serviços psicossociais}

Nos serviços psicossociais, os psicólogos realizavam atividades clínicas de toda ordem, além de atividades sociais e educativas, com diversos graus de reflexão política e de gênero nestas práticas, como visto na tabela 3.

Com exceção das atividades clínicas, as outras atividades desenvolvidas não eram exclusivas dos psicólogos e em alguns serviços eramrealizadas por outros profissionais não psicólogos (assistentes sociais, terapeutas alternativas e terapeutas ocupacionais), como: grupo de auto-ajuda, grupo de terapia comunitária, terapias alternativas, grupo de saúde da mente, grupo de auto-cuidado. Estas atividades também tinham os objetivos de fortalecimento das mulheres e de "resgate da autoestima", não eram próprias de psicólogos e não havia informações de como (e se) eram articuladas com as atividades clínicas destes.

Duas instituições não realizavam atendimento clínico psicológico, sendo que este profissional desenvolvia atividades iguais ou em conjunto com os outros técnicos da casa. No serviço PS2, o psicólogo realizava grupo de tai-chi-chuan; atividades que assistente social e estagiários também executavam: triagem, acompanhamento individual (para avaliar e refletir com as usuárias as questões que as aprisionariam e impediriam o rompimento da situação de violência - objetivas e subjetivas), grupos (cujos temas eram: HIV, relações de gênero, identidade, oficinas 
capacitação, culinárias, entre outros), encaminhamentos externos. No serviço PS5 o psicólogo participava de todas as atividades do centro, como toda a equipe - grupo de auto-ajuda, palestras e oficinas, grupo de mulheres no bairro, curso de bijuteria, pintura, artesanato, tricô.

Observou-se que o psicólogo tinha funções e lugares variados, não necessariamente exclusivos. Esta variação poderia ter relação com as representações das equipes e da coordenação dos serviços sobre os atendimentos psicológicos. Provavelmente também teria relação com as próprias concepções dos psicólogos sobre as suas habilidades (próprias da sua formação e outras), e sobre as possibilidades de sua inserção e articulação de ações nas propostas assistenciais de cada serviço, além das concepções sobre violência de gênero e dos instrumentos adequados para intervir no problema.

Em alguns serviços ainda os psicólogos desenvolviam atividades de formação ou suporte para os profissionais da equipe ou de outros serviços, o que confirmou a impressão comentada no capítulo 2 sobre o lugar possível para estes profissionais na capacitação e supervisão dos profissionais em geral que trabalham com situações de violência.

A realização de capacitação e supervisão para a equipe interna ao serviço e para outros serviços da rede reafirmou o lugar dos centros de referência, não só como local para encaminhamentos, mas também para a formação continuada dos profissionais. Evidenciou, desta forma, que as orientações da SPM nas normas técnicas para centros de referência (SPM, 2006) já eram realidade em alguns serviços paulistas. 


\section{Casas-abrigo}

Nos abrigos estudados, os psicólogos realizavam atividades sócio-educativas e de apoio (acompanhamento, orientação e reflexão), de caráter mais social, muitas vezes dividindo a tarefa com assistentes sociais. $\mathrm{O}$ atendimento clínico em psicologia era realizado fora, encaminhado em geral para UBS. Em todos os abrigos ficou claro o projeto comum da equipe, que era de superação da situação de risco e promoção da autonomia da mulher, que pôde ser vislumbrado pelas atividades desenvolvidas e pelas atividades que os entrevistados consideraram importantes e não existentes na instituição. As atividades desenvolvidas nos abrigos já foi apresentada na caracterização dos serviços, conforme a vocação assistencial. As atividades inexistentes e consideradas importantes para o desenvolvimento do trabalho pelos entrevistados, foram as seguintes: programas sociais de trabalho, geração de renda, moradia; vagas em creche; assistência jurídica; educadora para desenvolver trabalho com as crianças; e assistente social para realizar os encaminhamentos. Dois deles (A3 e A4) citaram ainda a necessidade de psicólogos para atendimento em grupo com as usuárias (A3) e para atendimento específico para o problema da violência, além de suporte para os profissionais, em função do trabalho estressante (A4).

Quanto à inserção dos psicólogos e as atividades desenvolvidas por eles, observou-se variações para cada serviço, que descrevemos a seguir.

Em A5 a psicóloga e coordenadora realizavam a primeira entrevista da usuária no abrigo e os encaminhamentos para atendimento psicológico ou jurídico. Também realizavam outras atividades, em conjunto com outros profissionais: atividades lúdicas e orientação escolar às crianças (realizadas em conjunto com 
educadores), mediação - oferecida ao casal e desenvolvido fora do abrigo (tarefa dividida com a assistente social).

No serviço A4, pedagoga, profissionais de enfermagem, advogado, educadores (ensino médio) e psicólogas faziam as mesmas atividades, eram chamados de multiplicadores e trabalhavam na orientação sócio-educativa (higiene, educação social, palestras, dinâmicas de grupo, lazer, encaminhamentos de saúde). $\mathrm{O}$ atendimento psicológico e psiquiátrico era feito pela UBS de referência deste abrigo.

No abrigo A1, a estagiária de psicologia fazia trabalho de recreação com as crianças (em grupo; oficinas, filme, desenhos, etc). A psicóloga tinha a função de coordenadora e realizava os encaminhamentos externos, administrava os conflitos da casa, articulava parcerias com outras instituições, grupos temáticos (onde discute sexualidade, orientação das crianças, leis referentes aos direitos das mulheres, entre outros levantados pelas abrigadas, conforme interesse e necessidade). Faziam articulação com os centros de referência para o acompanhamento das mulheres mesmo após o desligamento do abrigo. A maioria das atividades era realizada em conjunto com outras pessoas da equipe, incluindo as guardas.

Em A3, a psicóloga era a coordenadora do serviço, e além das tarefas administrativas, realizava todas as atividades assistenciais, que consistiam em: conversas individuais (para ver dificuldades e encaminhar além de conhecê-las), reunião coletiva (para resolver problemas coletivos ou de brigas entre as usuárias ou entre as crianças), encaminhamentos e acompanhamento de idas para serviços de saúde, trabalho, moradia, escola, regularização de documentos, DEAM, advogado/ procuradoria, fórum, além de orientações gerais às abrigadas. 
No serviço A2 a psicóloga contratada, em conjunto com a teóloga, realizavam a oficina sócio-educativa (com temas escolhidos pelas mulheres abrigadas), além da supervisão técnica para equipe, atendimento às crianças e adolescentes. $\mathrm{O}$ atendimento psicológico era feito por profissionais nos Centros de Referência da região.

Estes resultados reiteraram os comentários feitos na primeira parte deste capítulo, sobre a organização da assistência nos abrigos prevista no protocolo da SPM (2003), no qual o psicólogo não estava previsto para desenvolver atividades clínicas, mas de caráter social e educativo, e não tinham a princípio tarefas específicas. $\mathrm{O}$ atendimento psicológico tradicional foi remetido a UBS e a centros de referência na maioria destes abrigos estudados. No entanto, um deles (A3) encaminhava as usuárias para a UBS da região, mas a entrevistada relatou sentir necessidade de um atendimento psicológico específico para estas mulheres. Esta entrevistada demonstrou uma compreensão de que o atendimento da rede básica talvez não seja adequado ao problema.

A organização do trabalho assistencial nestes abrigos demonstrou boa articulação entre as ações dos diferentes profissionais da equipe, evidenciando também a importância da articulação com serviços da rede geral para a realização dos objetivos de reestruturação da vida cotidiana, promoção de autonomia e superação da situação de violência doméstica. Nesse sentido, a avaliação e as diretrizes preconizadas pela SPM (2003) sobre a articulação em rede de serviços aparentemente reflete uma realidade parcial, pelo menos nos serviços da região metropolitana de São Paulo. 


\section{Serviços jurídicos}

Os serviços jurídicos estudados se diferenciaram dos outros pelo fato de os psicólogos realizarem principalmente a mediação $(\mathrm{J} 1, \mathrm{~J} 2, \mathrm{~J} 3, \mathrm{~J} 4, \mathrm{~J} 6)$, uma prática compartilhada com outros profissionais e de certa forma, de apoio a procedimentos jurídicos, por tratar-se de procedimento de intermediação entre as partes com o intuito de realizar acordos jurídicos consensuais, na tentativa de superar os conflitos conjugais e não efetivar ações judiciais litigiosas. Configurou-se nestes serviços, então, uma outra prática, bastante diversa da tradicional prática clínica, mas que não seria específica do psicólogo, nem de qualquer outra profissão.

Em todos estes 5 serviços as equipes multiprofissionais desenvolviam também outras atividades assistenciais, como orientação jurídica e orientação dos direitos, atendimento social e atendimento específico para investigação de paternidade (em geral, além do processo judicial, realizavam também acolhimento e orientação dos direitos). J3 ainda realizava grupos de orientação com mulheres em processo de separação e atendimento psicológico individual. Este atendimento foi descrito como orientação às pessoas fragilizadas. J4 oferecia ainda, orientação familiar em grupo sobre gênero e violência. Estas outras atividades eram geralmente desenvolvidas por assistentes sociais, mas em alguns serviços (J4 e J6) o psicólogo também as realizava.

Quatro deles (J1, J2, J4, J6) foram criados para o atendimento a situações de violência contra a mulher. Os serviços J1 e J4 tiveram participação do movimento de mulheres na formulação inicial de sua organização assistencial, reformulando suas propostas posteriormente, incluindo o trabalho de mediação. O serviço J6 expandiu o atendimento para outras situações de violência: família, crianças e adolescentes, 
mulheres presidiárias, tráfico de mulheres, entre outros, desenvolvendo assistência que definiram como psicossocial e jurídica direcionados principalmente a mulheres, crianças e adolescentes. O trabalho desenvolvido pela equipe em J6 tinha ênfase na orientação dos direitos e assistência jurídica à população de baixa renda.

Os outros dois serviços (J5 e J7) realizavam basicamente assistência jurídica. O atendimento de orientação era realizado por psicólogos (J7) ou estagiários de psicologia (J5) e era restrito a orientações, informações e esclarecimentos sobre a demanda jurídica. Desta forma, os psicólogos desenvolviam atividades estreitamente vinculadas à assistência ou orientação jurídica e não foram fornecidas muitas informações sobre este atendimento. No primeiro, estes profissionais realizavam acompanhamento psicológico restrito aos clientes do serviço, durante o período de encaminhamento das ações judiciais. Neste, o único entrevistado se recusou a informar as atividades dos psicólogos e da assistente social, com receio de que a publicação do Guia de Serviços trouxesse demanda para estes profissionais e com isto, desviasse a proposta de assistência. No segundo, uma unidade da OAB/SP, a entrevistada deu ênfase ao trabalho de assistência jurídica e o trabalho de apoio aos advogados cadastrados, como órgão de classe. Nestes dois serviços, pareceu que o trabalho do psicólogo era visto como apoio ao trabalho jurídico, com possibilidades restritas e bem específicas de intervenção.

Notou-se que foram nas ONGs já sensibilizadas para o atendimento à violência contra a mulher que o psicólogo tinha atuação mais ampliada e talvez mais integrada com as outras ações assistenciais da equipe, compondo projeto assistencial comum. Esses eram os serviços que desenvolviam outras ações além da assistência jurídica estrita e tinham objeto de intervenção mais amplo do que a prestação de 
serviço jurídico tradicional (restrito à elaboração e ao acompanhamento de ações judiciais). O trabalho do psicólogo estava relacionado à mediação, que não seria específico nem exclusivo deste profissional. Somente um citou o atendimento psicológico específico, porém "para pessoas fragilizadas", lembrando o apoio psicológico de urgência realizado em algumas DEAMs.

Também foram estas ONGs que faziam a articulação em rede (por meio de recepção e encaminhamento de clientela) para além dos serviços policiais e jurídicos, compondo o trabalho também com centros de referência, abrigos, serviços de saúde, serviços de saúde mental, atendimentos para alcoolismo e/ou abuso de drogas, conselho tutelar. Os outros serviços jurídicos praticamente só relataram receber e encaminhar clientela para outros serviços jurídicos (Fórum e Vara da Infância)e delegacias (DEAMs e delegacias comuns).

Vale lembrar que somente 7 serviços do total de 39 serviços jurídicos paulistas incluíam psicólogos na sua equipe. Analisando as respostas dos entrevistados desses 32 serviços sem psicólogos, a respeito dos objetivos, composição de equipe, atividades desenvolvidas e atividades importantes para o desenvolvimento do trabalho e não existentes na instituição, percebeu-se que o trabalho assistencial estava organizado, no geral, sobre a assistência jurídica estrita. Os objetivos e atividades relatados descreviam os tipos de problemas jurídicos com que trabalham e as equipes são compostas por advogados e pessoal administrativo. Quando perguntados sobre as atividades inexistentes e importantes para o trabalho, somente 9 serviços relataram ser necessária alguma mudança. Mas referiram-se a melhorias no sistema judiciário, reciclagem dos estagiários e advogados, um deles 
referiu precisar de assistente social para encaminhamentos das demandas sociais e quatro identificaram a necessidade de psicólogo na equipe.

Destes 4 serviços que sentem necessidade de psicólogos para compor o trabalho, dois eram ONGs feministas e os outros dois eram serviços universitários, e tinham compreensões diferentes sobre essa necessidade.

Uma das ONGs era voltada para a assistência a mulheres em situação de violência, desenvolvia atividades de separação litigiosa e consensual (atendimento de casal e orientação), grupo de apoio (relaxamento, momento de desabafo se quiserem) e atividades de formação (seminário sobre questão da mulher, projeto sobre violência contra mulher). O trabalho do psicólogo bem como do assistente social, na visão da entrevistada, era realizado por advogados indevidamente. A outra ONG voltava suas ações para mulheres negras e desenvolvia as seguintes atividades: atendimento jurídico a vítimas de discriminação racial; atendimento jurídico às mulheres vítimas de violência doméstica e sexual; projetos sociais diversos de assistência e mobilização social; curso de promotoras legais populares com lideres comunitárias. O atendimento psicológico era descrito como trabalho de fortalecimento da auto-estima, apesar de ser uma tarefa já realizada pelo serviço. Pelos relatos das entrevistadas, parece que a proposta assistencial era idealizada com equipe multiprofissional, com advogados, psicólogos e assistentes sociais, entre outros profissionais, e não o faziam por falta de recursos financeiros. Entretanto, aparentaram desenvolver as atividades previstas, mesmo com a equipe reduzida a advogados.

Nos dois serviços universitários, os objetivos descritos eram: prestar atendimento jurídico à população de baixa renda e ensinar prática de advocacia aos 
alunos do curso de Direito. Em um deles, a atividade desenvolvida restringia-se à assistência jurídica para os casos de direito de família. O entrevistado referiu considerar interessante fazer parceria com os serviços de psicologia e de serviço social, mas não explicitou os objetivos desta parceria. No outro serviço, além da assistência jurídica, realizavam também mediação. A necessidade de psicólogo era colocada no sentido de promover à clientela auto-conhecimento, compreensão do conflito de família e "conseguir uma conciliação pacífica". Tarefa já realizada, segundo este mesmo informante, através do trabalho de mediação.

Dos 32 serviços jurídicos que não tinham psicólogos, a grande maioria (30 serviços) não reconheciam a violência contra a mulher como um problema para o seu serviço, indicando que é atual a análise de diversos autores sobre a banalização deste problema no aparato jurídico e a resistência do setor em incorporar as questões de desigualdade de gênero. (Barsted, 1994; Machado, 2002; Silva, 2002, Campos, 2003). Estes serviços eram aqueles que articulavam ações em rede praticamente só com o sistema jurídico-policial. Demonstrou, com isto, que o reconhecimento da violência contra as mulheres trouxe a necessidade de ampliar a assistência e diversificar as equipes técnicas, tanto para o interior do serviço, como na articulação em rede.

\section{Sobre a articulação multiprofissional}

Muitos dos serviços estudados, de todas as vocações assistenciais, pareceram conceber a articulação do trabalho compondo equipes multiprofissionais no próprio serviço, sendo que alguns - principalmente os abrigos - organizavam a assistência considerando a composição com serviços da rede específica e da rede geral. 
Corroborando esta análise, acrescentamos as informações sobre recebimento e encaminhamento de clientela dos serviços estudados.

Os serviços jurídicos e os policiais faziam articulação em rede com outros serviços destas mesmas vocações assistenciais, compondo uma rede própria e restrita. Entendendo que as DEAMs funcionariam como porta de entrada para o sistema judiciário, poder-se-ia afirmar que percebiam o objeto de suas intervenções como jurídico-policial e talvez por isso a inserção do psicólogo nestes serviços foi pontual. Alguns serviços policiais afirmaram receber e encaminhar clientela para serviços de saúde (em geral hospitais com atendimento para violência sexual) e psicossociais, indicando uma concepção do objeto integral mais ampliada do que nos serviços jurídicos. Os serviços de saúde também articulavam pouco com serviços de outras vocações assistenciais e quando o faziam, eram principalmente para serviços policiais (DEAM, IML), jurídicos (Vara da Infância), mas também para abrigos e serviços da rede geral (Conselho Tutelar, Secretaria de Assistência Social) com menor freqüência.

Os serviços de orientação básica, os psicossociais e os abrigos foram aqueles que mais frequentemente disseram articular ações com todos os tipos de serviços, da rede específica e da rede geral. Os de orientação básica, pelas próprias características dos serviços, funcionavam como porta de entrada na rede, pois disseram receber bastante demanda espontânea e da rede geral (escolas, conselho tutelar, UBS) e encaminhar para todas as categorias de serviços específicos. Os psicossociais recebiam e encaminhavam de todos os tipos de serviços específicos e também da rede geral, atuando como centro da rede específica e redistribuindo a clientela. Os abrigos organizavam o trabalho considerando os serviços da rede geral e da rede 
específica. Por terem endereço sigiloso (para a segurança das usuárias), quase todos os serviços estudados tinham o recebimento da clientela vinculado às DEAMs. Dois deles também estavam vinculados a serviços psicossociais. Encaminhavam para muitos serviços da rede especifica (DEAM, jurídico, psicossociais, saúde) e para variadas instituições da rede geral (escolas, creches, UBS e pronto socorros, programas sociais governamentais).

Lembrando a avaliação feita pela SPM (2003), as ações dos abrigos seriam mais efetivas quando articulados com a rede de serviços local. A articulação em rede seria fundamental para o trabalho assistencial destes serviços, que tinham por objetivo proteger as mulheres, mas também auxiliar na reconstrução da vida, na superação da situação de violência e da vitimização, além dos cuidados para a manutenção do cotidiano. Esta proposta, aliada à condição de permanência restrita na casa abrigo, implicaria em auxiliar na reinserção social da mulher e seus filhos, o que levaroa à articulação com escolas, cursos de formação profissional, programas de capacitação para trabalho, programas de moradia popular, serviços de saúde em geral, DEAMs e serviços de assistência jurídica.

Com relação à articulação de ações multiprofissionais no contexto geral dos serviços estudados, notaram-se várias formas de organizar o trabalho assistencial, desde a justaposição de trabalhos específicos, até a articulação de ações dos diversos profissionais no interior do serviço e a articulação através da rede de serviços locais.

A respeito do lugar do psicólogo na rede de serviços paulista, estes profissionais ajustavam suas ações e funções conforme a vocação assistencial do serviço no qual estavam inseridos. No policial, realizavam apoio emocional pontual e de urgência, além de orientação sobre direitos. No jurídico, faziam mediação com 
o casal, com fins de conciliação e acordo jurídico. Na saúde, distinguiram-se duas inserções: nos serviços voltados para violência sexual e/ou aborto previsto em lei, direcionavam a assistência às questões de saúde sexual e reprodutiva, elaboração da situação de violência e retomada da vida sexual; nos serviços de atenção primária, aqui categorizados como orientações básicas, faziam o acolhimento inicial, orientação dos direitos e das instituições da rede de serviços. Nos serviços psicossociais, os psicólogos compartilhavam várias atividades com outros profissionais (educativas, de inclusão social, de socialização, orientações diversas, capacitação e supervisão de outros profissionais), além de realizarem atividades clínicas (psicoterapia), todas com objetivos de fortalecimento, promoção de autonomia e elaboração da violência sofrida. Nos abrigos, as funções dos psicólogos não eram exclusivas, tinham caráter sócio-educativo (acompanhamento, orientação e reflexão), utilizando as UBS e centros de referência para o atendimento clínico de psicoterapia, com vistas à superação da situação de violência, promoção da autonomia e reestruturação da vida cotidiana.

Considerando o trabalho em rede como composição de trabalhos parcelares e complementares, sobre um projeto assistencial comum, os resultados indicaram haver uma tensão sobre o lugar do psicólogo e a especificidade do seu trabalho em cada vocação assistencial. O trabalho desenvolvido pelos psicólogos nos serviços policiais e em alguns serviços jurídicos indicou dificuldades quanto ao acolhimento e escuta da queixa das mulheres em situação de violência. Nesse sentido, a demanda por psicólogos talvez estivesse relacionada, na realidade, à necessidade de qualificação para um atendimento humanizado. O trabalho clínico tradicional que era desenvolvido nos serviços psicossociais, orientações básicas e serviços de saúde, 
com ajustes aos objetivos gerais dos serviços nos quais estavam inseridos, estavam voltados para situações de violência em alguns deles. Porém, em outros, os relatos indicaram que não eram. Além disso, muitos abrigos afirmaram remeter as usuárias para atendimento psicológico individual nas UBS, sendo que o trabalho do psicólogo do abrigo tinha caráter sócio-educativo. Com isto, levanta-se o questionamento sobre o tipo de atendimento psicológico que caberia em cada uma destas categorias de serviço e como se daria a composição entre o atendimento psicológico específico para situações de violência e o atendimento tradicional, não específico. Isto remete à discussão sobre qual seria a melhor localização para o atendimento clínico tradicional e não específico, que parece estar associado às UBS, a partir da análise dos relatos dos profissionais de abrigos e das poucas UBS estudadas, das orientações dos Cadernos de Atenção Básica (MS, 2001) e das normas técnicas para DEAMs (SPM, 2006a).

Porém, é importante lembrar que a presença de psicólogos na rede básica de saúde pareceu ser precária, assim como toda a rede de serviços de saúde mental. O recurso muito utilizado pelos profissionais entrevistados de encaminhamento para clínicas-escolas de Faculdades de Psicologia indicou que os serviços públicos provavelmente não cobriam as necessidades e demandas da população neste quesito. 


\section{CONSIDERAÇÕES FINAIS}

Concluiu-se, neste estudo, que o psicólogo foi um profissional presente e solicitado em todas as categorias de serviços da rede específica da região metropolitana de São Paulo. Nas orientações normativas do Ministério da Saúde e da Secretaria Especial de Políticas para as Mulheres, o psicólogo estava previsto para compor equipes multiprofissionais de centros de referência e casas abrigos voltados para mulheres em situação de violência, além das equipes dos serviços de saúde voltados para situações de violência sexual e serviços de atenção primária.

Este profissional foi chamado para prestar assistência às mulheres, crianças, adolescentes, casais e famílias que sofreram violência de gênero, doméstica e/ou intrafamiliar e também para atuar na capacitação e supervisão dos profissionais da rede específica.

As atividades assistenciais desenvolvidas pelos psicólogos nos serviços paulistas estavam associadas às finalidades de fortalecimento das mulheres, promoção de auto-estima, promoção de autonomia, reflexão e elaboração da situação de violência, superação da condição de vitimização, mudança nos padrões de relacionamento familiar e/ou conjugal, apoio emocional, redução de ansiedade (desabafo), acolhimento do sofrimento, orientação e esclarecimento das necessidades, intermediação do diálogo entre o casal. Estes objetivos também estavam colocados nas orientações dos documentos normativos, não só para a assistência psicológica, mas para a equipe multiprofissional como um todo. Nos serviços estudados, também se observou que essas finalidades foram relatadas nos objetivos gerais de muitos deles. Ou seja, as diversas e por vezes divergentes 
finalidades estabelecidas para o atendimento psicológico de mulheres em situação de violência estavam em sintonia com os objetivos de uma grande parte dos serviços.

Em todas as categorias de serviços notou-se grande diversidade de práticas entre os psicólogos - atividades clínicas, sociais, educativas, de orientação, mediação de conflitos -, sendo freqüente o ajustamento das práticas dos psicólogos aos objetivos e cultura hierárquica de cada categoria de serviço. No geral, como é tradicional entre os psicólogos, as atividades consideradas próprias e exclusivas deste profissional foram aquelas essencialmente clínicas, individuais ou em grupo. As exceções foram os abrigos e os serviços jurídicos, nos quais a atuação do psicólogo não era clínica e não havia delimitação clara entre as atividades do psicólogo e de outros profissionais da equipe (no caso das atividades sócioeducativas e da mediação). É interessante ressaltar que os objetivos e formas de trabalho das atividades clínicas do psicólogo podem ser variados e esta questão foi pouco tematizada pelos profissionais e mesmo pelas normas técnicas.

Com relação às atividades, ainda, foram vistas aplicações e composições diferenciadas com o trabalho da equipe, conforme a vocação da instituição e do setor (Justiça, Segurança Pública, Saúde, Assistência Social) nos quais esse profissional estava inserido. As diversas atividades realizadas conjuntamente com outros profissionais ou articuladamente a eles demonstraram possibilidade de trabalho para além da psicoterapia, abrindo espaço para novas práticas mais integradas com as ações da equipe e seus objetivos.

Foi freqüente a inserção dos psicólogos em atividades que poderiam ser exercidas por outros profissionais. Eram atividades de fato realizadas por psicólogos e outros profissionais - às vezes em conjunto com eles -, principalmente por 
assistente social, mas também por educadores, arte-terapeutas, terapeutas alternativos, advogados e policiais. Como visto, na literatura levantada e reforçada pelos relatos dos serviços paulistas estudados, as atividades com finalidade de orientação, fortalecimento e promoção de autonomia eram atribuição da equipe, na maioria dos serviços.

As atividades terapêuticas em grupo também eram realizadas em alguns serviços paulistas por assistentes sociais ou educadores, em conjunto com psicólogos ou não, como os grupos de auto-ajuda, grupos de terapia comunitária, grupos de reflexão sobre gênero e violência e oficinas terapêuticas. As atividades de acolhimento e escuta (denominadas como acolhimento, triagem, orientação) estavam presentes em quase todos os serviços e eram também realizadas por assistentes sociais, policiais, advogados ou mesmo profissionais administrativos treinados para o primeiro atendimento. No entanto, tanto as atividades terapêuticas de grupo, como as de acolhimento e escuta, foram consideradas, por profissionais de alguns serviços, como próprias do psicólogo.

Especificamente com relação ao acolhimento e escuta, que deveriam ser parte do trabalho de todos, sua identificação com o trabalho exclusivo do psicólogo evidenciou as dificuldades dos profissionais em geral de lidar com a dimensão interpessoal e com o sofrimento alheio. Identificou-se aqui uma dificuldade de efetivar o que vem sendo chamado de humanização do atendimento, ou seja, a importância de todos os profissionais acolherem e escutarem os usuários, seja em serviços de saúde, policiais ou de qualquer natureza.

No caso das atividades de grupo, terapêuticas ou não, a não distinção clara dos profissionais responsáveis pareceu indicar uma indefinição do lugar de cada 
profissional e o pouco conhecimento sobre as possibilidades de intervenção destes. As exceções foram as intervenções propostas pelos abrigos e as propostas de mediação, nas quais a indistinção do profissional que poderia exercê-las fazia parte da proposta assistencial, que tinham conteúdo próprio e objetivos claros e podiam ser realizadas a contento pelos membros da equipe.

Nos documentos normativos também havia poucas orientações para o trabalho específico do psicólogo, não existindo muitas diferenciações entre o trabalho deste e do assistente social e sendo chamado por vezes de atendimento psicossocial. Destaca-se que a dimensão psicossocial não deveria se referir somente a um tipo de atendimento, mas principalmente a aspectos do objeto integral para o qual os profissionais direcionariam suas ações. Neste sentido, os resultados deste estudo evidenciaram que a dimensão psicossocial - que teria relação com as necessidades de humanização do trabalho, demandas psicológicas, demandas sociais e aspectos culturais da clientela e dos profissionais - foi considerada como externa ao trabalho próprio e específico dos serviços policiais, jurídicos e de saúde. Utilizando o termo cunhado por Silva (2002) para distinguir o trabalho estritamente policial daquele que foi considerado extra-policial, pôde-se afirmar que o psicossocial foi visto, nestes serviços, como extra-jurídico e extra-biomédico também. Ou seja, ao atendimento psicossocial foi associada, pelos documentos normativos e pelos profissionais entrevistados, a parcela da assistência que os outros profissionais tiveram dificuldades de assumir. Esta exclusão da dimensão psicossocial provavelmente impôs limites para a integração da assistência e para definições mais claras deste atendimento e do projeto assistencial comum. 
A presença e mesmo a necessidade do psicólogo não foi consenso nem entre os serviços psicossociais e abrigos, que se apoiavam no trabalho psicossocial. Aparentemente, alguns profissionais entenderam o trabalho mais pelo seu caráter social e educativo, recorrendo aos psicólogos como profissionais clínicos e necessários em algumas ocasiões - quando remetiam a outros serviços, por vezes da rede geral, para atendimento psicoterápico. Para estes, o trabalho de superação da situação de violência e da vitimização, promoção de autonomia, mudança no padrão de relacionamento conjugal e familiar, fortalecimento pessoal e como sujeito de direitos passava pelo trabalho educativo sobre as determinações de gênero, pelo apoio social e incremento na condição social e econômica, que promoveriam maior autonomia e exercício da cidadania. Isto remeteu ao formato assistencial do SOS Mulher, que se caracterizava pelo trabalho voluntário, não especializado e de mobilização feminina contra a opressão masculina. Tinha os objetivos de proporcionar o fortalecimento das mulheres enquanto grupo e a "conscientização" sobre a condição feminina de subordinação, incluindo a violência como conseqüência da desigualdade de poder entre homens e mulheres. O recurso mais utilizado eram atividades grupais, de relatos de experiência. Em muitos dos serviços atuais, apesar da distância no tempo, pareceu ter havido influência dessa experiência assistencial do movimento de mulheres, quanto à forma de conceber o objeto de intervenção e a organização do trabalho assistencial.

Porém, nem sempre o trabalho de equipe multiprofissional nos serviços paulistas estudados indicou um projeto de trabalho comum no âmbito da rede, o que se observou principalmente pela falta de articulação das ações, especialmente nos serviços jurídicos. Menos freqüente ainda foi a articulação de ações entre os serviços 
de setores diferentes e a compreensão de que o trabalho de cada um seria parcelar e complementar ao do outro (profissional ou serviço), especialmente se este fosse de outra categoria profisssional ou outro setor assistencial, nos serviços jurídicos, policiais e da saúde.

As dificuldades de articulação possivelmente estavam associadas a divergências de compreensão sobre o problema, ou seja, divergências na concepção do objeto de intervenção. Apesar de muitos serviços terem citado a violência contra as mulheres enquanto violência de gênero, as diferenças de propostas de intervenção apontaram para concepções conflitantes em alguns aspectos. Isto ficou mais evidente nas propostas de mediação, praticadas nos serviços jurídicos e condenadas pela SPM, nas normas técnicas para centros de referência (SPM, 2006b).

Foram observadas outras divergências, sistematizadas em duas concepções polares, que puderam ser observadas mais claramente nos documentos normativos, e também nas entrevistas de alguns dos serviços estudados. Uma delas foi a compreensão de que a violência seria uma forma de resolução de conflito na família e/ou no casal, que levaria às propostas de intervenção visando a promoção do diálogo e mudanças no padrão de relacionamento familiar e/ou conjugal. A outra foi uma visão mais estereotipada da mulher como vítima, dependente financeiramente e não sujeito de direitos, para a qual seria necessário "conscientizar" sobre a sua condição social de opressão. Na prática destes serviços, estas concepções pareceram se mesclar e nem sempre eram conflitantes. Nestas duas posições poderia não haver a compreensão do objeto na perspectiva de gênero. A primeira, por não considerar a desigualdade de gênero na gênese da violência contra a mulher. A segunda, por essencializar e cristalizar a posição de mulheres e homens nos conflitos vividos. 
Nestes dois casos, entendeu-se que poderia haver uma redução do problema da violência de gênero (quanto aos aspectos relacionais, sociais e políticos de sua dinâmica e gênese e quanto às intervenções propostas para a clientela), individualizando e privatizando a solução do problema. Os profissionais, quando se referiram a estes objetivos, pareceram também psicologizar a questão, destacando o psicólogo como o profissional capacitado para trabalhar estas dimensões.

É importante ressaltar que a emancipação das mulheres e a superação da desigualdade de gênero dizem respeito ao contexto cultural, social, político e institucional, onde os direitos individuais não estão garantidos. Portanto, tornar-se sujeito de direitos não seria uma questão individual e privada, mas social e política. Além disso, as mulheres vitimizadas e dependentes afetiva e financeiramente, são aquelas que vivem violências mais graves e crônicas, muitas vezes isoladas do convívio social e familiar, constituindo o grupo que necessita de abrigo para proteção e reestruturação da vida. Outras mulheres, mesmo sofrendo violência crônica por parceiro íntimo, muitas vezes trabalham, sustentam a família e não se consideram vítimas.

Estas diferenças de concepção poderiam representar dificuldades para o diálogo e a composição de ações entre os serviços, e seus profisssionais comprometendo a construção de projeto assistencial comum, na equipe e na rede.

Para melhor articulação da rede e das equipes seria importante também a distinção clara dos trabalhos específicos, para que não ocorressem sobreposições de funções e para que a complementariedade dos trabalhos dos diferentes profissionais estivesse articulada em projeto assistencial comum. Com relação ao trabalho do psicólogo, ficaram alguns questionamentos que consideramos importantes para essa 
delimitação: se o trabalho clínico de psicólogos para as situações de violência seria um trabalho com alguma especificidade própria relativa ao objeto ou não; se o trabalho de psicoterapia nos casos de violência deveria ser realizado nos serviços especializados ou na rede básica de saúde; de que forma e com que objetivos deveria ser configurado o trabalho dos psicólogos dirigidos às situações de violência; nas atividades de cunho educativo, social e de orientações sobre os direitos, quais seriam as contribuições dos psicólogos e a melhor forma de integração com os outros profissionais e serviços.

Cabe ressaltar que a assistência específica para situações de violência só tem sentido porque o fenômeno é freqüente e não é reconhecido como violência pelos profissionais em geral e pela população. Se os direitos estivessem garantidos na prática, no acesso aos serviços e no atendimento respeitoso que levasse em consideração os direitos, e a ética nas relações interpessoais não haveria necessidade de serviços específicos como as DEAMs e os centros de referência, por exemplo. Estes serviços são recursos importantes para a mudança cultural na direção da equidade de gênero na sociedade, que não se restringe a promover assistência, mas almeja relações mais eqüitativas em todos os âmbitos sociais.

Com relação à capacitação e supervisão dos profissionais dos serviços voltados para violência contra as mulheres, nos documentos normativos não havia definição de profissionais específicos para a realização das capacitações e supervisões, mas nos centros de referência e abrigos que desenvolviam estas atividades, os psicólogos estavam entre os responsáveis por elas. Tanto nos documentos como nos serviços estudados, as capacitações e supervisões visavam aperfeiçoar o trabalho assistencial, atentando para o conhecimento sobre as 
particularidades das situações de violência de gênero, doméstica e/ou intrafamiliar, e também para a reflexão sobre os papéis de gênero, discussões de casos, acolhimento do impacto emocional, angústias e dificuldades no trato com as situações de violência atendidas. Concordou-se com os documentos normativos, de que este não seria um trabalho específico e exclusivo deste profissional, sendo imprescindível ter conhecimento e experiência no tema. Mas lembrou-se que os psicólogos poderiam contribuir com a condução destas atividades de formação, especialmente a supervisão, já que na sua formação clínica desenvolvem recursos para lidar com o sofrimento emocional da sua clientela e para distinguir e trabalhar com os afetos implicados na relação terapêutica. Especificamente para as situações de violência de gênero, viu-se que a capacitação e supervisão consistiam na discussão sobre a dinâmica das relações familiares/ conjugais violentas, a reflexão e consciência das próprias concepções e valores de gênero. A clareza dos profissionais em geral sobre seus valores e concepções possibilitaria maior domínio da técnica assistencial, evitando-se perder a dimensão ética e moral da relação assistencial.

Compartilhar o saber teórico e prático com a equipe poderia ser um dos elementos específicos do trabalho do psicólogo com a violência. Isto efetivaria o apoio entre a equipe não só no que diz respeito à solidariedade no trabalho e nas decisões conjuntas, mas também nos aspectos técnicos da intervenção. Neste sentido, valeria para todos os profissionais, cada um compartilhando, nos espaços de capacitação e supervisão, o que teria de específico na sua formação para a construção de um saber comum a respeito da violência de gênero, o que facilitaria e incrementaria o trabalho de equipe e a assistência a essas situações de violência. 


\section{REFERÊNCIAS BIBLIOGRÁFICAS}

Acosta, F; Barker, G. Homens, violência de gênero e saúde sexual e reprodutiva: um estudo sobre homens no Rio de Janeiro/ Brasil. Instituto Promundo e Instituto Noos, 2003.

Alves, AM; Coura-Filho, P. Avaliação das ações de atenção às mulheres sob violência no espaço familiar, atendidas no Centro de Apoio à Mulher (Belo Horizonte), entre 1996 e 1998. Ciência \& Saúde Coletiva, 2001, vol.6, n. 1, pp.24357.

Antunes, MAM (org). História da psicologia no Brasil - primeiros ensaios. Rio de Janeiro: Ed. UERJ: Conselho Federal de Psicologia, 2004. Araújo, MF. Atendimento a mulheres e famílias vítimas de violência doméstica. Perfil. Revista de Psicologia. (Assis), 1996, vol. 9, p. 5-15

Araújo, MF; Mattioli, OC (orgs). Gênero e violência. Arte e Ciência, São Paulo, 2004.

Barbieri, T de. Sobre a categoria gênero: uma introdução teórico-metodologica. SOS Corpo, Recife, 1993.

Barsted, LAL. Violência contra a Mulher e Cidadania: uma avaliação das políticas públicas. Cadernos Cepia, Rio de Janeiro, 1994.

Batliwala, S. The meaning of women's empowerment: new concepts from action. In: Population Policies reconsidered: health, empowerment, and rights. Harvard Series on Population and International Health. Gita Sen; Adriene Germain; Lincoln C. Chen (editors), 1994.

Brandão, ER. Nos corredores de uma delegacia da mulher: um estudo etnográfico sobre as mulheres e a violência conjugal. Instituto de Medicina Social da Universidade Estadual do Rio de Janeiro. [dissertação]. Rio de Janeiro, 1997.

Brandão, E. Violência conjugal e o recurso feminino à policia. In: Bruschini, C. e Hollanda, HB (orgs) Horizontes Plurais. São Paulo, Fundação Carlos Chagas/ Ed. 34, 1999. 
Butler, J. Variações sobre sexo e gênero. Beauvoir, Wittig e Foucault. In: Benhabib, S.; Cornell, D. Feminismo como critica da modernidade. Rosa dos Tempos, Rio de Janeiro, 1987, p.139-54.

Cabrejos, MEB (coord). Violencia intrafamiliar - los caminos de las mujeres que rompieron el silencio. Un estudio cualitativo de la ruta critica que siguen las mujeres afectadas por la violencia intrafamiliar. OPAS, Peru, 1998.

Campos, CH. Juizados Especiais Criminais e seu déficit teórico. Revista Estudos Feministas, 2003, v.11, n.1, pp.155-70.

Carone, I. A Psicologia tem paradigmas? Casa do Psicólogo, São Paulo, Fapesp 2003.

Coimbra, CMB. Guardiães da ordem. Uma viagem pelas praticas psi no Brasil do "milagre". Oficina do autor, Rio de Janeiro, 1995.

Coimbra, CMB. Violência do estado e violência "doméstica": o que têm em comum? In: Rauter, C; Passos, E; Benevides, R. (orgs) Clínica e política - subjetividade e violação dos Direitos Humanos. Equipe clínico-grupal, Grupo Tortura Nunca Mais RJ. Instituto Franco Basaglia/ Ed. TeCorá. Rio de Janeiro, 2002, pp.77-88.

Couto, MT; Schraiber, LB. Homens, saúde e violência: novas questões de gênero no campo da saúde coletiva. In: Minayo, MCS; Coimbra Junior, CEA. Críticas e atuantes: ciências sociais e humanas em saúde na América Latina. Rio de Janeiro: Ed. Fiocruz, 2005, pp.687-706.

Dantas-Berger, SM; Giffin, K. A violência nas relações de conjugalidade: invisibilidade e banalização da violência sexual? Cadernos de Saúde Pública, marabr 2005, 21(2), pp. 417-25.

D’Oliveira, AFPL. Violência de gênero, necessidades de saúde e uso de serviços em atenção primária. [tese], Faculdade de Medicina da Universidade de São Paulo, São Paulo, 2000.

D’Oliveira, AFPL; Schraiber, LB. Identificando possibilidades e limites do trabalho em rede para a redução da violência contra a mulher: estudo entre três capitais brasileiras. Relatório de pesquisa. Ministério da Justiça/ SENASP, abril de 2006. 
Ellsberg, M. (coord) Como atender a las mujeres que viven situaciones de violencia domestica? Nicarágua, Red de Mujeres contra la Violencia/ Departamento de Medicina Preventiva y Salud Publica de la Facultad de Medicina UNAN-Leon, 1998. Figueiredo, LCM. Matrizes do pensamento psicológico. Vozes, Petrópolis, 1991.

Garcia, S. Conhecer os homens a partir do gênero e para além do gênero. In: Arilha, M; Unbehaum, S; Medrado, B (orgs). Homens e Masculinidades: outras palavras. Ecos/ Ed. 34, São Paulo, 1998, pp.31-50.

Gregrori, MF. Cenas e queixas: um estudo sobre mulheres, relações violentas e a prática feminista. Paz e Terra, Rio de Janeiro; ANPOCS, São Paulo, 1993.

Gregori, MF. Delegacias de Defesa da Mulher de São Paulo e instituições: paradoxos e paralelismos. In: Debert, GG et al. Gênero e distribuição da Justiça: as Delegacias de Defesa da Mulher e a construção das diferenças. Núcleo de Estudos de Gênero Pagu/ Unicamp, Campinas, 2006.

Gonzaga, MTC; Oliveira, ASLV; Russo, DM; Yoshimato, G; Oliveira, KB; Simm, LA. Compromisso com a construção da cidadania da mulher: setor de psicologia da Delegacia da Mulher de Maringá, Paraná - Brasil. Psicologia em Estudo, Maringá, 1999, vol.4, n.3, pp. 211-7.

Heise, L. Violence against women. An integrated, ecological framework. Violence Against Women, june 1998, vol.4, n.3, pp. 262-290.

Heise, L; Ellsberg, M; Gottemoeller, M. Ending violence against women. Population Reports, December 1999, vol. XXVII, n.4.

Kahhale, EMP (org). A diversidade da psicologia: uma construção teórica. Cortez, São Paulo, 2002.

Kiss, L. Temas médico-sociais e a intervenção em saúde: a violência contra mulheres no discurso dos profissionais. [dissertação], Faculdade de Medicina USP, Medicina Preventiva, 2004.

Kiss, L.; Schraiber, LB; D’Oliveira, AFPL. Possibilidades de uma rede intersetorial de atendimento a mulheres em situação de violência. Interface - Comunicação, Saúde, Educação. 2007. ISSN 1414-3283. ISSN online 1807-5762. 2007.

Machado, LZ. Eficácia e desafios das delegacias especiaiizadas no atendimento às mulheres: o futuro dos direitos à não violência. In: CNDM, Relatório final da 
pesquisa nacional sobre as condições de funcionamento das delegacias especializadas no atendimento às mulheres. 2002. Disponível em http://www.cfemea.org.br/temasedados/detalhes.asp?IDTemasDados=1

Machado, MRC. Narrativa de mulheres vítimas de violência: passos do processo. Psicologia, Teoria e Pratica. Universidade Presbiteriana Mackenzie, jan/jun, 2004, vol. 6, n. 1, pp. 97-104.

Marteleto, MR. Análise de redes sociais - aplicação nos estudos de transferência da informação. Ci. Inf. (Brasília), jan/abr, 2001, v.30, n.1, pp.71-81.

Marteleto, MR; Silva, ABO. Redes e capital social: o enfoque da informação para o desenvolvimento local. Ci. Inf. (Brasília), set/dez, 2004, v.33, pp.41-49.

Medrado, B.; Lyra, J. Nos Homens, A Violência de Gênero. In: Secretaria Especial de Políticas para as Mulheres (Brasil). Programa de prevenção, assistência e combate à violência contra a mulher - plano nacional: diálogos sobre violência doméstica e de gênero: construindo políticas públicas / Secretaria Especial de Políticas para as Mulheres, 2003, pp.21-6.

Mendes-Gonçalves, RB. Práticas de saúde: processos de trabalho e necessidades. Cadernos CEFOR, Série Textos 1, Centro de Formação dos Trabalhadores em Saúde da Secretaria Municipal da Saúde (CEFOR/SMS), São Paulo. 1992.

Mendes-Gonçalves, RB. Tecnologia e organização social das práticas de saúde. Hucitec/ Abrasco, São Paulo, 1994.

Meneghel, SN; Camargo, M; Fasolo, LR; Mattiello, DA; Silva, RCR; Santos, TCB; Dagord, AL; Reck, A; Zanetti, L; Sottili, M; Teixeira, MA. Mulheres cuidando de mulheres: um estudo sobre a Casa de Apoio Viva Maria, Porto Alegre, Rio Grande do Sul, Brasil. Cadernos de Saúde Pública, set 2000, vol.16, n.3, p.747-57.

Ministério da Saúde. Secretaria de Políticas Públicas de Saúde. Violência intrafamiliar: orientações para prática em serviço. Série Cadernos de Atenção Básica nº8. Brasília: Ministério da Saúde, 2001.

Ministério da Saúde. Secretaria de Atenção à Saúde. Departamento de Ações Programáticas Estratégicas. Área Técnica de Saúde da Mulher. Prevenção $e$ tratamento dos agravos resultantes da violência sexual contra mulheres $e$ 
adolescentes: norma técnica. $2^{\mathrm{a}}$ ed. atualizada e ampliada. - Brasília: Ministério da Saúde, 2005a.

Ministério da Saúde. Atenção humanizada ao abortamento: norma técnica. Ministério da Saúde, Secretaria de Atenção à Saúde, Departamento de Ações Programáticas Estratégicas - Brasília: Ministério da Saúde, 2005b.

Mulheres em Situação de Violência: guia prático de serviços: município de São Paulo, 2002. São Paulo: Coletivo Feminista Sexualidade e Saúde - CFSS e Centro de Saúde Escola S. B. Pessoa, Depto. de Medicina Preventiva da Faculdade de Medicina da USP. $3^{\text {a }}$ ed. (revista e ampliada), 2002.

Muszkat, ME (org.) Mediação de conflitos - pacificando e prevenindo a violência. Summus, São Paulo, 2003.

Muszkat, ME. Violência de gênero e paternidade. In: Arilha, M; Unbehaum, S; Medrado, B (orgs). Homens e masculinidades: outras palavras. Ecos/ Ed. 34, São Paulo, 1998.

Organização Mundial de Saúde. Relatório mundial sobre violência e saúde. Editado por Etienne G. Krug e outros, Genebra, 2002.

Organización Panamericana de la Salud. Redes o coaliciones de acción en violencia intrafamiliar. Programa Mujer, Salud y Desarrolo. Serie Género y Salud Publica. San Jose, Costa Rica, 1999.

Pedrosa, CM. Mulheres em situação de violência: o discurso dos profissionais de saúde. [dissertação] Programa de Psicologia Social PUC-SP, 2003.

Peduzzi, M. Equipe multiprofissional de saúde: a interface entre trabalho e interação. [tese] Faculdade de Ciências Médicas da Unicamp, Campinas, 1998.

Peduzzi, M. Equipe multiprofissional de saúde: conceito e tipologia. Revista de Saúde Pública, 2001, 35(1), pp. 103-9.

Rede de Serviços - assistência a mulheres e adolescentes em situação de violência. Município de São Paulo. Ministério da Justiça e FMUSP, São Paulo, 2005.

Reichenheim, ME; Moraes, CL; Szklo, A; Hasselmann, MH; Souza, ER; Lozana, JA; Figueiredo, V. The magnitude of intimate partner violence in Brazil: portraits from 
15 capital cities and Federal District. Cadernos de Saúde Pública. Rio de Janeiro, fev, 2006, 22 (2), pp.425-37.

Rodriguez, ACR; Vizzotto, MM. Uma experiência de plantão psicológico numa Delegacia de Defesa da Mulher. Psicólogo Informação. 1998/1999, ano 2/3, no 2/3, pp. 39-68.

Sagot, M. Ruta crítica de las mujeres afectadas por la violencia intrafamiliar en América Latina (estudios de caso de diez países). Organización Panamericana de la Salud/ Programa Mujer, Salud y Desarrollo, 2000.

Schmidt, MLS. Ecletismo e dogmatismo na adesão às teorias psicológicas. Interações: Estudos e pesquisas em Psicologia, jan/jun, 1999, vol IV, n.7, pp.19-41.

Schraiber, LB. Medicina tecnológica e prática profissional contemporânea: novos desafios, outros dilemas. [livre-docência]. Universidade de São Paulo, Medicina Preventiva, 1997.

Schraiber, LB. Violência contras as mulheres e políticas de saúde no Brasil: o que podem fazer os serviços de saúde? Revista USP, set/nov 2001, n.51, pp.104-13.

Schraiber, LB; D’Oliveira, AFPL. O que devem saber os profissionais de saúde para promover os direitos e a saúde das mulheres em situação de violência doméstica. Coletivo Feminista Sexualidade e Saúde, Depto Medicina Preventiva Faculdade de Medicina USP, 2002a.

Schraiber, LB; D’Oliveira, AF (coord). Violência contra a mulher e saúde no brasil - estudo multipaíses da OMS sobre saúde da mulher e violência doméstica. (Relatório de pesquisa). Depto de Medicina Preventiva da Faculdade de Medicina da Universidade de São Paulo e Organização Mundial da Saúde. 2002b.

Schraiber, LB; D’Oliveira, AFPL; Couto, MT. Violência em interface com a saúde: contribuições teóricas, metodológicas e éticas com base em estudos da violência contra a mulher. Cadernos de Saúde Pública. [submetido 2007].

Schraiber, LB; D’Oliveira, AFPL; Falcão, MTC; Figueiredo, WS. Violência dói e não é direito: a violência contra a mulher, a saúde e os direitos humanos. Unesp, São Paulo, 2005a. 
Schraiber, LB; D’Oliveira, AFPL; França-Junior, I; Pinho, A. Violência contra a mulher: estudo em uma unidade de atenção primária à saúde. Revista de Saúde Pública, 2002, 36(4): pp.470-7.

Schraiber, LB; D’Oliveira, AF; Hanada, H; Figueiredo, W; Couto, M; Kiss, L; Durand, J; Pinho, A. Violência vivida: a dor que não tem nome. Interface Comunicação, Saúde, Educação, 2003, v.7, n. 12, pp.41-54.

Schraiber, LB; Gomes, R; Couto, MT. Homens e saúde na pauta da saúde coletiva. Ciência e Saúde Coletiva, 2005b, 10 (1): 7-17.

Scott, J. Gênero: uma categoria útil para análise histórica. Recife, 1991. Tradução. (mimeo). Texto original: Gender: na category of historical anlyses. Gender and the politics of history. New York, Columbia University Press, 1989.

Secretaria Especial de Políticas para as Mulheres (Brasil). Programa de prevenção, assistência e combate à violência contra a mulher - Plano Nacional: diálogos sobre violência doméstica e de gênero: construindo políticas públicas / Secretaria Especial de Políticas para as Mulheres. - Brasília, 2003.

Secretaria Especial de Políticas para as Mulheres (Brasil). Plano Nacional de Políticas para as Mulheres - Relatório de Implementação - 2005, Brasília, 2006c.

Secretaria Especial de Políticas para as Mulheres e Secretaria Nacional de Segurança Pública (Brasil). Norma técnica de padronização - delegacias especializadas de atendimento à mulher - DEAMs. Brasília, 2006a.

Secretaria Especial de Políticas para as Mulheres (Brasil). Norma técnica de uniformização - Centros de referência de atendimento a mulher em situação de violência. Brasília, 2006b.

Silva, KC. As DEAMs, as corporações policiais e a violência contra as mulheres: representações, dilemas e desafios. In: CNDM, Relatório final da Pesquisa Nacional sobre as Condições de Funcionamento das Delegacias Especializadas no Atendimento às Mulheres. 2002.

Souza, CM e Adesse, L (org). Violência sexual no Brasil: perspectivas e desafios. Secretaria Especial de Políticas para as Mulheres, Brasília, 2005.

Vagostello, L; Pavanelli, THL; Tardivo, LC. A Sala de espera enquanto espaço terapêutico: uma experiência com mulheres vítimas de violência. In: Tardivo, LSPC; 
Gil, CA e col. Anais Jornada Apoiar: propostas de atendimento. Laboratório de Saúde Mental e Psicologia Clínica Social. Instituto de Psicologia da Universidade de São Paulo. São Paulo, 2003.

Verardo, T. Do amor ao ódio. In: D’Oliveira, AFPL (org). Coletânea de textos do Curso de Capacitação para o Atendimento a Mulheres em situação de violência. Departamento de medicina Preventiva/ FMUSP, Coletivo Feminista Sexualidade e Saúde, 1998a, pp.25-31. (artigo publicado originalmente na revista Presença da Mulher, seção Direito, 1993, jan-fev-mar, pp. 30-2).

Verardo, T. Violência. In: D’Oliveira, AFPL (org). Coletânea de textos do Curso de Capacitação para o Atendimento a Mulheres em situação de violência. Departamento de medicina Preventiva/ FMUSP, Coletivo Feminista Sexualidade e Saúde, 1998b, pp.19-24. (artigo publicado originalmente na revista Presença da Mulher, seção Direito, 1993, jan-fev-mar, pp.08-10).

Willians, LCA; Gallo, AE; Maldonado, DA, Basso, AFT. Psicologia para policiais da delegacia da mulher: um relato de experiência. Psicologia: Teoria e Prática, 2000, 2(2), pp. 103-19. 
Anexo A 


\section{APROVACÃO}

A Comissão de Ética para Análise de Projetos de Pesquisa - CAPPesq da Diretoria Clínica do Hospital das Clínicas e da Faculdade de Medicina da Universidade de São Paulo, em sessão de 13.10.04, APROVOU o Protocolo de Pesquisa $n^{\circ}$ 779/04, intitulado: "Identificando possibilidades e limites do trabalho em rede para a redução da violência contra a mulher: estudo em três capitais brasileiras" apresentado pelo Departamento de MEDICINA PREVENTIVA, inclusive o Termo de Consentimento Livre e Esclarecido.

$$
\text { Cabe ao pesquisador elaborar e apresentar à }
$$

CAPPesq, os relatórios parciais e final sobre a pesquisa (Resolução do Conselho Nacional de Saúde $n^{\circ} 196$, de 10.10.1996, inciso IX.2, letra " $c^{\prime \prime}$ ).

Pesquisador(a) Responsável: Profa. Dra. Ana Flávia Pires Lucas d'Oliveira

CAPPesq, 13 de Outubro de 2004.

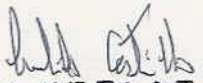

PROF. DR. EUCLIDES AYRES DE CASTILHO Presidente da Comissão de Ética para Análise de Projetos de Pesquisa 
Anexo B 


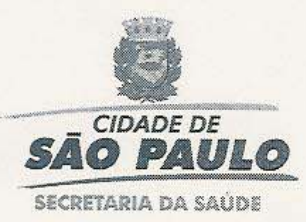

Prefeitura do Município de São Paulo Secretaria Municipal da Saúde Coordenação de Desenvolvimento da Gestão Descentralizada - COGest Comitê de Ética em Pesquisa

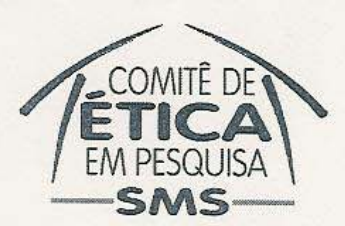

São Paulo, 02 de Setembro de 2005.

\section{PARECER N0105/2005 - CEPSMS}

Prezado (a) Senhor (a),

Pelo presente, informo que o Comitê de Ética em Pesquisa da Secretária Municipal de Saúde de São Paulo analisou, e APROVOU, de acordo com a Resolução CNS 196/96, o protocolo de pesquisa "Indentificando possibilidades e limites do trabalho em rede para a redução da violência contra a mulher: estudo em três capitais brasileiras.- CAAE 0050/05, de autoria do(a) pesquisador(a) Äna Flavia Pires Lucas d'Oliveira.

Como procedimento adotado por este Comitê de Ética em Pesquisa, solicitamos a inclusão, no Termo de Consentimento Livre e Esclarecido do seguinte: qualquer questão, dúvida, esclarecimento ou reclamação sobre os aspectos éticos dessa pesquisa, favor entrar em contato com: Comitê de Ética em Pesquisas da Secretaria Municipal da Saúde de Säo Paulo - Rua General Jardim, $36-2^{\circ}$ andar Telefone: 3218-4043-e-mail: smscep@prefeitura.sp.gov.br.

Lembramos que este parecer não basta para que seu estudo possa se realizar dentro da unidade, é necessária também a permissão administrativa da autoridade sanitária.

Salientamos os seguintes aspectos a serem considerados pelo pesquisador:

- O sujeito da pesquisa tem a liberdade de recusar-se a participar ou de retirar seu consentimento em qualquer fase da pesquisa, sem penalização alguma ou sem prejuízo ao seu cuidado (Res. CNS 196/96 - item IV.11) e deve receber uma cópia do Termo de Consentimento livre e esclarecido, na íntegra, por ele assinado (item IV.2.d)

- O pesquisador deve desenvolver a pesquisa conforme delineada no protocolo aprovado. Eventuais modificações ou emendas ao protocolo devem ser apresentadas ao CEP de forma clara e sucinta, identificando a parte do protocolo a ser modificada e suas justificativas. O relatório final deve ser apresentado ao CEP, logo que o estudo estiver concluído.

Atenciosamente,

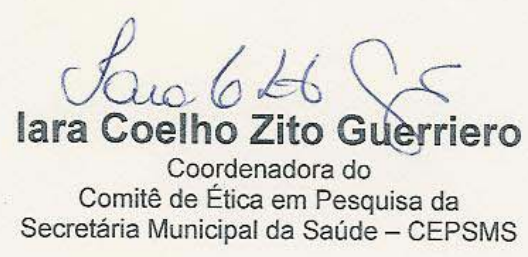

IImo(a). Sr(a).

Ana Flávia P Luasc

Rua General Jardim, $36-2^{\circ}$ andar - Vila Buarque - São Paulo, SP - CEP 01223-010 Telefone: (11) 3218-4043 e-mail: smscep@prefeitura.sp.gov.br homepage: http://portal.prefeitura.sp.gov.br/secretarias/saude/organizacao/cepsms/ 
Anexo C 


\section{CONSENTIMENTO INFORMADO}

Eu, abaixo assinado, concordo em conceder entrevista para esta pesquisa que trata das Possibilidades e limites do trabalho em rede para a redução da violência contra a mulher: estudo em três capitais brasileiras. Entendo que os dados fornecidos serão divulgados em formato de Guia de Serviços para instituições e população em geral. Fui informado(a) que os dados a serem divulgados serão previamente submetidos à minha consulta prévia para autorização de disseminação.

Entendo que minhas respostas serão importantes para apoiar o desenvolvimento do trabalho em rede intersetorial de serviços para a atenção a meninas e mulheres em situação de violência doméstica.

São Paulo, de de 2005

Assinatura Entrevistada

Recebimento:

Assinatura Pesquisadora

Obs. Se você tiver dúvidas sobre essa pesquisa sinta-se à vontade para perguntar agora ou à coordenação geral ( Dra. Ana Flávia Pires Lucas d'Oliveira e Dra. Lilia Blima Schraiber, telefone: 3066 7085) 
Anexo D 


\section{CONSENTIMENTO INFORMADO}

Eu, abaixo assinado, concordo em conceder entrevista para esta pesquisa que trata das Possibilidades e limites do trabalho em rede para a redução da violência contra a mulher: estudo em três capitais brasileiras. Entendo que os dados fornecidos serão divulgados em formato de Guia de Serviços para instituições e população em geral. Fui informado(a) que os dados a serem divulgados serão previamente submetidos à minha consulta prévia para autorização de disseminação.

Entendo que minhas respostas serão importantes para apoiar o desenvolvimento do trabalho em rede intersetorial de serviços para a atenção a meninas e mulheres em situação de violência doméstica.

São Paulo, de de 2005

Assinatura Entrevistada

Recebimento:

Assinatura Pesquisadora

Obs. Se você tiver dúvidas sobre essa pesquisa sinta-se à vontade para perguntar agora ou à coordenação geral (Dra. Ana Flávia Pires Lucas d'Oliveira e Dra. Lilia Blima Schraiber, telefone: 3066 7085)

E qualquer questão, dúvida, esclarecimento ou reclamação sobre os aspectos éticos dessa pesquisa, favor entrar em contat com: Comitê de Ética em Pesquisas da Secretaria Municipal da Saúde de São Paulo. R. Gal. Jardim, 36, $2^{\circ}$ andar, telefone: 3218.4043, email smscep@prefeitura.sp.gov.br. 
ANEXo E 


\title{
UNIVERSIDADE DE SÃO PAULO
}

FACULDADE DE MEDICINA

\author{
DEPTo DE MED. PREV./CENTRO DE SAÚDE ESCOLA \\ SOS CORPO INSTITUTO FEMINISTA PARA A DEMOCRACIA \\ THEMIS
}

\begin{abstract}
Pesquisa "Identificando possibilidades e limites do trabalho em rede para a redução da violência contra a mulher: estudo em três capitais brasileiras"
\end{abstract}

Profas. responsáveis:

Ana Flávia D’Oliveira e Lilia Blima Schraiber 


\section{PARTE I}

\section{GERENTE}

\section{1- IDENTIFICAÇÃO}

1.1 - Nome da Instituição (Razão Social):

1.2 - Nome do/a entrevistado/a:

1.3 - Cargo/função que ocupa e tempo de trabalho na instituição:

1.4 - Endereço:

No.

Comp:

CEP Bairro

Cidade

Tel: (011) Fax:

e-mail:

Ponto de referência:

1.5 - Período de atendimento:

Durante a semana:

Final de semana:

Sábado:

Domingo:

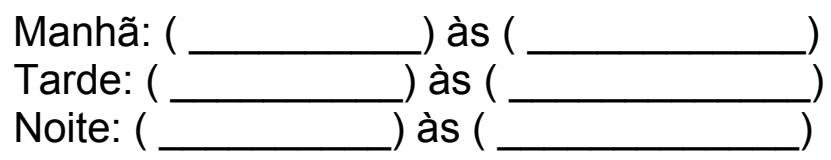

Manhã:

Tarde:

Noite:

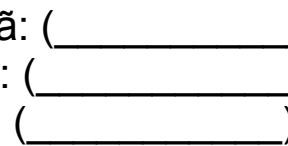

) às (

Manhã:

Tarde:

Noite:

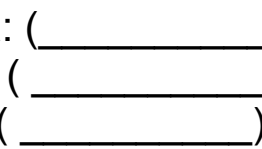
às

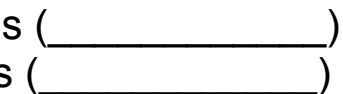

1.6 - A instituição é de caráter:

( ) Governamental

( ) Federal

( ) Estadual

( ) Municipal

Especifique também a Secretaria a que está vinculada:

( ) Não governamental

1.7 - Tempo de existência do programa/serviço:

2. QUAL(IS) OS OBJETIVO(S) DA INSTITUIÇÃO? (precisar como o entrevistado delimita o problema para o qual o serviço está voltado, sua finalidade) 


\section{3- CARACTERIZAÇÃO DA CLIENTELA ATENDIDA}

3.1 A instituição atende a:

3.1.a.
( ) crianças
( ) adolescentes
( ) adultos
( ) idosos

3.1.b.

( ) de ambos os sexos

( ) somente mulheres

3.2 A instituição trabalha com área de abrangência? Em caso positivo especifique a área e razões de sua delimitação.

3.3 Volume (conforme dados disponíveis). Tentar conseguir informações que estimem volume mensal de atendimentos e/ou de usuárias(os) do serviço voltado para violência.

\begin{tabular}{|l|l|l|l|}
\hline Atendimentos/Tipo & No/mês & Usuárias(os) & No/mês \\
\hline & & & \\
\hline & & & \\
\hline & & & \\
\hline & & & \\
\hline & & & \\
\hline & & & \\
\hline
\end{tabular}

Se a instituição atender também homens, anotar proporção entre mulheres e homens atendidos:

3.4 - Origem da clientela

( ) Espontânea Quantidade (estime a proporção):

Como ficam sabendo da existência do serviço?

( ) Encaminhada Quantidade (estime a proporção): 
Especifique 3 lugares que mais encaminham para o seu serviço (por ordem de volume de encaminhamento/freqüência):

\begin{tabular}{|l|l|l|l|l|}
\hline Instituições & $\begin{array}{l}\text { O que fazem estas } \\
\text { instituições } \\
\text { (referente à situação de } \\
\text { violência contra mulher)? }\end{array}$ & $\begin{array}{l}\text { Você conhece alguém } \\
\text { destas instituições? De } \\
\text { que forma? }\end{array}$ & $\begin{array}{l}\text { O que você acha que ela } \\
\text { deveria fazer? }\end{array}$ & $\begin{array}{l}\text { Como avalia a } \\
\text { adequação do } \\
\text { encaminhamento? }\end{array}$ \\
\hline 1. & & & & \\
\hline 2. & & & & \\
\hline 3. & & & & \\
\hline 4. Outras & & & & \\
\hline
\end{tabular}




\section{RECURSOS HUMANOS}

\begin{tabular}{|l|l|l|l|}
\hline $\begin{array}{l}\text { Referente aos } \\
\text { funcionários que } \\
\text { trabalham na } \\
\text { instituição }\end{array}$ & Quantidade & Função & $\begin{array}{l}\text { Tempo de } \\
\text { dedicação } \\
\text { semanal }\end{array}$ \\
\hline Administrativos & & & \\
\hline Serviços gerais & & & \\
\hline $\begin{array}{l}\text { Coordenação } \\
\text { Técnicos (nível e } \\
\text { formação): }\end{array}$ & & & \\
\hline $\begin{array}{l}\text { Técnicos (nível e } \\
\text { formação): }\end{array}$ & & & \\
\hline $\begin{array}{l}\text { Técnicos (nível e } \\
\text { formação): }\end{array}$ & & & \\
\hline formação): & & & \\
\hline Outros: & & & \\
\hline & & & \\
\hline
\end{tabular}

4.1 - Descreva a estruturação da equipe (chefias, grupos de trabalho, etc.) 


\section{ATIVIDADES DESENVOLVIDAS}

5.1 - Descreva minuciosamente das atividades que o serviço realiza.

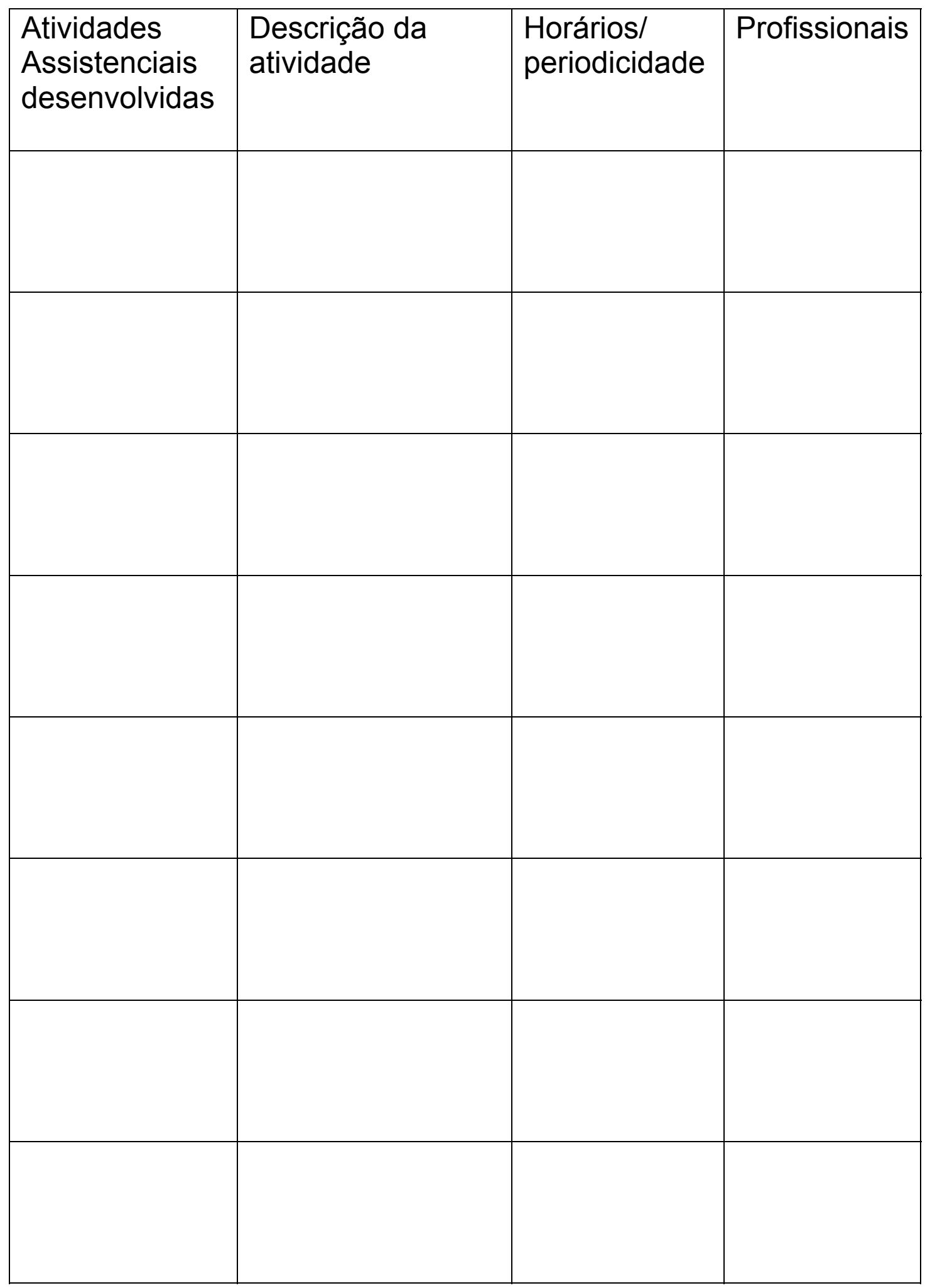


6 - INSERÇÃO NA REDE (assistência e informação)

\begin{tabular}{|l|l|l|l|l|}
\hline $\begin{array}{l}\text { 6.1 - A instituição faz } \\
\text { Encaminhamentos para } \\
\text { outras instituições? Cite 3 } \\
\text { ais utilizadas em ordem de } \\
\text { importância: }\end{array}$ & $\begin{array}{l}6.2 \text { - O que fazem estas } \\
\text { instituições? }\end{array}$ & $\begin{array}{l}6.3 \text { - Você conhece } \\
\text { alguém destas } \\
\text { instituições? De que } \\
\text { forma? }\end{array}$ & $\begin{array}{l}\text { 6.3 - Existe } \\
\text { avaliação/acompanhamento } \\
\text { destes encaminhamentos } \\
\text { realizados? }\end{array}$ & $\begin{array}{l}\text { 6.4 - O que você acha } \\
\text { que a instituição deveria } \\
\text { fazer? }\end{array}$ \\
\hline & & & & \\
\hline & & & & \\
& & & & \\
\end{tabular}


7.1 - Você já ouviu falar em rede intersetorial?

( ) sim ( ) não

Se sim, diga o quê?

7.2 - Você considera que o serviço atua em rede com as demais instituições? Por quê?

Quais? 


\section{PARTE II}

\section{PROFISSIONAL DA ASSISTÊNCIA}

\section{1 - IDENTIFICAÇAO:}

1.1 - Nome do entrevistado:

1.2 - Cargo/função que ocupa e tempo de trabalho no programa/serviço:

\section{2 - OBJETIVO DA INSTITUIÇÃO}

2.1. QUAL(IS) OS OBJETIVO(S) DA INSTITUIÇÃO? (precisar como o entrevistado delimita o problema para o qual o serviço está voltado)

\section{3- CARACTERIZAÇÃO DA CLIENTELA ATENDIDA}

3.1 Existe algum tipo de restrição para o atendimento dos clientes? Existe necessidade de apresentação de algum tipo de documento?

3.2 Para o Atendimento é necessário agendamento prévio ou a pessoa pode ser atendida na hora em que chega?

3.3 - Os clientes correspondem ao perfil esperado pelo serviço? Por quê? (caracterizar bem o perfil esperado)

3.4 - Origem da clientela

( ) Espontânea Quantidade (estime a proporção)

Como ficam sabendo da existência do serviço?
( ) Encaminhada
Quantidade (estime a proporção) 


\section{4- ENCAMINHAMENTO}

Especifique 3 lugares que mais encaminham para o seu serviço (por ordem de importância):

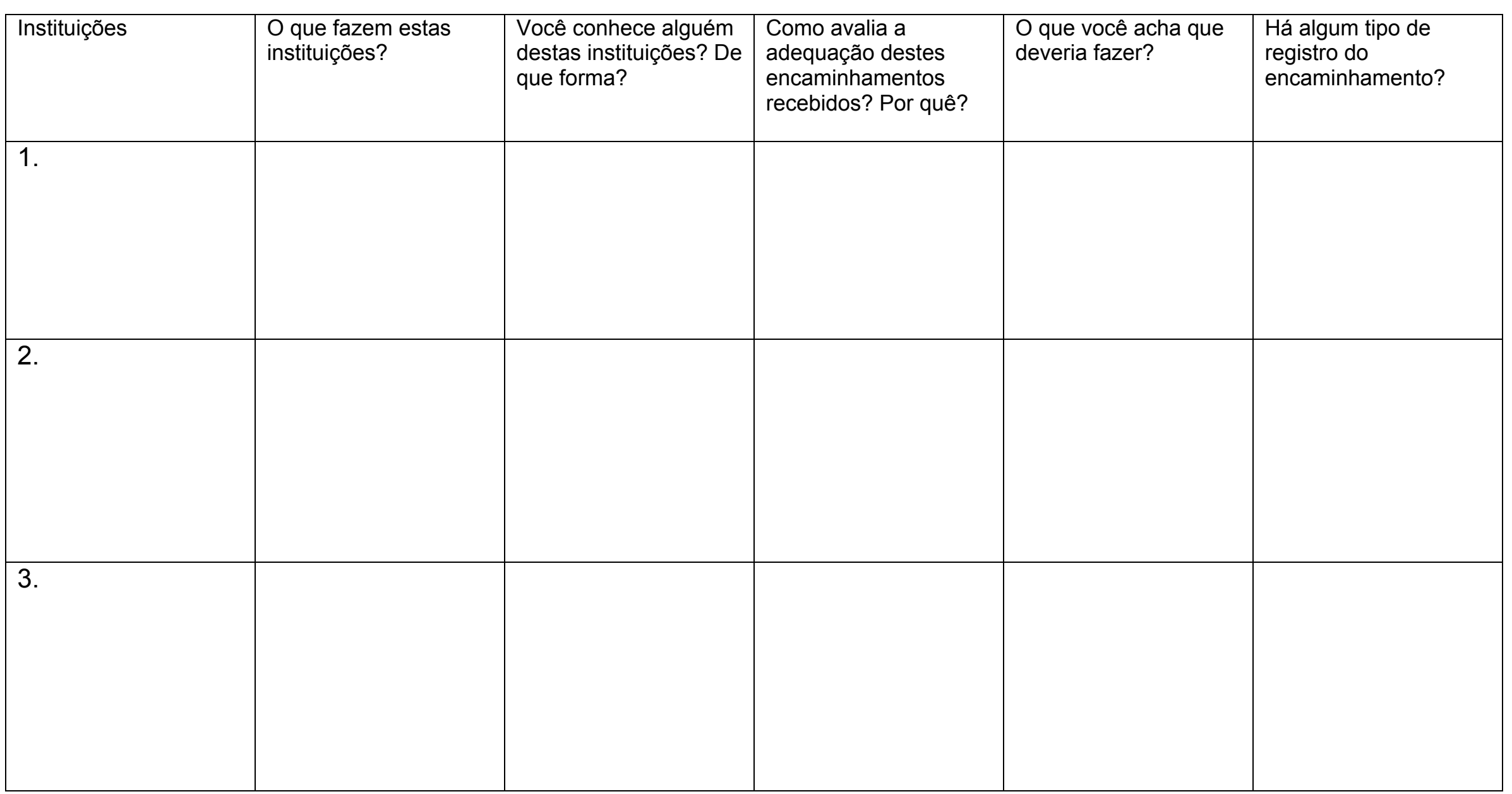


4.1 - Cite um exemplo de encaminhamento adequado realizado.

4.2 - Cite um exemplo de encaminhamento inadequado realizado.

\section{5 - ATIVIDADES DESENVOLVIDAS:}

5.1 - Fazer descrição minuciosa das atividades que o serviço realiza

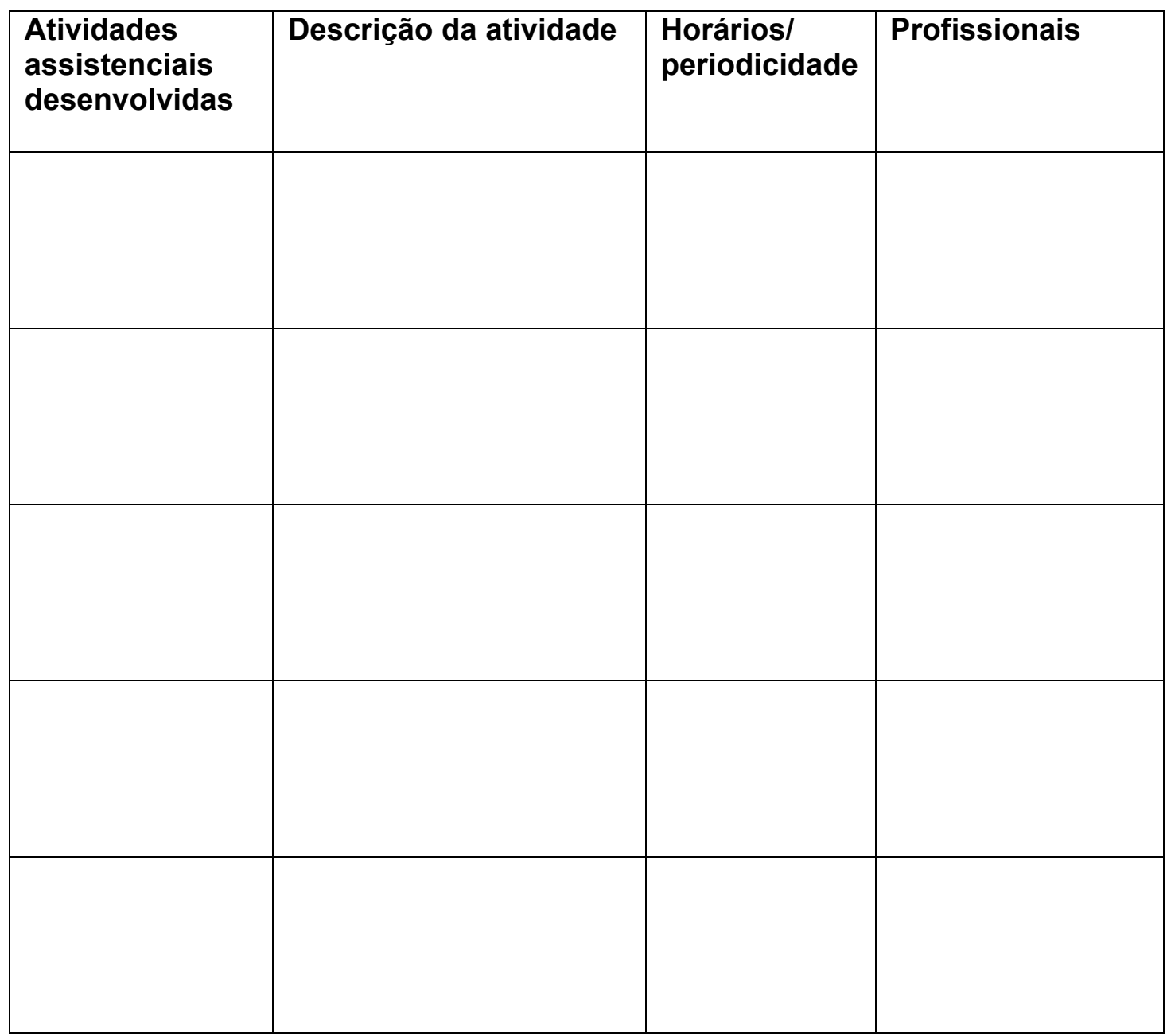


5.2 - Existe alguma atividade que você acha fundamental para o trabalho desta instituição, a qual ainda não existe? Por quê?

5.3 - Como é o Processo de Decisão? (quem faz o diagnóstico do problema, quem decide as condutas, na dúvida quem/como se decide etc).

Exemplificar com um caso típico e um atípico.

\section{4 - FLUXO ASSISTENCIAL}

Descrever quem recepciona, e o que vai acontecendo depois, passo a passo, até a saída da instituição - especificar rotinas de agendamento, alta e encaminhamentos. 
5.5 Existe reunião periódica da equipe?

5.6 Como você adquire e troca informações sobre o seu trabalho e o manejo dos casos?

5.7 Na sua opinião, como a clientela avalia o serviço? Especifique os fundamentos dessa opinião.

5.8 Existe avaliação sistemática das ações desenvolvidas? Em caso afirmativo, especifique. (mesmo se não há avaliação formal, verificar critérios que o profissional daria para a avaliação)

5.9. O que você acha que a sua instituição resolve nos casos atendidos? 
6- PRODUÇÃO INSTITUCIONAL (solicitar um exemplar do material)

6.1

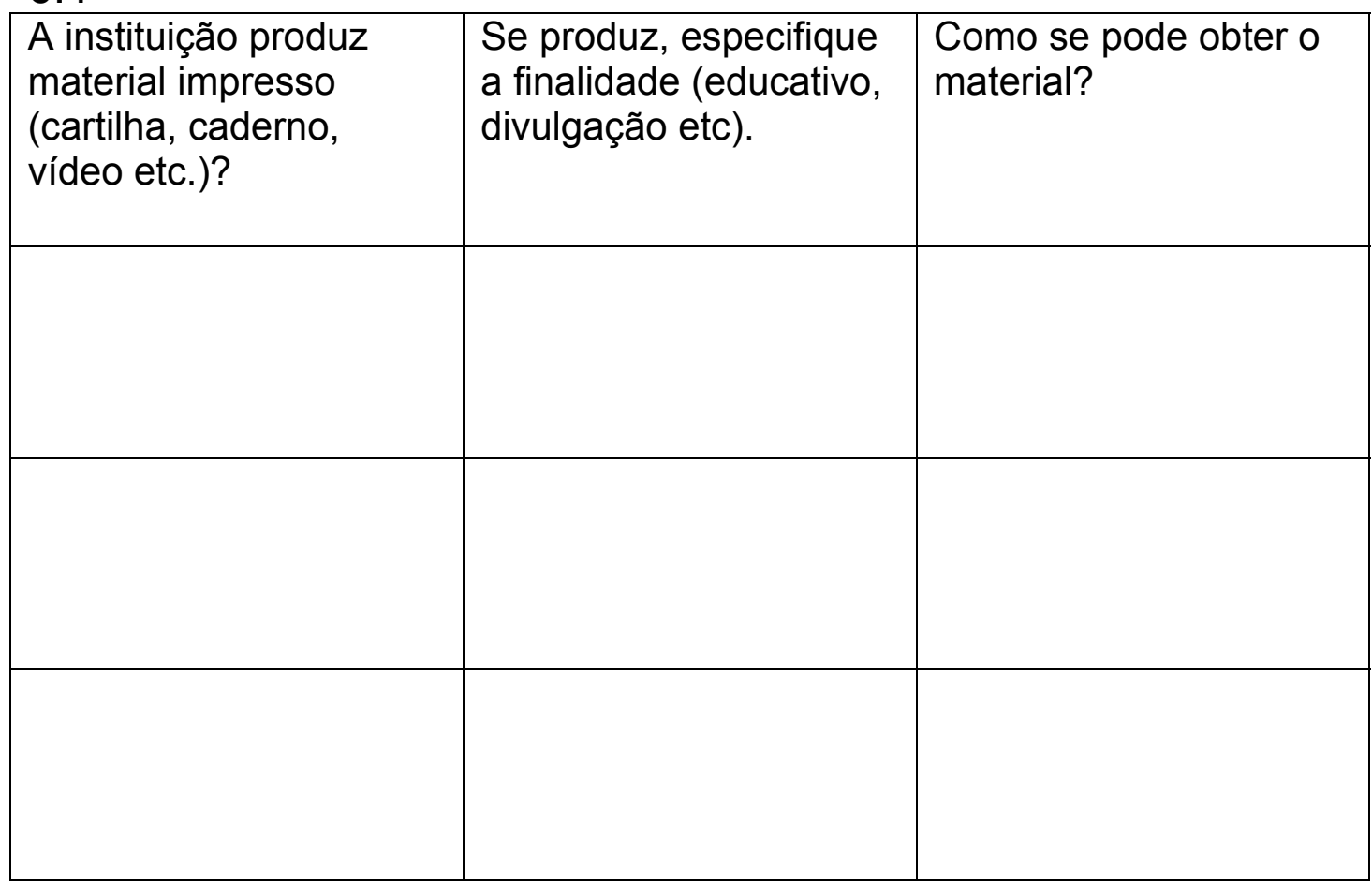

\section{2 - Materiais de Outras Instituições}

A instituição possui material impresso ou de vídeo sobre o tema violência?

\begin{tabular}{|l|l|}
\hline Vídeos: & Como utiliza? \\
\hline Cartilhas: & Como utiliza? \\
\hline Guias: & Como utiliza? \\
\hline Outros: & \\
\hline & Como utiliza? \\
\hline
\end{tabular}


7 - INSERÇÃO NA REDE (assistência e informação)

7.1 - A instituição Faz encaminhamentos para outras instituições? Cite 3 mais utilizadas em ordem de importância:

\begin{tabular}{|l|l|l|l|l|l|}
\hline Instituição & $\begin{array}{l}7.1 .1-\text { O que fazem estas } \\
\text { instituições? }\end{array}$ & $\begin{array}{l}7.1 .2-\text { Você } \\
\text { conhece alguém } \\
\text { destas instituções? } \\
\text { De que forma? }\end{array}$ & $\begin{array}{l}7.1 .3 \text { - Como avalia a } \\
\text { adequação destes } \\
\text { encaminhamentos } \\
\text { realizados? }\end{array}$ & $\begin{array}{l}7.1 .4-\text { O que você acha } \\
\text { que esta instituição } \\
\text { deveria fazer? }\end{array}$ & $\begin{array}{l}7.1 .5 \text { - Há registros } \\
\text { ou fichas de } \\
\text { encaminhamento? }\end{array}$ \\
\hline & & & & \\
\hline & & & & & \\
\hline
\end{tabular}


7.2 E como você adquire informações sobre os outros serviços e o que fazem?

7.3 - O que você acha da rede de instituições existentes para o trabalho com violência? Que tipo de serviços faltam para complementar o seu trabalho? Por quê?

7.4 - Existe algum tipo de reunião periódica com outras instituições de sua região? Especifique:

7.5 - Você já ouviu falar em rede intersetorial?
( ) sim
( ) não

Se sim, diga o quê?

7.6 - Você considera que o serviço atua em rede com as demais instituições? Por quê?

Quais? 
7.7 - Agora vou citar alguns tipos de instituição que atendem mulheres e meninas em situação de violência e gostaria de saber quais delas você conhece.

\begin{tabular}{|c|c|c|c|c|c|c|c|c|c|c|c|c|}
\hline INSTITUIÇÕES & $\begin{array}{l}7.7 .1 \\
\text { Conhece este } \\
\text { serviço? } \\
\text { Qual? }\end{array}$ & & $\begin{array}{l}\text { Po } \\
\text { ma }\end{array}$ & & $\begin{array}{l}7.7 . \\
\text { enc } \\
\text { ent }\end{array}$ & $\begin{array}{l}\operatorname{Rec} \\
\min \\
?\end{array}$ & & $\begin{array}{l}7.7 \\
\text { Enc } \\
\text { me } \\
\text { est } \\
\text { ins }\end{array}$ & $\begin{array}{l}\text { Faz } \\
\text { amin } \\
\text { to pa } \\
\text { tuiça }\end{array}$ & & $\begin{array}{l}\text { 7.7.5 Qual o } \\
\text { tipo de } \\
\text { serviço } \\
\text { prestado pela } \\
\text { instituição? }\end{array}$ & $\begin{array}{l}7.7 .60 \text { que } \\
\text { acha que esta } \\
\text { Instituição } \\
\text { resolve? Por } \\
\text { quê? }\end{array}$ \\
\hline & & + & ++ & +++ & + & ++ & +++ & + & ++ & +++ & & \\
\hline Delegacia & & & & & & & & & & & & \\
\hline Delegacia da Mulher & & & & & & & & & & & & \\
\hline $\begin{array}{l}\text { Orientação } \\
\text { Jurídica/Assistência }\end{array}$ & & & & & & & & & & & & \\
\hline $\begin{array}{l}\text { Centros Referência } \\
\text { da Mulher }\end{array}$ & & & & & & & & & & & & \\
\hline $\begin{array}{l}\text { Assistência } \\
\text { Psicológica }\end{array}$ & & & & & & & & & & & & \\
\hline
\end{tabular}




\begin{tabular}{|c|c|c|c|c|c|c|c|c|c|c|c|c|}
\hline \multirow[t]{2}{*}{ INSTITUIÇÕES } & \multirow[t]{2}{*}{$\begin{array}{l}7.7 .1 \\
\text { Conhece este } \\
\text { serviço? } \\
\text { Qual? }\end{array}$} & \multicolumn{3}{|c|}{$\begin{array}{l}\text { 7.7.2 Possui } \\
\text { informação? }\end{array}$} & \multicolumn{3}{|c|}{$\begin{array}{l}\text { 7.7.3 Recebe } \\
\text { encaminham } \\
\text { ento? }\end{array}$} & \multicolumn{3}{|c|}{$\begin{array}{l}\text { 7.7.4 Faz } \\
\text { Encaminha } \\
\text { mento para } \\
\text { esta } \\
\text { instituição? }\end{array}$} & \multirow[t]{2}{*}{$\begin{array}{l}\text { 7.7.5 Qual o } \\
\text { tipo de serviço } \\
\text { prestado pela } \\
\text { instituição? }\end{array}$} & \multirow[t]{2}{*}{$\begin{array}{l}7.7 .6 \text { O que } \\
\text { acha que esta } \\
\text { Instituição } \\
\text { resolve? Por } \\
\text { quê? }\end{array}$} \\
\hline & & + & ++ & +++ & + & ++ & +++ & + & ++ & +++ & & \\
\hline $\begin{array}{l}\text { Assistência Médi } \\
\text { e Psicossocial } \\
\text { Especializada }\end{array}$ & & & & & & & & & & & & \\
\hline $\begin{array}{l}\text { Serviço de Abort } \\
\text { Legal }\end{array}$ & & & & & & & & & & & & \\
\hline $\begin{array}{l}\text { Serviço de } \\
\text { Orientação } \\
\text { Telefônica }\end{array}$ & & & & & & & & & & & & \\
\hline $\begin{array}{l}\text { Outros Serviços } \\
\text { Especializados e } \\
\text { Violência (não só } \\
\text { mulher) }\end{array}$ & & & & & & & & & & & & \\
\hline Abrigos & & & & & & & & & & & & \\
\hline Outros & & & & & & & & & & & & \\
\hline
\end{tabular}


Anotações do/a Entrevistador/a:

Nome do Entrevistador:

Data da Entrevista: 